Hot Iherzolite exhumation, UHT migmatite formation, and acid volcanism driven by Miocene rollback of the Banda Arc, eastern Indonesia

Pownall, Jonathan M.

2017

Pownall , J M , Hall , R \& Armstrong , R A 2017 , ' Hot Iherzolite exhumation, UHT migmatite formation, and acid volcanism driven by Miocene rollback of the Banda Arc, eastern Indonesia ' , Gondwana Research , vol. 51 , pp. 92-117 . https://doi.org/10.1016/j.gr.2017.07.003

http://hdl.handle.net/10138/317208

https://doi.org/10.1016/j.gr.2017.07.003

cc_by_nc_nd

acceptedVersion

Downloaded from Helda, University of Helsinki institutional repository.

This is an electronic reprint of the original article.

This reprint may differ from the original in pagination and typographic detail.

Please cite the original version. 


\section{Accepted Manuscript}

Hot lherzolite exhumation, UHT migmatite formation, and acid volcanism driven by Miocene rollback of the Banda Arc, eastern Indonesia

Jonathan M. Pownall, Robert Hall, Richard A. Armstrong

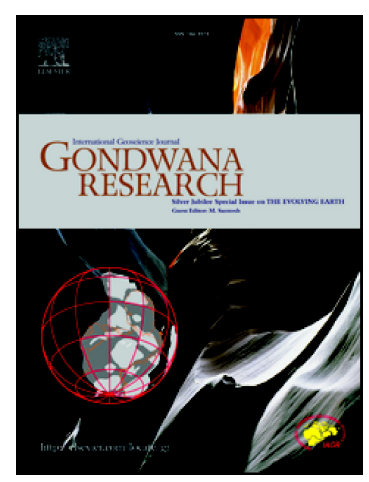

PII:

S1342-937X(16)30481-6

DOI: doi: $10.1016 /$ j.gr.2017.07.003

Reference:

GR 1838

To appear in:

Received date: $\quad 25$ January 2017

Revised date: $\quad 1$ June 2017

Accepted date: $\quad 9$ July 2017

Please cite this article as: Jonathan M. Pownall, Robert Hall, Richard A. Armstrong, Hot lherzolite exhumation, UHT migmatite formation, and acid volcanism driven by Miocene rollback of the Banda Arc, eastern Indonesia, (2016), doi: 10.1016/j.gr.2017.07.003

This is a PDF file of an unedited manuscript that has been accepted for publication. As a service to our customers we are providing this early version of the manuscript. The manuscript will undergo copyediting, typesetting, and review of the resulting proof before it is published in its final form. Please note that during the production process errors may be discovered which could affect the content, and all legal disclaimers that apply to the journal pertain. 


\title{
Hot lherzolite exhumation, UHT migmatite formation, and acid volcanism driven by Miocene rollback of the Banda Arc, eastern Indonesia
}

\author{
Jonathan M. Pownalla,b,*, Robert Halla, Richard A. Armstrongb
}

aSE Asia Research Group, Department of Earth Sciences, Royal Holloway University of London, Egham TW20 oEX, United Kingdom

${ }^{b}$ Research School of Earth Sciences, Australian National University, Canberra, ACT 2601, Australia

*Corresponding author (e-mail: jonathan.pownall@anu.edu.au)

\begin{abstract}
The northern Banda Arc, eastern Indonesia, exposes upper mantle/lower crustal complexes comprising lherzolites and granulite facies migmatites of the 'Kobipoto Complex'. Residual garnet-sillimanite granulites, which contain spinel + quartz inclusions within garnet, experienced ultrahigh-temperature (UHT; > $900^{\circ} \mathrm{C}$ ) conditions at $16 \mathrm{Ma}$ due to heat supplied by lherzolites exhumed during slab rollback in the Banda Arc. Here, we present $\mathrm{U}-\mathrm{Pb}$ zircon ages and new whole-rock geochemical analyses that document a protracted history of high- $T$ metamorphism, melting, and acid magmatism of a common sedimentary protolith. Detrital zircons from the Kobipoto Complex migmatites, with ages between 3.4 Ga and $216 \mathrm{Ma}$, show that their protolith was derived from both West Papua and the Archean of Western Australia, and that metamorphism of these rocks on Seram could not have occurred until the Late Triassic. Zircons within the granulites then experienced three subsequent episodes of growth - at 215-173 Ma, 25-20 Ma, and at c. $16 \mathrm{Ma}$. The population of zircon rims with ages between 215-173 Ma document significant metamorphic ( \pm partial melting) events that we attribute to subduction beneath the Bird's Head peninsula and Sula Spur, which occurred until the Banda and Argo continental blocks were rifted from the NW Australian margin of Gondwana in the Late Jurassic (from c. $160 \mathrm{Ma}$ ). Late Oligocene-Early Miocene collision between
\end{abstract}


Australia (the Sula Spur) and SE Asia (northern Sulawesi) was then recorded by crystallisation of several 25-20 Ma zircon rims. Thereafter, a large population of $c$. $16 \mathrm{Ma}$ zircon rims grew during subsequent and extensive Middle Miocene metamorphism and melting of the Kobipoto complex rocks beneath Seram under high- to ultrahigh-temperature (HT-UHT) conditions. Lherzolites located adjacent to the granulite-facies migmatites in central Seram equilibrated at $1280-1300^{\circ} \mathrm{C}$ upon their exhumation to $1 \mathrm{GPa}(\sim 37 \mathrm{~km})$ depth, whereupon they supplied sufficient heat to have metamorphosed adjacent Kobipoto Complex migmatites under UHT conditions at $16 \mathrm{Ma}$. Calculations suggesting slight ( 10 vol.\%) mantle melting are consistent with observations of minor gabbroic intrusions and scarce harzburgites. Subsequent extension during continued slab rollback exhumed both the lherzolites and adjacent granulite-facies migmatites beneath extensional detachment faults in western Seram at 6.0-5.5 Ma, and on Ambon at 3.5 Ma, as recorded by subsequent zircon growth and $40 \mathrm{Ar} / 39 \mathrm{Ar}$ ages in these regions. Ambonites, cordierite- and garnet-bearing dacites sourced predominantly from melts generated in the Kobipoto Complex migmatites, were later erupted on Ambon from 3.0-1.9 Ma.

\section{Introduction}

Convergence between Australia, SE Asia, and the Pacific has produced several long-lived, complexly-deformed subduction zones and orogenic belts throughout Indonesia, the Philippines, and Papua New Guinea (Hamilton, 1979; Hall and Wilson, 2000; Milsom, 2001; Hall, 2002, 2011, 2012, 2014; Hall and Spakman, 2002, 2015; Hinschberger et al., 2005; Harris, 2006, 2011; Richards et al., 2007; Spakman and Hall, 2010; Villeneuve et al., 2010; Watkinson and Hall, 2016). Eastern Indonesia (Fig. 1a), at the heart of this convergent zone, is a region of active subduction and volcanism incorporating young magmatic and metamorphic complexes that are preserved in their original tectonic settings (Honthaas et al., 1999; Kadarusman et al., 2010; Watkinson, 2011; Pownall et al., 2013, 2014, 2016, 2017; Advokaat et al., 2014; Ely et al., 2014; Hennig et al., 2014, 2016; White et al., 2014; Pownall, 2015; van Leeuwen et al., 2016). Within Eastern Indonesia, the Banda Arc-a continuation of the Sumatra-Java subduction system-incorporates both high temperature (Pownall et al., 2014; Pownall, 2015) and high pressure 
(Kadarusman et al., 2010; Ota and Kaneko, 2010) metamorphic rocks exhumed since the Miocene in response to rollback and subsequent collision of the Banda Arc with the Australian continental margin (Hamilton, 1979; Bowin et al., 1980; Spakman and Hall, 2010; Harris, 2011; Hall and Spakman, 2015; Pownall et al, 2016).

Southeastward rollback of the Banda slab (Hall, 2011) since $16 \mathrm{Ma}$ (Pownall et al., 2014) extended Australian continental lithosphere comprising the northern portion of the arc (the islands of Buru, Seram, and Ambon; Fig. 1b), exhuming subcontinental lithospheric mantle (Pownall et al., 2013, 2016, 2017) and driving (ultra-)high-temperature metamorphism (Pownall et al., 2014), melting (Priem et al., 1978; Pownall, 2015), and acid volcanism (Whitford and Jezek, 1979; Linthout et al., 1989, 1996; Honthaas et al., 1999).

The exhumed mantle lherzolites and parts of the 'Kobipoto Complex' migmatites in which UHT metamorphism occurred (Pownall, 2015) were then juxtaposed with rocks of the Tehoru Formation that existed at shallower structural levels. Parts of the Tehoru Formation-chlorite- to kyanite-grade metapelites and basic amphibolites that crop out over most of western and central Seram (Tjokrosapoetro \& Budhitrisna 1984; Pownall et al., 2013)-were in consequence overprinted by sillimanite-grade metamorphism, strongly sheared, and subject to localised partial melting (Pownall et al., 2013, 2017). These sillimanite-grade shear zones, classified now as parts of the Taunusa Complex, occur immediately above detachment faults that have facilitated high-temperature exhumation of granulitefacies migmatites and lherzolites of the lower-crustal-upper-mantle Kobipoto Complex.

Our recent 40Ar/39Ar study (Pownall et al., 2017) established a chronology of localised metamorphism and deformation of Tehoru Formation, Taunusa Complex, and Kobipoto Complex rocks on Seram. Here, we focus on the regional tectonic and geological implications of Kobipoto Complex metamorphism and melting. We present $\mathrm{U}-\mathrm{Pb}$ zircon ages for different members of the Kobipoto Complex, a thorough assessment of the different zircon age populations in the context of regional tectonics, whole-rock geochemical analyses of different members of the Kobipoto Complex, and the results of $\mathrm{Cpx}-\mathrm{Opx}$ thermometry for the lherzolites. Our aims are (i) to determine the youngest-recorded ages for multiple Kobipoto Complex diatexites across Seram and on Ambon; (ii) to investigate older ages recorded by zircon within the Kobipoto Complex in order to infer the Mesozoic history of the 
'basement' rocks of the Banda region; and (iii) to test the plausibility of our working hypothesis that that lherzolites were sufficiently hot to have metamorphosed adjacent crust under UHT conditions at c. $16 \mathrm{Ma}$, and that ambonites (cordierite + garnet dacites) present on Ambon were sourced from melts produced within the Kobipoto Complex.

\section{Geological context}

The densely rainforest islands of Seram and Ambon in the northern Banda Arc, eastern Indonesia (Fig. 1), expose migmatites and acid volcanic rocks with unusually high cordierite contents that are intimately associated with voluminous lherzolites. Early explorers named this region the 'cordierite province' (Schroeder van der Kolk, 1902), and cordierite + garnet dacites erupted on Ambon were considered sufficiently unusual to be named 'ambonites' after the island (Verbeek, 1905). Cordierite- and garnet-bearing leucosome-rich migmatites (diatexites), described previously as 'cordierite granites' (e.g. Priem et al., 1978), have been recognised for over a century as having a strong affinity with the ambonites; in addition to containing an abundance of cordierite and garnet, both rock types feature ubiquitous aluminous assemblages comprising sillimanite + hercynite spinel + cordierite (Martin, 1901; de Jong, 1923; Brouwer, 1925; Rittmann, 1931; Valk, 1945; van Bemmelen, 1949; Audley-Charles et al., 1979; Whitford and Jezek, 1979; Linthout et al., 1989; Honthaas et al., 1999; Pownall et al., 2013, 2014; Pownall, 2015). Unsurprisingly, there have been contrasting interpretations of these unusual 'cordierite granites' and ambonites, especially in regard to their origin and relationship with the ultramafic rocks.

Audley-Charles et al. (1979) suggested similarities between the geology of Seram (Fig. 1b) and that of Timor, and considered both islands to represent fold-andthrust belts that formed in response to arc-continent collision (see also Bowin et al., 1980; Jongsma et al., 1989; Hill, 2005). In accordance with this proposal, the ultramafic rocks were once interpreted as belonging to a large ophiolite, thrust northwards from the Banda Sea (Hutchison, 1976; Audley-Charles et al., 1979; Hamilton, 1979), which generated the 'cordierite granites' by obduction-induced anatexis within a metamorphic sole (Helmers et al., 1989; Linthout et al., 1989, 1991, 
1996, 1997; Linthout and Helmers, 1994; Sopaheluwakan, 1994; Monnier et al., 2003). The cordierite, garnet, and sillimanite + spinel assemblages were interpreted by Linthout and Helmers (1994) as restites left after partial melting of the metapelites and paragneisses comprising the sole, recording pressure-temperature $(P-T)$ conditions of $\sim 740^{\circ} \mathrm{C}$ and $4-5 \mathrm{kbar}$. However, our work has since questioned the 'Seram ophiolite' concept, and demonstrated that the ultramafic complex was instead exhumed from the subcontinental lithospheric mantle (SCLM) during an episode (or episodes) of extreme lithospheric extension (Hall and Wilson, 2000; Spakman and Hall, 2010; Hall, 2011, 2012; Pownall et al., 2013, 2014, 2016, 2017; Pownall, 2015).

In western Seram (Kaibobo and Hoamoal peninsulas), Kobipoto Complex migmatites and ultramafic rocks comprise the footwall beneath low-angle NNEdipping detachment faults (Fig. 2a). These detachments evidently operated at high temperature as adjacent to the fault, garnet-mica schists, phyllites, and amphibolites of the Tehoru Formation (originally defined by Audley-Charles et al., 1979) have been overprinted by $\sim 250 \mathrm{~m}$-thick zone of sillimanite-grade metamorphism, localized partial melting, and intensive mylonitisation immediately above the fault, forming the 'Taunusa Complex' (Tjokrosapoetro and Budhitrisna, 1982; Linthout et al., 1989, 1996; Pownall et al., 2013, 2017). Linthout et al. (1989) interpreted the Taunusa Complex as the metamorphic sole to their 'Seram ophiolite', whereas Pownall et al. (2013, 2017) interpreted it as the thermally overprinted and sheared hanging-wall above the exhumed Kobipoto Complex footwall. ${ }^{40} \mathrm{Ar} /{ }^{39} \mathrm{Ar}$ biotite ages of c. $5.5 \mathrm{Ma}$ for the mylonitised Taunsua Complex gneisses presented by both Linthout et al. (1996) and Pownall et al. (2017) provide very similar constraints on the timing of shear zone operation that we interpret to have facilitated the latest stage of mantle exhumation in western Seram.

The 'cordierite granites' present in western Seram and on Ambon were suggested by Pownall et al. (2013) to belong to the same granulite-facies migmatite complex as the garnet + cordierite + spinel + sillimanite granulites that crop out in the Kobipoto Mountains of central Seram (Pownall, 2015), and the Wai Leklekan Mountains of eastern Seram (Pownall et al., 2016). Highly residual Kobipoto Complex granulites in the Kobipoto Mountains were metamorphosed under ultrahigh-temperature (UHT) conditions of $\sim 925^{\circ} \mathrm{C}$ and $\sim 9$ kbar based on 
mineralogical evidence from coexisting spinel + quartz, supported by conventional thermobarometry and phase equilibria modelling (Pownall, 2015).

\section{Field relations and summary of previous work}

\subsection{Kobipoto Complex migmatites}

The Kobipoto Complex consists of peridotites and a granulite-facies migmatite complex comprising highly residual garnet + cordierite + sillimanite + spinel granulites (Fig. 4b), stromatic metatexites (Fig. 4d), and leucosome-rich granitic diatexites (Fig. 4c) previously described as 'cordierite granites' (migmatite terminology follows Sawyer, 2008). All rocks of the migmatite complex (and the ambonites), shown schematically in Figure 4, are characterised by garnet + cordierite + sillimanite + spinel $( \pm$ ilmenite \pm corundum $)$ bearing assemblages that represent the residual component. The 'cordierite granites' (Fig. 2b-f, 4c) are peppered with schlieren of sillimanite + spinel melanosome and sometimes schollen of metatexite in every instance we have observed (e.g., compare the Kobipoto Mountains [Fig. 2e] to Ambon [Fig. 2f]); for this reason, we favour the term 'cordierite diatexite' over 'cordierite granite' despite the voluminous leucosome having a granitic composition and granoblastic texture. There is no evidence that these rocks have migrated far from their source region; although scarce crosscutting aplite dykes demonstrate there has been at least some degree of melt mobilisation.

The cordierite diatexites are always separated from the ultramafic complex by a leucogranite carapace of variable thickness (100s of metres to 100 s of millimetres) characterised by granophyric K-feldspar-quartz symplectites, an absence of biotite and white mica, and the occurrence of titanite. The leucogranites have since intruded into both the (serpentinised) lherzolites and the cordierite diatexites that they separate (Fig. 2g-i). The contact between the leucogranites and the lherzolites, best exposed at Tanjung Seri on the south Latimor coast (cf. Hutchison, 1976; Pownall et al., 2013), demonstrates complex relationships showing intrusion of the leucogranite into the ultramafic complex was followed by a back-injection of later-stage (lower $T$ ) serpentinite veins into the leucogranite (Fig. Fig. 2h,i). As suggested by Linthout and Helmers (1994), these granophyric leucogranites likely represent a late-stage and low- 
pressure hypabyssal melt, which was evidently generated along the lherzolitediatexite interface.

The Kobipoto Mountains of central Seram represent a left-lateral pop-up structure that has exhumed Kobipoto Complex migmatites and lherzolites through overlying sedimentary successions (Pownall et al., 2013; Pownall and Hall, 2014) and exposes the residual granulites and metatexites that preserve evidence for UHT metamorphism at c. $16 \mathrm{Ma}$ (Pownall et al., 2014; Pownall, 2015). Similar diatexiteserpentinite contact relations to those exposed on Ambon are also seen in boulders in the Kobipoto Mountains (Fig. 2g). However, we could not find exposures of the original contact relations between the Kobipoto Complex and the associated Taunusa and Tehoru metamorphic complexes.

On Ambon, no part of the Tehoru Formation or Taunusa Complex is exposed, and the cordierite diatexites typically contain smaller and often scarcer sillimanite + spinel schlieren, although they remain a ubiquitous feature (Fig. 2f). Aplites, leucogranites, and evidence of limited magma mixing are also more abundant on Ambon, perhaps demonstrating more advanced stages of melt mobilisation and fractionation than the migmatites on Seram.

\subsection{Kobipoto Complex ultramafic rocks}

Exposures of peridotites occur across Latimor (S Ambon), on SW Hitu (N Ambon), across the Hoamoal and Kaibobo Peninsulas (W Seram), in the SE Wallace Mountains (SW Seram), as small bodies within the Kawa Shear Zone (central Seram), in the Kobipoto Mountains (central Seram), and in the Wai Leklekan Mountains in eastern Seram (Fig. 1b). As discussed above, these ultramafic rocks have previously been interpreted either as Asian-derived allochthonous thrust sheets (Audley-Charles et al., 1979), as young hot ophiolite ( 10 Myr old at time of obduction; Linthout and Helmers, 1994), or as exhumed hot sub-continental lithospheric mantle (Pownall et al., 2013).

Based on our observations, and those by Linthout and Helmers (1994), the peridotites are typically Cr-spinel-bearing lherzolites (Fig. 5), although the primary mineralogy is often obscured by later serpentinisation. Scarce gabbroic dykes, some several metres thick, have been observed within the peridotites, but no larger gabbroic bodies were found. Pillow basalts present on Tanjung Nusanive (SW 
Latimor) and on the island of Kelang (W of Seram), which have been dated at c. 2.7 Ma (Abbott and Chamalaun, 1981; Honthaas et al., 1999; see Table 1), appear to be unrelated to the exposed peridotites. Monnier et al. (2003) presented a geochemical study of the "weakly-depleted" 'Seram-Ambon ophiolites' and showed evidence for the subsolidus re-equilibration of many spinel lherzolites in the lower pressure plagioclase lherzolite/harzburgite field during their exhumation. The authors further suggested, albeit cautiously, that the occasional harzburgites present on Ambon and western Seram might have formed by metasomatic alteration of the lherzolites without the need for extensive partial melting, which could account for the relative scarcity of basalts on Seram and Ambon. Unusually high $\mathrm{Th} / \mathrm{Nb}$ ratios were explained by Monnier et al. (2003) as requiring the peridotites to have formed adjacent to continental crust, and high $\mathrm{Cr} \#(\mathrm{Cr} /[\mathrm{Cr}+\mathrm{Al}])$ values were used as evidence in support of the undepleted residual nature of the peridotites. The authors also identified websterites with adakitic geochemical signatures, suggesting derivation from a deep garnet peridotite or eclogitic source, potentially from within the underlying slab (cf. Defant and Drummond, 1990). Phlogopite-rich lamprophyres that we observed intruding lherzolites in the Kobipoto Mountains (see Fig. 7 of Pownall et al., 2017) also require a deep mantle melt source, as perhaps do ijolites described from central Seram by Germeraad (1946). Lastly, it should be noted that large positive gravity anomalies reported by Milsom (1977) and Milsom et al. (2001) require huge thicknesses of dense ultramafic rocks beneath western Seram and Ambon. We argue that the features listed above all support an exhumed SCLM origin-not an ophiolitic origin-for the Seram and Ambon peridotites.

\subsection{Ambonites}

The ambonites, emplaced across Ambon and the southernmost tip of the Hoamoal Peninsula, have long been recognised as atypical volcanic products exclusive to the two Plio-Pleistocene volcanoes on Hitu, northern Ambon (Verbeek, 1905; Brouwer, 1925; Kuenen, 1949). They contain abundant cordierite and garnet xenocrysts (Fig. 3c, 5h) and small gneissose sillimanite + spinel xenoliths (Fig. 5i) in addition to scarce xenoliths of cordierite diatexites (Fig. 3b). These features, which resemble those of the El Hoyazo dacites of the Betic Cordillera (Zeck, 1970; Zeck and Williams, 2002), led van Bemmelen (1949) to propose the ambonites were sourced 
predominantly from the same crustal melt as the cordierite diatexites. Subsequent authors have argued for a purely anatectic origin for the ambonites (Magaritz et al., 1978; Whitford and Jezek, 1979, 1982), although others maintain that a small additional mantle-derived component is required (Honthaas et al., 1999). In contrast, according to the 'Seram ophiolite' hypothesis, the ambonites were produced by the mixing of obduction-generated cordierite-rich granitic magmas with basaltic/andesitic melts that ascended through crustal-scale transform faults (Linthout and Helmers, 1994).

The ambonites, which are high-K dacites, are geochemically distinct from the low-K suite of basalts and basaltic andesites typical of the Banda Arc (Jezek and Hutchison, 1978; Whitford and Jezek, 1979; van Bergen et al., 1989; Vroon et al., 1993, 2001; Honthaas et al., 1999). Furthermore, many geochemical features of the ambonite lavas, namely (i) strong LILE and HFSE enrichment (Jezek and Hutchison, 1978; Whitford and Jezek, 1979; Honthaas et al., 1999), (ii) high ${ }^{87} \mathrm{Sr} /{ }^{86} \mathrm{Sr}$ ratios (Whitford et al., 1977; Magaritz et al., 1978; Whitford and Jezek, 1979, 1982), and (iii) high $\delta^{18} \mathrm{O}$ values (Magaritz et al., 1978; Vroon et al., 2001) are all explained by considerable assimilation of continental crust (as much as 80\%; Vroon et al., 2001). This geochemical evidence, and the presence of xenoliths of cordierite diatexite within the ambonites, strongly supports the inference of van Bemmelen (1949) that the lavas were predominantly sourced from the Kobipoto migmatite complex. In Section 5.1, we present an additional geochemical argument that further strengthens this interpretation.

\section{Sample petrography}

A suite of Kobipoto Complex cordierite diatexites were sampled from western and central Seram, and from Ambon, in order to investigate the variation in metamorphic histories, if any, across the region. A leucogranite and ambonite, both from Ambon, were also selected to extend this comparison. Sample locations are shown in Table 1 and Figure 1 b. 
This typical cordierite diatexite, sampled from the northern body of Kobipoto Complex migmatites on the Kaibobo Peninsula (Fig. 2b), contains abundant mmscale sillimanite- and spinel-bearing schlieren (Fig. 5a), in association with biotite. Cordierite is abundant, partially pinitised, and has white mica reaction rims. Garnet is scarce, plagioclase occurs as euhedral crystals, and K-feldspar is sector-zoned. Biotite from this sample has been dated at $5.9 \pm 0.1 \mathrm{Ma}(40 \mathrm{Ar} / 39 \mathrm{Ar}$ furnace step heating age; Pownall et al., 2017).

\subsection{KB11-336: Cordierite diatexite, Kaibobo Peninsula}

This cordierite diatexite, sampled in situ from an exposure next to the track leading from Kaibobo Village (Fig. 2c), has an abundant cordierite that forms square, blocky crystals with heavily chloritised margins (Fig. 5b). Sillimanite + spinel schlieren are less abundant than in SE10-178, but the grains of spinel that are present are larger; biotite is also coarser grained (Fig. 5b). Quartz, plagioclase, and K-feldspar form a coarse granoblastic texture around the cordierites.

\subsection{AB12-O26: Leucogranite, Latimor (Ambon)}

This sample was taken from a wide leucogranite body along the margin of a huge exposure of cordierite diatexites in central Latimor. As previously discussed, this lithology intrudes both the cordierite diatexites and the ultramafic complex. Euhedral plagioclase and K-feldspar crystals approaching $1 \mathrm{~cm}$ in length occur in a finely crystalline quartz groundmass (Fig. 5g). Some feldspars show granophyric intergrowths with quartz. Cordierite, garnet, sillimanite, spinel, and biotite are all absent, although relict titanite rhombs are present with alteration to chlorite (Fig. $4 \mathrm{~g})$.

\subsection{KP11-588, -619, and -621: Granulite-facies migmatites, Kobipoto Mountains}

These three samples, previously described and dated by Pownall et al. (2014), were sampled from the Wai Tuh river gorge in the Kobipoto Mountains, central Seram. KP11-588 (Fig. 4b), described in detail by Pownall (2015), is a residual granulite sample comprising garnet and prismatic sillimanite separated by complex 
reaction textures of cordierite + spinel + ilmenite + corundum \pm sapphirine (Fig. 5 e,f). Coexisting spinel + quartz preserved within garnet has been cited as evidence for UHT metamorphism (Pownall et al., 2014; Pownall, 2015). KP11-619 is notably more melanocratic than the 'typical' cordierite diatexite, and contains garnets surpassing $5 \mathrm{~mm}$ in diameter (Fig. $5 \mathrm{~d}$ ). Cordierite is also abundant ( $20 \mathrm{vol} \%$ ), albeit sometimes heavily pinitised, and is surrounded by biotite and mats of sillimanite + spinel. KP11-621 is more similar to the cordierite diatexites of western Seram and contains sub-mm garnets and fibrolitic sillimanite sprays within large partially pinitised cordierites (Fig. 5c).

\subsection{KP12-123: Lherzolite, Kobipoto Mountains}

This lherzolite was sampled in situ from an exposure in the Wai Sapolewa, Kobipoto Mountains, bordered either side by Kobipoto Complex granulites (see Fig. 16c of Pownall et al., 2013). Parts of the rock are unserpentinised and contain euhedral $2 \mathrm{~mm}$-long crystals of orthopyroxene and clinopyroxene separated by smaller granoblastic olivine crystals. Chrome spinels (magnesiochromites) are also present in low abundance. Whole-rock major- and trace-element abundances for KP12-123 are presented in Table 3, and mineral chemical data are presented in Table 4.

\subsection{AB12-384: Ambonite, Hitu (Ambon)}

This ambonite, sampled from a ravine in central-northern Hitu, contains abundant 1-5 mm diameter subhedral xenocrysts of cordierite and garnet (Fig. 3c, 5h). Biotite xenocrysts are also fairly abundant, with orthopyroxenes that contain small sprays of sillimanite. The $\mathrm{SiO}_{2}$-rich glassy groundmass contains acicular plagioclase laths in addition to smaller crystals of quartz. At the same locality, there are ambonites containing xenoliths of matted fibrolite + spinel (Fig. 5i).

\section{Origin of ambonites and Kobipoto Complex ultramafic rocks}


The purpose of this section is to test the plausibility of our working hypothesis that (i) the lherzolites were sufficiently hot to have metamorphosed adjacent crust under UHT conditions (as opposed to them being exhumed as cold, serpentinised mantle rocks akin to those present in hyperextended passive margins; e.g. Manatschal et al., 2015); and (ii) the ambonites (cordierite + garnet dacites) present on Ambon were sourced from melts produced within the Kobipoto Complex (as opposed to being 'conventional' island arc volcanic rocks).

\subsection{Derivation of ambonites from the Kobipoto Complex migmatites}

Major and trace element abundances for eleven Kobipoto Complex migmatite samples, two ambonite samples, and a leucogranite (Table 2) were determined from fused glasses and pressed-powder pellets, respectively, using a PANalytical Axios sequential wavelength-dispersive X-ray fluorescence spectrometer (XRF) fitted with a 4 kW Rh-anode X-ray tube at Royal Holloway University of London.

These trace element data are plotted relative to normal mid-ocean ridge basalt compositions (N-MORB; Sun and McDonough, 1989) in Figure 6. All profiles demonstrate broadly similar patterns, indicating a probable co-genetic relationship between different members of the Kobipoto Complex.

Most importantly, the normalised trace element abundances for the two ambonite samples (AB11-384 and SE10-8B) are very similar to those of the diatexites, strongly supporting inferences that the ambonites are sourced predominantly from melts sourced from the Kobipoto Complex migmatites (e.g., van Bemmelen, 1949; Magaritz et al., 1978; Whitford and Jezek, 1979, 1982; Honthaas et al., 1999; Vroon et al., 2001; Pownall et al., 2013). Although it is not impossible that this very large continental component may have been assimilated by low-volume low-K mafic magmas (Honthaas et al., 1999), the ambonites' strong affinity with the Kobipoto Complex migmatites demonstrates they are certainly not typical of 'arctype' lavas. We suggest the ambonites are the extrusive product of HT-UHT metamorphism and voluminous anatexis of metasedimentary rocks in the northern Banda Arc, generated far from the subduction-related volcanic arc located between Banda Api and Damar island (Fig. 1).

\subsection{Lherzolite Thermobarometry}


In order to evaluate the temperature of the SCLM during its juxtaposition with the Kobipoto Complex migmatites, and therefore test the hypothesis that mantle exhumation was the primary driver of HT-UHT metamorphism and melting on Seram, sample KP12-123, a chrome spinel-bearing lherzolite from the Kobipoto Mountains was selected for thermobarometry.

Major element mineral chemistry for sample KP12-123 (Table 4) was determined by analysis of a polished thin section using a JEOL JXA-8100 Superprobe electron microprobe (EMP) paired with an Oxford Instruments INCA EDS system at Birkbeck College, University of London. Analyses were performed using an accelerating voltage of $15 \mathrm{kV}$, a beam current of $10 \mathrm{nA}$, and a beam diameter of $1 \mu \mathrm{m}$. Calibration for all analyses was against standards of natural silicates and oxides, and a ZAF correction procedure was applied. $\mathrm{XFe}^{3+}\left(\mathrm{Fe}^{3+} / \mathrm{Fe}^{\text {total }}\right)$ for individual mineral analyses was calculated, based on charge balancing, using the program AX (Holland, 2016). Olivine $\left(\mathrm{Fo}_{90}\right)$, orthopyroxene $\left(\mathrm{En}_{90}\right)$, and clinopyroxene $\left(\mathrm{Di}_{95}\right)$ are accompanied by two populations of magnesiochromite at $\mathrm{Cr} \#_{20}$ and $\mathrm{Cr}_{53}$, respectively (Table 4). Whole-rock major- and trace-element abundances are presented in Table 3 .

Clinopyroxene-orthopyroxene $\mathrm{Ca}-\mathrm{Mg}$ exchange thermometers of Brey and Köhler (1990) and Taylor (1998), were applied to KP12-123 over a wide pressure range ( $0-3 \mathrm{GPa})$, as shown in Figure 7 . These thermometers yielded similar temperatures of $1250-1350^{\circ} \mathrm{C}$ over this investigated $P$ range, with the Taylor (1998) calibration suggesting slightly lower temperatures towards the lower $P$ end $\left(1289^{\circ} \mathrm{C}\right.$ at $1 \mathrm{GPa}$ ). Application of the enstatite-in-Cpx thermometer of Nimis and Taylor (2000) yielded significantly higher temperatures $\left(1350-1450^{\circ} \mathrm{C}\right)$, but this assumes that garnet was in equilibrium with the $\mathrm{Cpx}$-for which there is no evidence in the Kobipoto Complex lherzolites-suggesting this result is unreliable. Nimis and Grütter (2010) warned that the Brey and Köhler (1990) thermometer often overestimates $T$ towards lower $P$, as is compatible with our result, and we therefore favour the Taylor (1998) two-pyroxene thermometer which also provides the most conservative $T$ estimate.

Phase equilibria modelling of the Kobipoto Complex granulite sample KP11588 , sampled adjacent to lherzolites cropping out in the Kobipoto Mountains, yielded peak $P-T$ conditions of $925^{\circ} \mathrm{C}$ at $0.9 \mathrm{GPa}$ (Pownall, 2015). The lherzolites 
must therefore have equilibrated at similar $P$, and so sample KP12-123 most probably experienced maximum temperatures towards the lower end of the estimates shown in Figure $7-$ at $1280-1300^{\circ} \mathrm{C}$ in the vicinity of $1 \mathrm{GPa}$. Under these conditions, the lherzolite solidus is only marginally exceeded, producing $\sim 10$ vol.\% melting (following a study by Thompson and Gibson [2000] of a similar anhydrous lherzolite). This low modelled melt fraction is consistent with field observations for limited melting of the otherwise undepleted lherzolites; the relatively scarce occurrences of residual harzburgite and minor gabbroic intrusions (Monnier et al., 2003; Pownall et al., 2013) account for this 10 vol.\%.

\section{SHRIMP U-Pb zircon geochronology}

Previously published Miocene-Pleistocene $\mathrm{K}-\mathrm{Ar}$, ${ }^{40} \mathrm{Ar} / 39 \mathrm{Ar}, \mathrm{Rb}-\mathrm{Sr}$, and $\mathrm{U}-\mathrm{Pb}$ ages for the Kobipoto Complex migmatites, ambonites, and basalts of Seram, Ambon, and Kelang are shown in Table 1. Here, we present new SHRIMP U-Pb zircon ages for Kobipoto Complex diatexites, a leucogranite, and an ambonite to complement c. 16 Ma ages published by Pownall et al. (2014) for the Kobipoto Mountains samples that are interpreted to have dated UHT metamorphism on Seram.

\subsection{Analytical Methods}

Zircon grains were separated at Royal Holloway University of London from 63-250 $\mu \mathrm{m}$ diameter crushed rock fractions (from $>3 \mathrm{~kg}$ samples) using sodium polytungstate and diiodomethane heavy-liquid floatation, Frantz magnetic separation, and hand picking beneath a binocular microscope. The zircons from all four rocks were then arranged in strips on double-sided adhesive tape alongside Temora-II zircon standards (Black et al., 2004), and mounted in a single epoxy resin disk at the Research School of Earth Sciences (RSES), Australian National University (ANU), Canberra. The mount was then ground down and polished to expose a crosssection through the zircon grains, and then this polished surface was coated with gold (5 $\mathrm{nm}$ thickness). 
Cathodoluminescence (CL) images were acquired for all zircon grains at the RSES, ANU, using a Cameca SX-100 electron microprobe fitted with a CL hyperspectral imaging system. A representative selection of the CL images is shown in Figure 8; these images were essential in accurately positioning the analytical spot exclusively on the features (cores, rims, or other structures) of interest.

Analyses were performed by sensitive high-resolution ion microprobes SHRIMP-II and SHRIMP-RG (reverse geometry) over several analytical sessions at the RSES, ANU, according to procedures outlined in detail by Williams (1998). A 10 $\mathrm{kV}$ primary beam of $\mathrm{O}_{2}{ }^{-}$ions was focussed on the sample surface over a spot size that was adjusted between $\sim 10$ and $\sim 25 \mu$ m diameter between analytical sessions based on the requirement to target narrow or wide zircon rims. The area around the analytical spot was rastered with the ion beam for 120 seconds to remove surface contamination prior to analysis.

Analytical spots were selected when operating the SHRIMP based on matching by eye the CL images of the zircon grains to a 'live' reflected light image provided by a video camera mounted in the sample chamber. The zircon mount was re-photographed in reflected light after the analyses were complete in order to double-check if the analytical pits matched the intended part of the grain; in instances whereby the analytical pits were found to straddle two or more separate zircon features (thereby producing a mixed age) or the zircon grain and the epoxy resin (thereby producing an erroneous age), these results were not used in the age calculations.

Data were acquired by repeatedly stepping through the masses $90 \mathrm{Zr}_{2}{ }^{16} \mathrm{O}$ (“reference mass 196"), ${ }^{204} \mathrm{~Pb}$, background at mass $204.04,{ }^{206} \mathrm{~Pb},{ }^{207} \mathrm{~Pb},{ }^{208} \mathrm{~Pb},{ }^{23} 8 \mathrm{U}$, ${ }^{232} \mathrm{Th}$, and ${ }^{238} \mathrm{U}^{16} \mathrm{O}$ (mass 254) over a total of six runs per analytical spot, amounting to a $\sim 15$-minute duration analytical duration. Temora-II zircon standards $(416.8 \pm$ 0.3 Ma; Black et al., 2004) were used for calibration of the SHRIMP after every three analyses. The data were reduced using the SQUID-2 Excel macro (Ludwig, 2009) utilising decay constants from Steiger and Jäger (1977), and concordia diagrams were plotted using Isoplot-3 (Ludwig, 2003). Common $\mathrm{Pb}$ was corrected for Phanerozoic zircon by assuming ${ }^{206} \mathrm{~Pb} /{ }^{238} \mathrm{U}-207 \mathrm{~Pb} / 235 \mathrm{U}$ age concordance, and was corrected for Proterozoic and Archaean zircon using measured ${ }^{204} \mathrm{~Pb} /{ }^{206} \mathrm{~Pb}$ ratios. Ages are quoted at 95\% confidence and include the uncertainty in the standard where relevant. 


\subsection{Zircon classifications}

The following scheme was adopted to describe different parts of the zircon grains targeted by the analytical spots, as listed under the 'type' column of the supplementary data tables (see Appendix A):

- $\mathbf{R}_{\mathbf{m}}$ refers to either magmatic or metamorphic zircon rims (sample dependant).

- $\mathbf{C}_{\mathbf{m}}$ refers to either magmatic or metamorphic cores (sample dependant).

- $\mathbf{C}_{\mathbf{d}}$ refers to detrital zircon cores.

- $\quad \mathbf{R}_{\mathbf{2}}$ refers to a second CL-bright rim between $\mathrm{R}_{\mathrm{m}}$ rims and $\mathrm{C}_{\mathrm{d}}$ cores that are present in some grains.

- $\mathbf{R}_{\mathbf{o}}$ refers to very thin CL-bright overgrowths (that were too small to analyse).

- $\mathbf{X}$ refers to mixed analyses (between either two zircon zones or zircon and the epoxy resin) that have been discounted in subsequent age calculations.

These features are illustrated in Fig. 9.

\subsection{Zircon textures}

There are notable differences between the morphologies and textures of zircons formed within migmatites of the Kobipoto Complex and those that formed in the associated leucogranite and ambonite samples. As described for each sample in Appendix A, the Kobipoto Mountains zircons are characterised by (i) sector-zoned, oscillatory-zoned, or planar-banded $\mathrm{C}_{\mathrm{d}}$ detrital cores; (ii) wide weakly-zoned or homogeneously-luminescent $\mathrm{R}_{2}$ zones; (iii) wide CL-dark metamorphic $\mathrm{R}_{\mathrm{m}}$ rims; and (iv) very thin CL-bright $\mathrm{R}_{0}$ overgrowths (Fig. 8d-f, 9). Zircons from the Kaibobo Peninsula cordierite diatexites and the Latimor leucogranite lack the $\mathrm{R}_{2}$ zones and the $\mathrm{R}_{0}$ overgrowths and have $\mathrm{R}_{\mathrm{m}}$ rims with oscillatory zoning and higher $\mathrm{Th} / \mathrm{U}$ ratios (compare, e.g., KP11-619 Zircon Y and KB11-336 Zircon 1 in Fig. 9). Zircons from the ambonite are either purely magmatic $\left(\mathrm{C}_{\mathrm{m}}\right)$ or have very thick, prominently zoned, high-Th/U magmatic $\mathrm{R}_{\mathrm{m}}$ rims.

Cross-cutting relationships observable in the CL images of the Kobipoto Mountains zircons (e.g. KP11-588 Zircon 6, KP11-619 Zircon X, and KP11-619 Zircon 
$\mathrm{Y}$ in Fig. 9) demonstrate that: (i) the $\mathrm{R}_{2}$ zones formed, in part, by the recrystallisation of the zircon cores, demonstrated by homogeneously-luminescent $\mathrm{R}_{2}$ lobes that have transgressed older zircon and truncated zoning patterns within $\mathrm{C}_{\mathrm{d}}$ cores; (ii) some $\mathrm{R}_{2}$ zircon crystallised on the outside of the cores, as shown by parallel alignment of the zoning directions (e.g. KP11-588 Zircon 10, Fig. 9); (iii) $\mathrm{R}_{\mathrm{m}}$ zircon must (obviously) be younger than $\mathrm{R}_{2}$ zircon; (iv) $\mathrm{R}_{\mathrm{m}}$ zircon similarly formed, in part, by the alteration/recrystallisation of the zircon cores and $\mathrm{R}_{2}$ zones; $(v)$ the crystallisation of $\mathrm{R}_{\mathrm{m}}$ zircon within fractures running through the zircon cores and $\mathrm{R}_{2}$ zircon (e.g. KP11619 Zircon X, Fig. 9) shows that the zircons may have been fragmented, re-worked, and/or eroded between $\mathrm{R}_{2}$ and $\mathrm{R}_{\mathrm{m}}$ crystallisation; and (vi) $\mathrm{R}_{\mathrm{o}}$ zircon overgrowths are (obviously) younger than the $\mathrm{R}_{\mathrm{m}}$ rims, but did not affect every grain. Based on interpretation of these growth textures and CL responses (following Corfu et al., 2003; Taylor et al., 2016), most $C_{d}$ cores appear igneous in origin due to their prominent oscillatory zoning; $\mathrm{R}_{2}$ zones appear metamorphic, with the presence of dissolution fronts into the $\mathrm{C}_{d}$ cores demonstrating coexistence with a melt/fluid phase; and $R_{m}$ rims are typical of granulite-facies metamorphic zircon due to their low CL responses and featureless character.

Zircons from all three Kobipoto Mountains samples are texturally similar and record the same ages in both the residual granulite (KP11-588) and leucosome-rich diatexite (KP11-621), supporting the cogenetic relationship demonstrated among the samples (Fig. 7), and our field evidence for them belonging to the same granulitefacies migmatite complex.

Zircons from the western Seram samples are more straightforward to interpret, and comprise young magmatic rims crystallised around older detrital or magmatic cores. However, a few grains from sample SE10-178 display $\mathrm{R}_{2}$-like zones, revealed to have similar (although slightly older) ${ }^{206} \mathrm{~Pb} /{ }^{238} \mathrm{U}$ ages to $\mathrm{R}_{2}$ zircon from the Kobipoto Mountains samples. They quite possibly record the same event at $c$. $200 \mathrm{Ma}$, as discussed later.

\subsection{Zircon geochronology results}

Here we present a discussion of the corresponding $\mathrm{U}-\mathrm{Pb}$ ages for each of the seven samples (KP11-588, KP11-619, KP11-621, SE10-178, KB11-336, AB11-026, and AB11-384). U-Pb zircon SHRIMP geochronology results tables are presented in 
Appendix A; Tera-Wasserburg plots for each $\mathrm{R}_{\mathrm{m}}$ age are shown in Figure 10; Th/U plots are shown in Figure 11; concordia diagrams are shown in Figure 12; a plot of Late Triassic-Early Jurassic (215-173 Ma) ${ }^{206} \mathrm{~Pb} /{ }^{238} \mathrm{U}$ ages for $\mathrm{R}_{2}$ zircon is shown in Figure 13; histograms of detrital $\mathrm{C}_{\mathrm{d}}$ cores are show in Figure 14; and a summary of Neogene ages is presented in Figure 15.

A list of the weighted mean ${ }^{206} \mathrm{~Pb} / 238 \mathrm{U} \mathrm{R}_{\mathrm{m}}$ zircon ages for each sample is presented in Table 1 (and also shown in Fig. 10). Kobipoto Complex metatexites from the Kobipoto Mountains (prefixed 'KP11-'; published previously by Pownall et al., 2014) yielded $R_{m}$ ages of $16 \mathrm{Ma}$ and $\mathrm{R}_{2}$ ages between 176 and $210 \mathrm{Ma}$; diatexites from western Seram (SE10-178 and KB11-336) gave $\mathrm{R}_{\mathrm{m}}$ ages of $6.0-5.5 \mathrm{Ma}$; the leucogranite sample from Ambon (AB11-026) gave an $R_{m}$ age of $3.5 \mathrm{Ma}$; and the ambonite (AB11-384) was dated at $1.9 \mathrm{Ma}$. Note that many of these ages are identical-within-error to ${ }^{40} \mathrm{Ar} / 39 \mathrm{Ar}$ ages of biotite and white mica separated from the same samples, as reported by Pownall et al. (2017).

\subsubsection{SE1O-178: Kaibobo Peninsula cordierite diatexite}

Some grains separated from this diatexite are large, euhedral, and inclusionpoor, with oscillatory zoning; others show more complex zoning patterns, sometimes in radiating sectors, and have a more irregular grain morphology containing a higher number of inclusions (Fig. 8a). The grains are characterised by thin $\left(5^{-25} \mu \mathrm{m}\right) \mathrm{CL}-$ bright (U poor) zoned rims that show regular zoning patterns and occasionally have slightly embayed contacts with the zircon cores, commonly truncating their primary growth structures. The zircon cores are often well rounded, suggesting these cores are fragments of originally much larger grains. Rarely, wide homogeneouslyluminescent overgrowths are present, which show transgression into the cores these features have been categorised as $R_{2}$.

Twenty-five $\mathrm{U}-\mathrm{Pb}$ ages were determined for this sample. The zircon rims have consistent ${ }^{206} \mathrm{~Pb} /{ }^{238} \mathrm{U}$ ages of $6.0 \pm 0.2 \mathrm{Ma}$, shown by the Tera-Wasserburg plot in Fig. 10a. Th/U ratios of these rims (Fig. 11a) are fairly low $(<0.1)$, but not as low as for the metamorphic zircon rims present in the Kobipoto Mountains zircons. Zircon cores show a wide spread of ages between 1831 and $312 \mathrm{Ma}$ (Fig 12d). Two analysed medium-bright-CL overgrowths, assigned $\mathrm{R}_{2}$ status, give ${ }^{206} \mathrm{~Pb} /{ }^{238} \mathrm{U}$ ages of $222 \pm 5 \mathrm{Ma}$ and $271 \pm 4 \mathrm{Ma}$. Common $\mathrm{Pb}$ content for all analyses is low. 


\subsubsection{KB11-336: Kaibobo Peninsula cordierite diatexite}

Zircon grains separated from this diatexite are similar to those previously described for SE10-178, although they typically have thicker (5-35 $\mu \mathrm{m}$ ) CL-bright (U poor) zoned rims grown usually around the commonly sector-zoned cores (Fig. 8b). Again, the CL-bright rims show zoning patterns that are consistent with a magmatic origin, and occasionally have embayed contacts with the zircon cores, truncating core zoning patterns. Some rims display transgression into the core, resulting in a wavy, slightly lobate contact. Some zircon cores are well-rounded xenocrysts, but most, especially those exhibiting sector zoning, are euhedral and straight-sided crystals, with the youngest magmatic zircon rim also adopting this morphology (Fig. 8b and KB11-388 Zircon 1 in Fig. 9).

Twenty-one $\mathrm{U}-\mathrm{Pb}$ ages were determined for this sample. The zircon rims have consistent ${ }^{206} \mathrm{~Pb} /{ }^{238} \mathrm{U}$ ages of $5.5 \pm 0.2 \mathrm{Ma}$, shown by the Tera-Wasserburg plot in Fig. 9b. Th/U ratios of these rims (Fig. 11b) are not especially low (0.1-0.3), which is consistent with a magmatic origin. Zircon cores show a wide spread of ages between 1636 and $226 \mathrm{Ma}$ (Fig. 12e). Common Pb content for cores is low, but the \% ${ }^{206} \mathrm{~Pb}_{\mathrm{c}}$ for magmatic rims is notable (typically $3-8 \%$ ).

\subsubsection{Kobipoto Mountains migmatites}

Mean ${ }^{206} \mathrm{~Pb} /{ }^{238} \mathrm{U}$ ages of $15.8 \pm 0.3 \mathrm{Ma}, 16.0 \pm 0.6 \mathrm{Ma}$, and $16.3 \pm 0.3 \mathrm{Ma}$ for samples KP11-588, KP11-619, and KP11-621, respectively (see Table 1 and Fig. 10df), were reported by Pownall et al. (2014). These ages all relate to $>20 \mu \mathrm{m}$-thick CLdark (U rich) rims classified here as ' $\mathrm{R}_{\mathrm{m}}$ '. In addition, these outer CL-dark rims are separated from the cores by weakly-zoned highly-luminescent zones of similar thickness and morphology (e.g. KP11-588 Zircon 6 and 10 in Fig. 9) classified here as ' $R_{2}$ '. These $R_{2}$ zones display often severely embayed contacts with the zircon cores, with sharp transgressive fronts that form lobate structures in the cores, cross-cutting their primary zoning patterns (e.g. KP11-588 Zircon 6 in Fig. 9). The $\mathrm{R}_{\mathrm{m}}$ rims display similar relationships, and have overgrown, pervaded into, and cross-cut both the $\mathrm{R}_{2}$ zones and the cores. The zircon cores are either well rounded and display concentric zoning (albeit severely embayed) or are subhedral with highly-convolute zoning showing signs of metamictisation.

$\mathrm{Th} / \mathrm{U}$ ratios of these $\mathrm{R}_{\mathrm{m}}$ rims (Fig. 11d-f,h) are very low (most are $<0.02$ ), which is consistent with a metamorphic origin. Analyses of the the $\mathrm{R}_{2}$ zircon zones 
all give ${ }^{206} \mathrm{~Pb} /{ }^{238} \mathrm{U}$ ages around $200 \mathrm{Ma}$ (Fig. 13), and have distinctly higher $\mathrm{Th} / \mathrm{U}$ ratios of $\sim 0.1$ (Fig. 11h). Zircon cores show a wide spread of ages between 1565 and $262 \mathrm{Ma}$. Common $\mathrm{Pb}$ content for cores and $\mathrm{R}_{2}$ zones is low (<0.1\%), and is not especially high for the $\mathrm{R}_{\mathrm{m}}$ rims at $<5 \%$.

\subsubsection{AB11-026: Latimor (Ambon) leucogranite}

Zircon separated from this leucogranite are characterised by thick $(\sim 50 \mu \mathrm{m})$ concentrically-zoned rims grown around various types of weakly-zoned and complexly-zoned cores (Fig. 8c). Some zircon grains are acicular, suggesting a magmatic origin. The rims mostly have embayed contacts with the zircon cores that truncate core zoning patterns. The zircon cores are either well-rounded and xenocrystic, or are subhedral with sector or convolute zoning. Patches show complex alteration, possibly due to metamictisation. Some grains appear to be purely magmatic and do not contain visible cores in their exposed cross-section.

Twenty-six $\mathrm{U}-\mathrm{Pb}$ ages were determined for this sample. The zircon rims have consistent ${ }^{206 \mathrm{~Pb} /}{ }^{238} \mathrm{U}$ ages of $3.5 \pm 0.1 \mathrm{Ma}$, shown by the Tera-Wasserburg plot in Fig. 10c. Th/U ratios of these rims (Fig. 11c) are not especially low (most are $<0.2$, with some up to 0.55 ), which is consistent with a magmatic origin. Zircon cores show a wide spread of ages between 2397 and $248 \mathrm{Ma}$ (Fig. 12f). Common $\mathrm{Pb}$ content of the cores is low, but the $\%{ }^{206} \mathrm{~Pb}_{\mathrm{c}}$ for magmatic rims is typically $\sim 5 \%$, but sometimes up to $25 \%$.

\subsubsection{AB11-384: Hitu Ambonite}

Zircons separated from this ambonite are typically euhedral and free of inclusions, with several needle-like (purely magmatic) grains (Fig. 8g). Oscillatoryzoned magmatic rims $\left(\mathrm{R}_{\mathrm{m}}\right)$ are a feature of the vast majority of grains, and are often more voluminous than the detrital cores they enclose (e.g. AB11-384 Zircon 1 in Fig. 9); these $R_{m}$ rims define prismatic crystal habits. Some grains are purely magmatic (e.g. AB11-384 Zircon 7 in Fig. 9) and show simple zoning with clean, homogeneous regions, while other purely magmatic zircons show oscillatory zoning (Fig. 8g). Some rims have embayed contacts with the zircon cores, truncating core zoning patterns. These zircon cores are either well rounded and display concentric or sector zoning, or, as observed in most other samples, are subhedral with highly convolute zoning. 
Seventeen $\mathrm{U}-\mathrm{Pb}$ ages were determined for this sample. The $\mathrm{R}_{\mathrm{m}}$ zircon rims are very young, with consistent ${ }^{206} \mathrm{~Pb} / 238 \mathrm{U}$ ages of $1.9 \pm 0.2 \mathrm{Ma}$, shown by the TeraWasserburg plot in Fig. 10g. The Th/U ratios of these $\mathrm{R}_{\mathrm{m}}$ rims (Fig. $11 \mathrm{~g}$ ) mostly range between 0.1 and 0.5 , which is consistent with a magmatic origin. Zircon cores, of the few analyses taken, show a very wide spread of ages between 2547 and $246 \mathrm{Ma}$ (Fig. 12b). Common $\mathrm{Pb}$ content for cores is minimal (<0.1\%), but is very high (up to $45 \%$ ) for the $R_{m}$ rims, likely due to the young age of the zircon.

\subsection{Detrital zircon ages}

The detrital zircon cores show a very wide spread of $\mathrm{U}-\mathrm{Pb}$ ages between 3.4 Ga and $216 \mathrm{Ma}$ (Palaeoarchean to Early Jurassic). To further assess these ages, a histogram and relative probability plot for the combined detrital core $\left(\mathrm{C}_{\mathrm{d}}\right)$ population of all samples is shown in Fig. 14, created using an $R$ program (R Core Team, 2013) seazplot_v1ob1 (I. Sevastjanova, pers. comm., 2013) that uses plotrix (Lemon et al., 2013) and Hmisc (Harrell, 2013) packages. Note that Late Jurassic $C_{d}$-zircon ${ }^{206} \mathrm{~Pb} /{ }^{238} \mathrm{U}$ ages of $156 \pm 2 \mathrm{Ma}$ (spot KP11-621-24.1) and $161 \pm 2 \mathrm{Ma}$ (spot KP11-58816.2) were rejected due to high discordance in favour of their respective older

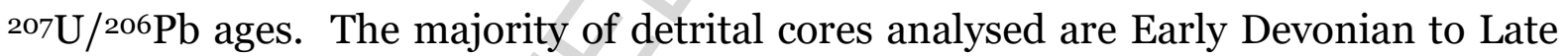
Triassic in age. The Proterozoic record is sporadic, with a few older grains that are Archean (the oldest analysis is KP11-619-16.2 with a $3416 \pm 8 \mathrm{Ma} 207 \mathrm{U} /{ }^{206} \mathrm{~Pb}$ age), which provides further confirmation that Seram formed part of the Australian continental margin.

The occurrence of Upper Triassic detrital zircon grains within the Kobipoto Complex migmatites reveals their protolith to be significantly younger than previously assumed. Audley-Charles et al. (1979) suggested that the Kobipoto Complex granulites of the Kobipoto Mountains were Precambrian in age, and subsequent studies identified the complex as 'Precambrian basement' to overlying Mesozoic (meta)sedimentary successions (Tjokrosapoetro and Budhitrisna, 1982; O’Sullivan et al., 1985; Kemp and Mogg, 1992; Pairault et al., 2003). Importantly, the Kobipoto Complex protolith is shown to be even younger than the Permian age commonly attributed to the associated Tehoru Formation and Taunusa Complex rocks (Valk, 1945; Germeraad, 1946; Tjokrosapoetro and Budhitrisna, 1982; 
Tjokrosapoetro et al., 1993a,b). Valk (1945) and Germeraad (1946) identified Triassic fossils in the overlying low-grade Saku Formation (their 'Greywacke and Glossy Slate Formation'), and we suggest these rocks must be of very similar age to the protoliths of the Tehoru Formation and Kobipoto Complex. In addition, Hall and Sevastjanova (2012) reported Late Triassic detrital U-Pb zircon ages for a Kanikeh Formation sandstone from the southern Kaibobo Peninsula (W Seram), which has been interpreted to stratigraphically overlie the Saku Formation (Tjokrosapoetro and Budhitrisna, 1982). Therefore, these new detrital age data suggest a Triassic protolith age for all metamorphic rocks on Seram (Kobipoto Complex, Tehoru Formation, and therefore Taunusa Complex), which may actually be partcontemporaneous with the over-thrust allochthonous successions of the Upper Triassic (Martini et al., 2004) Manusela Mountains Limestones.

The age distribution of detrital zircons on Seram is similar to those reported for the southern Banda Arc islands by Zimmermann and Hall (2016), suggesting a similar sediment provenance for sandstones of islands all around the Banda Embayment. This implies that sediments on Seram were therefore sourced both from the Bird's Head peninsula (West Papua) and from western Australia.

\section{Tectonic implications}

\subsection{What happened to Seram prior to the Mesozoic?}

Seram has been located in the NW Australian continental margin of Gondwana for as long as can be discerned. The record of detrital zircon ages presented here (Fig. 14) for the Kobipoto Complex of Seram and Ambon (see also Hall and Sevastjanova, 2010) dates back to the Archean, thus confirming the islands' affinities with the Australian continent (Pilbara and/or Yilgarn cratons) as opposed to Southeast Asia. The detrital age record (Fig. 14) shows most zircons are between 410 and $216 \mathrm{Ma}$, as is the case also for Timor, Babar, and Tanimbar (Zimmermann and Hall, 2016). No Silurian or Ordovician grains were dated, but there is a spread of ages from the Proterozoic in addition to a small number of Archean ages. Little more can currently be said about the pre-Triassic geological history of Seram. 


\subsection{What affected Seram in the Late Triassic-Early Jurassic?}

All three samples from the Kobipoto Mountains record Late Triassic-Early Jurassic ${ }^{206} \mathrm{U} /{ }^{238} \mathrm{~Pb}$ ages for the CL-bright (U-poor) $\mathrm{R}_{2}$ zones (Fig. 13). This spread of zircon ages, from $219 \pm 4 \mathrm{Ma}$ to $170 \pm 3 \mathrm{Ma}$, almost certainly records an important yet previously-unrecognised sequence of events. These $R_{2}$ zircon domains crystallised very soon after (a maximum of $1 \mathrm{Myr}$ ) the youngest detrital cores (Fig. 13), demonstrating a switch from a depositional to an orogenic environment at c. 215 Ma. Notably, a Late Triassic/Early Jurassic metamorphic/magmatic event is so far undocumented for Seram, and is completely unrecorded by $40 \mathrm{Ar} / 39 \mathrm{Ar}$ dating of the Tehoru Formation (Pownall et al., 2017).

In the Late Triassic (Fig. 16a), Seram belonged to the eastern Gondwanan margin, active then due to southwestward subduction of the Panthalassic (PaleoPacific) Ocean generating crustal melt and arc-related volcanism (Metcalfe, 1996, 2011; Hill and Hall, 2003). The Banda Embayment and Argo continental blocks had yet to rift from the NW Australian margin; thus the Proto-Banda sea had yet to form and the Sulu Spur was still connected to continental lithosphere to its south (Hall, 2012; see Fig. 16a). During this period, subduction under the Bird's Head peninsula, West Papua, produced 'Andean-type' arc-related granites and acid volcanic products from 248-213 Ma (Netoni Intrusive Complex; Webb and White, 2016), which during the Triassic shed sediments across the Bird's Head of New Guinea (the Tipuma Formation; Gunawan et al., 2014) and into the Banda region (Zimmermann and Hall, 2016). The detrital zircon record reported here for the Kobipoto Complex of Seram (Fig. 14) suggests it too received detrital input from the Bird's Head. An additional contribution may have also been made from the c. 217 Ma Banggai Granite Suite in the Banggai-Sula Islands (Sukamto, 1975).

By the Jurassic (Fig. 16b), subduction had ceased along the NW Australian margin, and rifting had begun to open the Eastern Ceno-Tethys (Wakita and Metcalfe, 2005; Hall, 2011). Hall (2012) reconstructed that rifting of the Banda Embayment Block from 160 Ma started to open the Proto-Banda Sea, based on the oldest documented magnetic anomalies in the Argo basin (Fullerton et al., 1989). Extension of the continental lithosphere around the Banda Embayment block must have started several Myr before the inception of oceanic spreading, and so an extensional environment preceding rifting is one potential candidate for having 
driven high- $T$, low- $P$ metamorphism and associated melting around the northern Banda Arc, as recorded by the $\mathrm{R}_{2}$ zircon (215-173 Ma). However, it is also likely that the Andean-type margin along the Sula Spur was still active until the end of the Triassic, and so metamorphism/magmatism associated with this subduction episode could account for the older $\mathrm{R}_{2}$ ages. The long duration ( $40 \mathrm{Myr}$ ) would permit multiple metamorphic-magmatic events to have taken place from 215 Ma up until rifting at c. $160 \mathrm{Ma}$, crystallising and perhaps reworking the $\mathrm{R}_{2}$ zircon.

The Tehoru and Kobipoto Complexes have since been over-thrust by Upper Triassic carbonate sequences of the Manusela Formation (or 'Asinipe Limestone'), which were deposited c. 230-201 Ma (Martini et al., 2004). Contrary to previous assumptions that the Tehoru and Kobipoto complexes were Permian or older (Valk, 1945; Audley-Charles et al., 1979; Tjokrosapoetro and Budhitrisna, 1982), Manusela Formation carbonates and the predominantly turbiditic protolith of the Tehoru Formation/Kobipoto Complex must have been deposited simultaneously between 230-216 Ma, prior to being juxtaposed by thrusting (the Manusela Formation is widely accepted as being allochthonous; Audley-Charles et al., 1979; Martini et al., 2004). The sharp and clear-cut change from detrital zircon ages $\left(C_{d}\right)$ to $R_{2}$ zircon crystallisation between 216 and $215 \mathrm{Ma}$ (Fig. 13) tightly brackets the transition from sedimentation to high-grade metamorphism and melting. These metamorphic and magmatic events were likely driven at first by subduction beneath the Sula Spur, and later by extension of the Sula Spur that led to the rifting of the Banda and Argo Blocks at c. $160 \mathrm{Ma}$ (that today comprise parts of Borneo and western Sulawesi; Hall, 2012; Hennig et al., 2016).

\subsection{Australia-SE Asia collision recorded on Seram?}

As shown in Figure 15, there are several zircon ages between 26 and 19 Ma. We suggest $\mathrm{U}-\mathrm{Pb}$ ages between $c$. 25.5 and 19.5 Ma obtained for $\mathrm{R}_{\mathrm{m}}$ zircon rims for samples KP11-588 and KP11-621 formed during a metamorphic event related to the collision of Australia (the Sula Spur) with SE Asia (the North Arm volcanic arc of Sulawesi), which has been reconstructed to have occurred from c. $23 \mathrm{Ma}$ (Hall, 2011, 2012). It is likely that crustal thickening resulting from the collision would have driven regional metamorphism ( \pm melting) at this time, such as that of the Tehoru Formation that recorded $40 \mathrm{Ar} / 39 \mathrm{Ar}$ ages of $17 \mathrm{Ma}$ linked to kyanite-grade 
metamorphism (Pownall et al., 2017). Middle Miocene ages have also been reported for central and northern Sulawesi (Advokaat et al., 2014; Hennig et al., 2016), which may also record the initial SE Asia-Australia collision.

\subsection{Timing of Tehoru Formation metamorphism and the nature of Seram's 'basement'}

The oldest ${ }^{40} \mathrm{Ar} /{ }^{39} \mathrm{Ar}$ age reported by Pownall et al. (2017) for the Tehoru Formation samples is 16.9 Ma. Therefore, no evidence was provided by that study for a metamorphic event on Seram predating the Miocene. However, here we show evidence for a metamorphic/magmatic event (or events) having occurred between 215-173 Ma, as recorded by $\mathrm{R}_{2}$ zircon zones from the Kobipoto Complex migmatites. In addition, the oldest possible protolith age is revealed here by the youngest detrital zircons to be Triassic (Section 6.5).

The $\mathrm{R}_{2}$ zircon must have grown in situ with the Kobipoto Complex during Triassic metamorphism. It is possible that the entire protolith to the Kobipoto Complex and Tehoru Formation (which was partially overprinted to form the Taunusa Complex) were deposited by $215 \mathrm{Ma}$, and that the complexes differ only in their styles of subsequent metamorphism, extent of melting, and degree of deformation. Alternatively, the Kobipoto Complex could have formed a metamorphic 'basement' on which the protolith to the Tehoru Formation were deposited slightly later during the Middle Jurassic and possibly into the Early Jurassic. In either scenario, it is entirely possible that the Tehoru Formation schists currently exposed on Seram may have been unmetamorphosed prior to c. 25-23 Ma, before the Sula Spur collided with Sulawesi. As alluded to before, this conclusion contradicts the interpretation made by previous authors (e.g. Audley-Charles et al., 1979, Tjokrosapoetro and Budhitrisna, 1982; Charlton, 2004; Hill, 2005) for a much older Permian metamorphic age for all Tehoru Formation rocks, based on the assumption that the Kobipoto Complex was either Palaeozoic or Precambrian (although the distinction between metamorphic age and protolith age was often not explicit). 
$\mathrm{U}-\mathrm{Pb}$ ages of Kobipoto Complex $\mathrm{R}_{\mathrm{m}}$ zircon, ${ }^{40} \mathrm{Ar} / 39 \mathrm{Ar}$ ages of biotite from Kobipoto Complex migmatites (Pownall et al., 2014), ${ }^{40} \mathrm{Ar} / 39 \mathrm{Ar}$ ages of white mica from Tehoru Formation schists (Pownall et al., 2017), and ${ }^{40} \mathrm{Ar} / 39 \mathrm{Ar}$ ages of phlogopite from lamprophyres intruding Kobipoto Complex lherzolites (Pownall et al., 2017) all record c. 16 Ma ages. We interpret these ages record a regional-scale metamorphic episode, driven by high- $T$ extensional exhumation of the SCLM, that generated UHT conditions in the Kobipoto Complex (Pownall et al., 2014; Pownall, 2015) and caused kyanite-grade regional metamorphism within the Tehoru Formation (Pownall et al., 2017).

The peridotite thermometry (Section 5.2 and Fig. 7) validates previous assertions that the Kobipoto Complex lherzolites could not have cooled far below typical shallow mantle ambient temperatures of $1280-1400^{\circ} \mathrm{C}$ (Herzberg et al., 2007) in order to have driven UHT metamorphism of the adjacent continental crust (Pownall, 2015) at $16 \mathrm{Ma}$. A $15.07 \pm 0.08 \mathrm{Ma}{ }^{40} \mathrm{Ar} / 39 \mathrm{Ar}$ age for phlogopite from a lamprophyric dyke intruded through the lherzolites and sourced from a mantle melt (Pownall et al., 2017), pinpoints the time when the shallow mantle cooled through the phlogopite closure temperature (Fig, 17a, 18) and provides further evidence for the cooling of the Kobipoto Complex from (ultra-)high-T conditions at c. 16 Ma.

\subsection{Kobipoto Complex exhumation on the Kaibobo Peninsula}

In western Seram (Kaibobo and Hoamoal peninsulas), Kobipoto Complex migmatites and ultramafic rocks are situated beneath low-angle detachment faults and sillimanite-grade shear zones (Pownall et al., 2013, 2017). 40 $\mathrm{Ar} / 39 \mathrm{Ar}$ dating of micas, which grew during high- $T$ shearing as the Kobipoto Complex was exhumed (Pownall et al., 2017), yielded ages of 5.88 \pm 0.05 Ma to $5.40 \pm 0.21$ Ma. These ages are identical within error to the $6.0 \pm 0.2 \mathrm{Ma}$ and $5.5 \pm 0.2 \mathrm{Ma} \mathrm{U}-\mathrm{Pb}$ zircon ages presented here for the adjacent diatexites, demonstrating common exhumation/shearing/cooling histories for rocks either side of the detachment.

In order for there to have been such high temperatures of metamorphism in the adjacent Taunusa Complex rocks $\left(\sim 740^{\circ} \mathrm{C}\right.$ at $\sim 5$ kbar; Linthout et al., 1989), Kobipoto Complex migmatites and lherzolites must have remained at elevated 
temperatures (perhaps $>800^{\circ} \mathrm{C}$ ) for $>10 \mathrm{Myr}$ after the UHT metamorphic peak, and $\mathrm{R}_{\mathrm{m}}$ garnet growth could not have occurred until the rocks underwent further retrogression during their exhumation beneath the extensional detachments at c. 5.5 Ma. The western Seram Kobipoto Complex migmatites must therefore have been held for $10.5 \mathrm{Myr}$ (from 16 to $5.5 \mathrm{Ma}$ ) at temperatures between $800-925^{\circ} \mathrm{C}$ and at $5^{-}$ $9 \mathrm{kbar}$. Temperatures must have been high enough to have heated adjacent rocks to $\sim 740^{\circ} \mathrm{C}$ (Linthout et al., 1989) but lower than peak UHT metamorphic temperatures ( $925^{\circ} \mathrm{C}$; Pownall, 2015); and pressures must have been between those experienced by peak Kobipoto Complex metamorphism (9 kbar; Pownall, 2015) and peak Taunusa Complex metamorphism (5 kbar; Linthout et al., 1989).

Many studies (e.g. Fraser et al., 1997; Roberts and Finger, 1997; Degeling et al., 2001; Harley et al., 2007; Sajeev et al., 2010; Kohn et al., 2015; Taylor et al., 2016) have demonstrated that zircon growth in high-grade metamorphic rocks occurs typically on the retrograde path when $\mathrm{Zr}$ is made available to form zircon by reactions that consume voluminous $\mathrm{Zr}$-incorporating minerals such as garnet. However, during cooling through the $P-T$ window inferred here for the western Seram migmatites, garnet is modelled to have increased steadily from 31 to $35 \mathrm{~mol} . \%$ abundance (Fig. 14a of Pownall, 2015), absorbing any free $\mathrm{Zr}^{4+}$ within the rock until 5.5 Ma. We propose that upon exhumation beneath detachment faults at c. 5.5 Ma, decompression of the migmatites through $7 \mathrm{kbar}$ would have driven the prevailing reaction garnet + sillimanite $\rightarrow$ cordierite + spinel (Pownall, 2015) which consumed garnet, liberated $\mathrm{Zr}$, and promoted $\mathrm{R}_{\mathrm{m}}$ zircon growth (Fig. 18).

The $\mathrm{R}_{\mathrm{m}}$ rims for samples SE10-178 and KB11-336 have a different appearance and different chemistry (e.g., higher $\mathrm{Th} / \mathrm{U}$ ratios) than the zircons from the Kobipoto Mountains samples (compare Fig. 11h and 11i). They are brighter in CL and have more pronounced zoning, similar to that expected for zircon of a magmatic origin. The rocks also contain a far higher proportion of leucosome, and the schlieren of residuum, although still ubiquitous to the rocks, are far smaller and scarcer. Both these features point to the Kaibobo Peninsula cordierite diatexites having undergone a greater degree of partial melting and melt migration, which makes sense given their stagnation between $800-900^{\circ} \mathrm{C}$ for $10.5 \mathrm{Myr}$. The presence of $c$. $200 \mathrm{Ma} \mathrm{R}_{2}$ zones in zircons from Kaibobo Peninsula sample SE10-178, the co-genetic relationship demonstrated in Figure 6, and similar field relations with respect to the 
ultramafic complex, all demonstrate an affinity between the diatexites in both Kaibobo and Kobipoto regions.

\subsection{Crustal melting and volcanism on Ambon}

Ages of the cordierite diatexites found on Ambon-the most voluminous of all-are 3.6-3.o Ma (J. Decker, pers. comm., 2010), as outlined in Table 1. They are younger still than those on the Kaibobo Peninsula, and exhibit a higher proportion of leucosome and a greater degree of mobilisation. The interpretations presented in Section 7.6 for the western Seram diatexites also apply to the Kobipoto Complex migmatites on Ambon; implying that that the Ambon rocks were exhumed at 3.5 Ma, after residing for 12.5 Myrs at temperatures between 800 and $900^{\circ} \mathrm{C}$, from depths greater than c. $20 \mathrm{~km}$. As they passed from this depth to pressures lower than $7 \mathrm{kbar}$, $R_{m}$ zircon crystallisation was triggered. The trace element profiles shown in Fig. 6 support these observations, demonstrating the Ambon cordierite diatexites are the most depleted of the Kobipoto Complex migmatites.

Cross-cutting relationships demonstrate that the leucogranites on Ambon are younger than the cordierite granites with which they are intimately associated, but as previously mentioned, the ${ }^{206} \mathrm{~Pb} /{ }^{238} \mathrm{U}$ ages of both lithologies are, within error, the same. Therefore, the leucogranites must be contemporaneous with the growth of $\mathrm{R}_{\mathrm{m}}$ zircon in Kobipoto Complex cordierite granites. We therefore interpret the leucogranites as the products of melting of the diatexites by the juxtaposed lherzolites that occurred during exhumation at 3.5 Ma, overprinting original (16 Ma) contact relations. All three units (lherzolite, leucogranite, and cordierite granite)

therefore share the same cooling history, with zircon in both the leucogranite and cordierite granite recording the same age.

Magmatic zircon rims from ambonite sample AB11-384 consistently record ${ }^{206} \mathrm{~Pb} /{ }^{238} \mathrm{U}$ ages of $1.9 \pm 0.2 \mathrm{Ma}$. This very young age can be related to emplacement of the dacite when the rock cooled rapidly from magmatic temperatures. This age is significantly younger than the previously-published groundmass K-Ar ages of $2.44 \pm$ 0.07 Ma (Honthaas, 1999), and whole-rock K-Ar ages of 4.35 Ma and 3.59-3.41 Ma (Abbott and Chamalaun, 1981), although a dacite boulder dredged from the seafloor 
south of Latimor gave an even younger whole-rock $\mathrm{K}-\mathrm{Ar}$ age of $0.75 \pm 0.06 \mathrm{Ma}$ (Silver et al., 1985).

This age is also significantly younger than a comparable SHRIMP U-Pb zircon age of $2.9 \pm 0.1 \mathrm{Ma}$ (J. Decker, pers. comm., 2010; Table 1) for an ambonite from SW Hitu (from the same outcrop as shown in Fig. 3a). Ambonite volcanism is therefore shown to have spanned at least a 1 Myr period, and episodic mobilisation of the Kobipoto Complex is demonstrated to have lasted from c. 16-2 Ma.

It should be emphasised that the trace element profiles shown in Fig. 6 strongly support previous proposals that the ambonites were derived almost entirely from the Kobipoto Complex migmatites. The ambonites thereby represent the ultimate product of SCLM-induced crustal melting in the 'cordierite province' of the northern Banda Arc.

\section{Conclusions}

The new $\mathrm{U}-\mathrm{Pb}$ ages and geochemical analyses, in the context of previous fieldbased studies on Seram and Ambon, support the following conclusions:

(1) Detrital zircon within Kobipoto Complex migmatites as old as $3.4 \mathrm{Ga}$ confirm that a component of their protolith was derived from the Archean cratons of western Australia. Strong similarities between the detrital zircon populations of Seram and the southern Banda Arc islands would suggest significant detrital input occurred from New Guinea during the Carboniferous, Triassic, and Jurassic.

(2) Late Triassic detrital zircon grains within the Kobipoto Complex migmatites demonstrate a maximum protolith age of $216 \mathrm{Ma}$ - this is significantly younger than previous assumptions of a Permian (or greater) age.

(3) A significant Late Triassic-Early Jurassic metamorphic/magmatic event is recorded by crystallisation of $215-173 \mathrm{Ma} \mathrm{R}_{2}$ zircon occurring in 4 of 5 Kobipoto Complex migmatite samples. This was most likely driven initially by subduction beneath the Sula Spur until the end of the Triassic, and then by lithospheric extension that culminated in the rifting of the Banda Embayment Blocks from the NW Australian margin (to open the Proto-Banda Sea) in the Late Jurassic. 
(4) The $\mathrm{R}_{2}$ zircon must have grown in situ with the Kobipoto Complex during Triassic metamorphism up until 215 Ma. Either the protolith to the overlying Tehoru Formation was also fully deposited by this time (and was either left unmetamorphosed or was metamorphosed at low grade during the Jurassic), or the Kobipoto Complex acted as a metamorphic 'basement' on which the protolith to the Tehoru Formation was later deposited during the Late Triassic to Early Jurassic.

(5) Australia-SE Asia collision between the Sula Spur and Sulawesi at c. 23 Ma is recorded by several c. 24-20 Ma zircon rim ages in the Kobipoto Complex migmatites. Tehoru Formation schists currently exposed on Seram may have been unmetamorphosed prior to this event (following either scenario outlined in point 4).

(6) c. $16 \mathrm{Ma}$ zircon rims $\left(\mathrm{R}_{\mathrm{m}}\right)$ occur in all 3 migmatites sampled from the Kobipoto Mountains. These samples each contain melanosomes preserving evidence of UHT ( $925^{\circ} \mathrm{C}$; $0.9 \mathrm{GPa}$ ) metamorphism, which overprinted the lower- $T \mathrm{R}_{2}$ event. We interpret these $16.5^{-15.5} \mathrm{Ma}{ }^{206} \mathrm{~Pb} /{ }^{238} \mathrm{U}$ zircon ages to date the post-peak near-isothermal decompression path from UHT conditions. At this stage, symplectic reaction microstructures would have formed at the expense of garnet and sillimanite, and $\mathrm{Zr}$ would have been made available to grow new zircon.

(7) Geothermometry of lherzolite from the Kobipoto Mountains indicates SCLM was juxtaposed against crustal rocks whilst at $1280-1300^{\circ} \mathrm{C}$, assuming lherzolites equilibrated slightly deeper than where adjacent granulites experienced peak metamorphism (0.9 GPa). The lherzolites were sufficiently hot to have driven UHT metamorphism and melting of the Kobipoto Complex migmatites.

(8) A $15.07 \pm 0.08 \mathrm{Ma}{ }^{40} \mathrm{Ar} / 39 \mathrm{Ar}$ age for phlogopite from a lamprophyric dyke intruded through the lherzolites (Pownall et al., 2017) records the cooling of the hot lherzolites in the Middle Miocene, at the time of UHT metamorphism. Under the inferred $P-T$ conditions, $\sim 10$ vol\% mantle melting would be expected, which is consistent with observations of scarce occurrences of harzburgite and gabbro.

(9) Co-genetic relationships between all members of the Kobipoto Complex migmatites, and the ambonites, are exhibited by N-MORB-normalised trace element patterns. This provides further evidence that cordierite diatexites in western Seram and on Ambon are part of the Kobipoto Complex migmatites which are best seen in the Kobipoto Mountains, and the UHT granulites 
comprise the residual component. Furthermore, the ambonites were derived almost entirely from melting of the Kobipoto Complex migmatites.

(10) Cordierite diatexites on the Kaibobo Peninsula, W Seram, record 6.0-5.5 Ma $\mathrm{U}-\mathrm{Pb} \mathrm{R}_{\mathrm{m}}$ zircon ages. These rocks were exhumed, still at high temperature, beneath on low-angle detachment faults, and their $\mathrm{U}-\mathrm{Pb}$ zircon ages are within error of ${ }^{40} \mathrm{Ar} / 39 \mathrm{Ar}$ ages of micas from sillimanite-grade Taunusa Complex shear zones comprising the hanging wall (Linthout et al., 1996; Pownall et al., 2017).

(11) The Tehoru Formation and Taunusa Complex originated from a common Late Triassic (to Jurassic) sedimentary protolith and differ only in their styles of metamorphism, extent of melting, and degree of deformation (as controlled by their proximity to the exhumed Kobipoto Complex rocks).

(12)Whereas the granulites in the Kobipoto Mountains were exhumed and cooled at $16 \mathrm{Ma}$, shortly after the peak of UHT metamorphism, Kobipoto Complex rocks in western Seram (and Ambon) must have remained for a further 10.5 Myr (or, for Ambon, 12.5 Myr) at about 9 kbar depth (Pownall, 2015)-where they cooled slowly, but remained at temperatures $>800^{\circ} \mathrm{C}$ (and therefore in the garnet stability field; Pownall, 2015)-before they were exhumed beneath the detachment faults at $6 \mathrm{Ma}$.

(13)Leucogranites generated between Kobipoto Complex migmatites and lherzolites on Ambon record similar 3.5 Ma U-Pb zircon ages to the diatexites they intruded, which we interpret to have occurred during localised exhumation, when $R_{m}$ zircon within the diatexites grew in response to decompression.

(14)Ambonite volcanism on Ambon from c. 3.0-1.9 Ma was the product predominantly of melting of the Kobipoto Complex migmatites. The ambonites are therefore quite different from the arc volcanic products erupted between Banda Island and Romang.

These findings demonstrate how substantial lithospheric extension driven by slab rollback can drive short-lived pulses of UHT metamorphism and melting of the continental crust.

\section{Acknowledgements}


We are extremely grateful to Yasinto Priastomo and Ramadhan Adhitama (Institut Teknologi Bandung) for assistance in the field. Matthew Thirlwall and Christina Manning are thanked for their assistance in acquiring the whole-rock XRF data, and Andy Beard is thanked for assistance with EMP analysis. The paper benefited greatly from reviews by Brad Hacker and Hans Vrijmoed, and from the editorship of Taras Gerya. This research was funded by the SE Asia Research Group (Royal Holloway University of London) and Australian Research Council (ARC) grant DE160100128 awarded to JMP.

\section{REFERENCES}

Abbott, M.J., Chamalaun, F.H., 1981. Geochronology of some Banda Arc volcanics, in: Barber, A.J., Wiryusujono, S. (Eds.), The Geology and Tectonics of Eastern Indonesia. Geological Research and Development Centre, Special Publication, Bandung, pp. 253-268.

Advokaat, E.L., Hall, R., White, L.T., Armstrong, R., Kohn, B., BouDagher-Fadel, M.K., 2014. Neogene extension and exhumation in NW Sulawesi. AGU Fall Meeting 2014, T43A-4701.

Audley-Charles, M.G., Carter, D.J., Barber, A.J., Norvick, M.S., Tjokrosapoetro, S., 1979. Reinterpretation of the geology of Seram: implications for the Banda Arcs and northern Australia. Journal of the Geological Society 136, 547-566.

Black, L.P., Kamo, S.L., Allen, C.M., Davis, D.W., Aleinikoff, J.N., Valley, J.W., Mundil, R., Campbell, I.H., Korsch, R.J., Williams, I.S., Foudoulis, C., 2004. Improved Pb-206/U-218 microprobe geochronology by the monitoring of a trace-element-related matrix effect; SHRIMP, ID-TIMS, ELA-ICP-MS and oxygen isotope documentation for a series of zircon standards. Chemical Geology 205, 115-140.

Bowin, C., Purdy, G.M., Johnston, C., Shor, G., Lawyer, L., Hartono, H., Jezek, P., 1980. Arc-continent collision in the Banda Sea region. AAPG Bulletin 64, 868915 . 
Brey, G.P., Köhler, T., 1990. Geothermobarometry in four-phase lherzolites II. New thermometers, and practical assessment of existing thermobarometers. Journal of Petrology 31, 1353-1378.

Brouwer, H.A., 1925. Over insluitsels en cordierietgehalte van bronzietdacieten van het eiland Amboina. Verhand. Geol. Mijnb. Gen. Nederland. Kol., Geol. Ser. 8, 73-80.

Charlton, T.R., 2004. The petroleum potential of inversion anticlines in the Banda Arc. AAPG Bulletin 88, 565-585. doi:10.1306/12290303055

Corfu, F., Hanchar, J.M., Hoskin, P.W.O., Kinny, P., 2003. Atlas of Zircon Textures, in: Hanchar, J.M., Hoskin, P.W.O. (Eds.), Reviews in Mineralogy and Geochemistry: Volume 53: Zircon. Mineralogical Society of America, Washington, District of Columbia.

Defant, M.J., Drummond, M.S., 1990. Subducted lithosphere-derived andesitic and dacitic rocks in young volcanic arc setting. Nature 347, 662-665. doi:10.1029/GMo76poo39/summary

Degeling, H., Eggins, S., Ellis, D.J., 2001. Zr budgets for metamorphic reactions, and the formation of zircon from garnet breakdown. Mineralogical Magazine 65, 749-758.

de Jong, H., 1923. Studien uber Eruptiv- und Mischgesteine des Kaibobogebietes. Geol. Petrogr. and Pal. Results of Explorations in the Isle of Ceram 1.

Ely, K.S., Sandiford, M., Phillips, D., Boger, S.D., 2014. Detrital zircon U-Pb and 40Ar/39Ar hornblende ages from the Aileu Complex, Timor-Leste: provenance and metamorphic cooling history. Journal of the Geological Society 171, 299309. doi:10.1144/jgs2012-065

Fraser, G., Ellis, D., Eggins, S., 1997. Zirconium abundance in granulite-facies minerals, with implications for zircon geochronology in high-grade rocks. Geology 25, 607-610. doi:10.1130/00917613(1997)025<0607:ZAIGFM>2.3.CO;2

Fullerton, L.G., Sager, W.W., Handschumacher, D.W., 1989. Late Jurassic-Early Cretaceous evolution of the eastern Indian Ocean adjacent to northwest Australia. Journal of Geophysical Research: Solid Earth (1978-2012) 94, 29372953. doi:10.1029/JBo94iBo3p02937

Germeraad, J.H., 1946. Geology of central Seran, in: Rutten, L., Hotz, W. (Eds.), Geological, Petrographical, and Palaeontological Results of Explorations, 
Carried Out From September 1917 Till June 1919 in the Island of Ceram. De Bussy, Amsterdam, p. 135.

Gunawan, I., Hall, R., Sevastjanova, I., 2012. Age, Character and Provenance of the Tipuma Formation, West Papua: New Insights from Detrital Zircon Dating. Indonesian Petroleum Association, Proceedings of the $36^{\text {th }}$ Annual Convention, IPA12-G-027.

Gunawan, I., Hall, R., Augustsson, C., Armstrong, R., 2014. Quartz from the Tipuma Formation, West Papua: New insights from geochronology and cathodoluminescence studies. Indonesian Petroleum Association, Proceedings of the $38^{\text {th }}$ Annual Convention, IPA14-G-303.

Hall, R., 2002. Cenozoic geological and plate tectonic evolution of SE Asia and the SW Pacific: computer-based reconstructions, model and animations. Journal of Asian Earth Sciences 20, 353-431. doi:10.1016/S1367-9120(01)ooo69-4

Hall, R., 2011. Australia-SE Asia collision: plate tectonics and crustal flow, in: Hall, R., Cottam, M.A., Wilson, M.E.J. (Eds.), The SE Asian Gateway: History and Tectonics of the Australia-Asia Collision. Geological Society, London, Special Publications 355, 75-109. doi:10.1144/SP355.5

Hall, R., 2012. Late Jurassic-Cenozoic reconstructions of the Indonesian region and the Indian Ocean. Tectonophysics 570-571, 1-41. doi:10.1016/j.tecto.2012.04.021

Hall, R., 2014. Indonesian tectonics: Subduction, extension, provenance and more. Indonesian Petroleum Association, Proceedings of the 38 th Annual Convention, IPA14-G-360.

Hall, R., Wilson, M.E.J., 2000. Neogene sutures in eastern Indonesia. Journal of Asian Earth Sciences 18, 781-808.

Hall, R., Sevastjanova, I., 2012. Australian crust in Indonesia. Australian Journal of Earth Sciences 59, 827-844. doi:10.1080/08120099.2012.692335

Hall, R., Spakman, W., 2002. Subducted slabs beneath the eastern Indonesia-Tonga region: insights from tomography. Earth and Planetary Science Letters 201, 321-336. doi:10.1016/So012-821X(02)00705-7

Hall, R., Spakman, W., 2015. Mantle structure and tectonic history of SE Asia. Tectonophysics 658, 14-45. doi:10.1016/j.tecto.2015.07.003

Hall, R., Patria, A., Adhitama, R., Pownall, J.M., White, L.T., 2017. Seram, the Seram Trough, the Aru Trough, the Tanimbar Trough and the Weber Deep: A new look 
at major structures in the eastern Banda Arc. Indonesian Petroleum Association, Proceedings of the 41st Annual Convention, IPA17-91-G.

Hamilton, W., 1979. Tectonics of the Indonesian region. US Geological Survey Professional Paper 1078, 345 pp.

Harley, S.L., Kelly, N.M., Möller, A., 2007. Zircon behaviour and the thermal histories of mountain chains. Elements 3, 25-30.

Harrell, F.E., 2013. Package "Hmisc." R package. http://CRAN.Rproject.org/package $=$ Hmisc

Harris, R., 2006. Rise and fall of the Eastern Great Indonesian arc recorded by the assembly, dispersion and accretion of the Banda Terrane, Timor. Gondwana Research 10, 207-231. doi:10.1016/j.gr.2006.05.010

Harris, R., 2011. The nature of the Banda arc-continent collision in the Timor region, in: Brown, D., Ryan, P.D. (Eds.), Arc-Continent Collision, Frontiers in Earth Sciences. Springer Berlin Heidelberg, Berlin, Heidelberg, pp. 163-211. doi:10.1007/978-3-540-88558-0_7

Helmers, H., Sopaheluwakan, J., Tjokrosapoetro, S., Nila, E., 1989. High-grade metamorphism related to peridotite emplacement near Atapupu, Timor with reference to the Kaibobo peridotite on Seram, Indonesia. Netherlands Journal of Sea Research 24, 357-371. doi:10.1016/o077-7579(89)90161-o

Hennig, J., Advokaat, E., Rudyawan, A., Hall, R., 2014. Large sediment accumulations and major subsidence offshore; rapid uplift on land: consequences of extension of Gorontalo Bay and Northern Sulawesi. Indonesian Petroleum Association, Proceedings of the 38th Annual Convention, IPA14-G-304.

Hennig, J., Hall, R., Armstrong, R.A., 2016. U-Pb zircon geochronology of rocks from west Central Sulawesi, Indonesia: Extension-related metamorphism and magmatism during the early stages of mountain building. Gondwana Research 32, 41-63. doi:10.1016/j.gr.2014.12.012.

Herzberg, C., Zhang, J, 1996. Melting experiments on anhydrous peridotites KLB-1: Compositions of magmas in the upper mantle and transition zone. Journal of Geophysical Research 101, 8271-8295.

Herzberg, C., Asimow, P.D., Arndt., N., Niu, Y., Lesher, C.M., Fitton, J.G., Cheadle, M.J., Saunders, A.D., 2007. Temperatures in ambient mantle and plumes: 
Constraints from basalts, picrites, and komatiites. Geochemistry, Geophysics, Geosystems 8, Q02006, doi:10.1029/2006GCo01390.

Hill, K.C., 2005. Tectonics and Regional Structure of Seram and the Banda Arc.

Indonesian Petroleum Association, Proceedings of the 3oth Annual Convention, 559-578.

Hill, K.C., Hall, R., 2003. Mesozoic-Tertiary evolution of Australia's New Guinea Margin in a west Pacific context, in: Hillis, R., Müller, R.D. (Eds.), The Evolution and Dynamics of the Australian Plate. Geological Society of Australia Special Publication, 22, 265-289.

Hinschberger, F., Malod, J.A., Réhault, J.-P., Villeneuve, M., Royer, J.-Y., Burhanuddin, S., 2005. Late Cenozoic geodynamic evolution of eastern Indonesia. Tectonophysics 404, 91-118. doi:10.1016/j.tecto.2005.05.005

Holland, T.J.B., 2016. AX: A program to calculate activities of mineral end-members from chemical analyses. Available at:

http://www.esc.cam.ac.uk/research/research-groups/holland/ax (last accessed on 7 June 2016).

Honthaas, C., Maury, R.C., Priadi, B., Bellon, H., Cotten, J., 1999. The PlioQuaternary Ambon arc, Eastern Indonesia. Tectonophysics 301, 261-281. doi:10.1016/So040-1951(98)00227-3

Hutchison, C.S., 1976. Discussion of Carter, D. J. et al., 1976, in: Proceedings: Society Meetings September - December 1975. Journal of the Geological Society, London, pp. 358-361.

Jezek, P.A., Hutchison, C.S., 1978. Banda arc of eastern Indonesia: Petrology and geochemistry of the volcanic rocks. Bulletin of Volcanology 41, 586-608. doi:10.1007/BF02597389

Jongsma, D., Woodside, J., Huson, W., Suparka, S., Kadarisman, D., 1989. Geophysics and tentative late Cenozoic seismic stratigraphy of the Banda ArcAustralian continent collision zone along three transects. Netherlands Journal of Sea Research 24, 205-229. doi:10.1016/o077-7579(89)90150-6

Kadarusman, A., Maruyama, S., Kaneko, Y., Ota, T., Ishikawa, A., Sopaheluwakan, J., Omori, S., 2010. World's youngest blueschist belt from Leti Island in the nonvolcanic Banda outer arc of Eastern Indonesia. Gondwana Research 18, 189204. doi:10.1016/j.gr.2010.02.009 
Kemp, G., Mogg, W., 1992. A reappraisal of the geology, tectonics and prospectivity of Seram Island, Eastern Indonesia. Indonesian Petroleum Association, Proceedings of the 21th Annual Convention , 521-552.

Kohn, M.J., Corrie, S.L., Markley, C., 2015. The fall and rise of metamorphic zircon. American Mineralogist 100, 897-908.

Kretz, R., 1983. Symbols for rock-forming minerals. American Mineralogist 68, 277279.

Kuenen, P.H., 1949. Ambon and Haroekoe. Koninkl. Netherlands Geol. Mijnbouw. Genoot. Verh. Geol. Ser. 15, 44-62.

Lemon, J., Bolker, B., Oom, S., et al., 2013. Package “plotrix.”. R package. http://CRAN.R-project.org/package=plotrix

Linthout, K., Helmers, H., 1994. Pliocene obducted, rotated and migrated ultramafic rocks and obduction-induced anatectic granite, SW Seram and Ambon, Eastern Indonesia. Journal of Southeast Asian Earth Sciences 9, 95-109. doi:10.1016/0743-9547(94)90068-X

Linthout, K., Helmers, H., Sopaheluwakan, J., Nila, E.S., 1989. Metamorphic complexes in Buru and Seram, Northern Banda Arc. Netherlands Journal of Sea Research 24, 345-356. doi:10.1016/0077-7579(89)90160-9

Linthout, K., Helmers, H., Andriessen, P., 1991. Dextral strike-slip in Central Seram and 3-4.5 $\mathrm{Ma} \mathrm{Rb} / \mathrm{Sr}$ ages in pre-Triassic metamorphics related to early Pliocene counterclockwise rotation of the Buru-Seram microplate (E. Indonesia). Journal of Southeast Asian Earth Sciences 6, 335-342. doi:10.1016/07439547(91)90079-D

Linthout, K., Helmers, H., Wijbrans, J.R., Van Wees, J.D.A.M., 1996. 40Ar/39Ar constraints on obduction of the Seram ultramafic complex: consequences for the evolution of the southern Banda Sea. Geological Society, London, Special Publications 106, 455-464. doi:10.1144/GSL.SP.1996.106.01.28

Linthout, K., Helmers, H., Sopaheluwakan, J., 1997. Late Miocene obduction and microplate migration around the southern Banda Sea and the closure of the Indonesian Seaway. Tectonophysics 281, 17-30. doi:10.1016/So0401951(97)00156-X

Ludwig, K.R., 2003. Isoplot 3.0: A geochronological toolkit for Microsoft Excel. Berkeley Geochronological Centre Special Publication 4. 
Ludwig, K.R., 2009. SQUID 2: A user's manual. Berkeley Geochronological Centre Special Publication 5 .

Magaritz, M., Whitford, D.J., James, D.E., 1978. Oxygen isotopes and the origin of high ${ }^{87} \mathrm{Sr} /{ }^{86} \mathrm{Sr}$ andesites. Earth and Planetary Science Letters 40, 220-230.

Manatschal, G., Lavier, L., and Chenin, P., 2015. The role of inheritance in structuring hyperextended rift systems: Some considerations based on observations and numerical modelling. Gondwana Research 27, 140-164.

Martin, K., 1901. Over de geologie van West-Seran (Ceram). Handeling 8e Geneeskunde, Nederlands Natuur en Geneeskundig Congres, Rotterdam 301303.

Martini, R., Zaninetti, L., Lathuillière, B., Cirilli, S., Cornée, J.-J., Villeneuve, M., 2004. Upper Triassic carbonate deposits of Seram (Indonesia):

palaeogeographic and geodynamic implications. Palaeogeography,

Palaeoclimatology, Palaeoecology 206, 75-102.

doi:10.1016/j.palaeo.2003.12.020

Metcalfe, I., 1996. Pre-Cretaceous evolution of SE Asian terranes, in: Hall, R., Blundell, D. (Eds.), Tectonic Evolution of Southeast Asia. The Geological Society, Special Publication, London, pp. 97-122.

Metcalfe, I., 2011. Palaeozoic-Mesozoic history of SE Asia, in: Hall, R., Cottam, M.A., Wilson, M.E.J. (Eds.), The SE Asian Gateway: History and Tectonics of the Australia-Asia Collision. The Geological Society, Special Publication, London, pp. 7-35.

Milsom, J., 1977. Preliminary gravity map of Seram, eastern Indonesia. Geology 5, 641-643.

Milsom, J., 2001. Subduction in eastern Indonesia: how many slabs? Tectonophysics 338, 167-178. doi:10.1016/So040-1951(01)00137-8

Milsom, J., Sardjono, Susilo, A., 2001. Short-wavelength, high-amplitude gravity anomalies around the Banda Sea, and the collapse of the Sulawesi orogen. Tectonophysics 333, 61-74. doi:10.1016/So040-1951(00)00267-5

Monnier, C., Girardeau, J., Permana, H., Rehault, J.P., Bellon, H., Cotten, J., 2003. Dynamics and age of formation of the Seram-Ambon ophiolites (Central Indonesia). Bulletin de la Société Géologique de France 174, 529-543. doi:10.2113/174.6.529 
Nimis, P., Taylor, W.R., 2000. Single-clinopyroxene thermobarometry for garnet peridotites. Part I. Calibration and testing of a Cr-in-Cpx barometer and an enstatite-in-Cpx thermometer. Contributions to Mineralogy and Petrology 139, 541-554.

Nimis, P., Grütter, H., 2010. Internally consistent geothermometers for garnet peridotites and pyroxenites. Contributions to Mineralogy and Petrology 159, 411-427. doi:10.1007/so0410-009-0455-9

O’Sullivan, T., Pegum D., Tarigan J., 1985. Seram oil search: past discoveries and future potential. Indonesian Petroleum Association, Proceedings of the 14th Annual Convention, 3-20.

Ota, T., Kaneko, Y., 2010. Blueschists, eclogites, and subduction zone tectonics: Insights from a review of Late Miocene blueschists and eclogites, and related young high-pressure metamorphic rocks. Gondwana Research 18, 167-188. doi:10.1016/j.gr.2010.02.013

Pairault, A.A., Hall, R., Elders, C.F., 2003. Structural styles and tectonic evolution of the Seram Trough, Indonesia. Marine and Petroleum Geology 20, 1141-1160. doi:10.1016/j.marpetgeo.2003.10.001

Pownall, J.M., 2015. UHT metamorphism on Seram, eastern Indonesia: reaction microstructures and $\mathrm{P}-\mathrm{T}$ evolution of spinel-bearing garnet-sillimanite granulites from the Kobipoto Complex. Journal of Metamorphic Geology 33, 909-935. doi:10.1111/jmg.12153

Pownall, J.M., Hall, R., 2014. Neogene extension on Seram: A new tectonic model for the northern Banda Arc. Indonesian Petroleum Association, Proceedings of the $38^{\text {th }}$ Annual Convention, IPA14-G-305.

Pownall, J.M., Hall, R., Watkinson, I.M., 2013. Extreme extension across Seram and Ambon, eastern Indonesia: evidence for Banda slab rollback. Solid Earth 4, 277-314. doi:10.5194/se-4-277-2013

Pownall, J.M., Hall, R., Armstrong, R.A., Forster, M.A., 2014. Earth’s youngest known ultrahigh-temperature granulites discovered on Seram, eastern Indonesia. Geology 42, 279-282. doi:10.1130/G35230.1

Pownall, J.M., Hall, R., Lister, G.S., 2016. Rolling open Earth's deepest forearc basin. Geology 44, 947-950. doi:10.1130/G38051.1.

Pownall, J.M., Forster, M.A., Hall, R., Watkinson, I.M, 2017. Tectonometamorphic evolution of Seram and Ambon, eastern Indonesia: Insights from 40 $\mathrm{Ar} / 39 \mathrm{Ar}$ 
geochronology. Gondwana Research 44, 35-53. doi:10.1016/j.gr.2016.10.018 Priem, H.N.A., Andriessen, P.A.M., Boelrijk, N.A.I.M., Hebeda, E.H., Hutchinson, C.S., Verdurmen, E.A.T., Versschure, R.H., 1978. Isotopic evidence for a middle to late Pliocene age of the cordierite granite on Ambon, Indonesia. Geologie en Mijnbouw 57, 441-443.

R Core Team, 2013. R: A language and environment for statistical computing. $\mathrm{R}$ Foundation for Statistical Computing. Vienna, Austria, http://www.Rproject.org/.

Richards, S., Lister, G., Kennett, B., 2007. A slab in depth: Three-dimensional geometry and evolution of the Indo-Australian plate. Geochemistry, Geophysics, Geosystems 8. doi:10.1029/2007GCo01657

Rittmann, A., 1931. Gesteine von Kellang und Manpia, in: Rutten, L.M.R., Hotz, W. (Eds.), Geological, Petrographical, and Palaeontological Results of Explorations, Carried Out From September 1917 Till June 1919 in the Island of Ceram. De Bussy, Amsterdam.

Roberts, M.P., Finger, F., 1997. Do U-Pb zircon ages from granulites reflect peak metamorphic conditions? Geology 25, 319-322. doi:10.1130/oo917613(1997)025<0319:DUPZAF>2.3.CO;2

Sajeev, K., Williams, I.S., Osanai, Y., 2010. Sensitive high-resolution ion microprobe $\mathrm{U}-\mathrm{Pb}$ dating of prograde and retrograde ultrahigh-temperature metamorphism as exemplified by Sri Lankan granulites. Geology 38, 971-974.

Sawyer, E.W., 2008. Atlas of Migmatites, 9 ed. The Canadian Mineralogist, Special Publication, Ottawa, Canada.

Schroeder van der Kolk, J.L.C., 1902. Mikroskopische Studien ueber Gesteine aus den Molukken, pt. 2 - Gesteine von Seran. Geol. Reichs-Museums Leiden, Samml. 6, 1-39.

Silver, E.A., Gill, J.B., Schwartz, D., Prasetyo, H., Duncan, R.A., 1985. Evidence for a submerged and displaced continental borderland, north Banda Sea, Indonesia. Geology 13.

Sopaheluwakan, J., Linthout, K., Helmers, H., Permana, H., 1992. Peridotitemetamorphite relation in West Seram: constraints to the vertical movements of the North Banda Arc. Proceedings of the Indonesian Association of Geologists 21, 599-609. 
Spakman, W., Hall, R., 2010. Surface deformation and slab-mantle interaction during Banda arc subduction rollback. Nature Geoscience 3, 562-566. doi:10.1038/ngeo917

Steiger, R.H., Jäger, E., 1977. Subcommission on geochronology: Convention on the use of decay constants in geo- and cosmoschronology. Earth and Planetary Science Letters 36, 359-362.

Sukamto, R., 1975. Geological Map of Indonesia, Ujung Pandang Sheet. Scale 1:1 000 ooo. Geological Survey of Indonesia, Directorate of Mineral Resources, Geological Research and Development Centre, Bandung, Indonesia.

Sun, S.S., McDonough, W.F., 1989. Chemical and isotopic systematics of oceanic basalts: implications for mantle composition and processes, in: Saunders, A.D., Norry, M.J. (Eds.), Magmatism in the Ocean Basins. The Geological Society, Special Publication, 313-345.

Takahashi, E., 1986, Melting of a dry peridotites KLB-1 up to 14 GPa: Implications on the origin of peridotitic upper mantle. Journal of Geophysical Research 91, 9367-9382.

Takahashi, E., Shimazaki, T., Tsuzaki, Y., Yoshida, H., 1993. Melting study of a peridotites KLB-1 to 6.5 GPa, and the origin of basaltic magmas. Philosophical Transactions of the Royal Society A: Mathematical, Physical and Engineering Sciences 342, 105-120. doi:10.1098/rsta.1993.0008

Taylor, W.R., 1998. An experimental test of some geothermometer and geobarometer formulations for upper mantle peridotites with application to thermobarometry of fertile lherzolite and garnet websterite. Neues Jahrbuch für mineralogy, Abhandlungen 172, 381-408.

Taylor, R.J.M, Kirkland, C.L., Clark C., 2016. Accessories after the facts: Constraining the timing, duration and conditions of high-temperature metamorphic processes. Lithos 264, 239-257. doi:10.1016/j.lithos.2016.09.004

Thompson, R.N., Gibson, S.A., 2000. Transient high temperatures in mantle plume heads inferred from magnesian olivines in Phanerozoic picrites. Nature 407, 502-506.

Tjokrosapoetro, S., Budhitrisna, T., 1982. Geology and tectonics of the northern Banda Arc. Bulletin of the Indonesian Geological Research and Development Centre 6, 1-17. 
Tjokrosapoetro, S., Achdan, A., Suwitodirdjo, K., Rusmana, E., Abidin, H.Z., 1993a. Geological map of the Masohi quadrangle, Maluku, 1:250,ooo. Geological Research and Development Centre, Bandung, Indonesia.

Tjokrosapoetro, S., Budhitrisna, T., Rusmana, E., 1993b. Geology of the Buru

Quadrangle, Maluku, 1:250,ooo. Geological Research and Development Centre, Bandung.

Valk, W., 1945. Contributions to the geology of West Seran, in: Rutten, L., Hotz, W. (Eds.), Geological, Petrographical, and Palaeontological Results of Explorations, Carried Out From September 1917 Till June 1919 in the Island of Ceram. De Bussy, Amsterdam, p. 104.

van Bemmelen, R.W., 1949. The geology of Indonesia. Government Printing Office, Matinus Nijhoff, The Hague.

van Bergen, M.J., Erfan, R.D., Sriwana, T., Suharyono, K., Poorter, R.P.E., Varekamp, J.C., Vroon, P.Z., Wlrakusumah, A.D., 1989. Spatial geochemical variations of arc volcanism around the Banda Sea. Netherlands Journal of Sea Research 24, 313-322.

van Leeuwen, T., Allen, C.M., Elburg, M., Massonne, H.-J., Palin, J.M., Hennig, J., 2016. The Palu Metamorphic Complex, NW Sulawesi, Indonesia: Origin and evolution of a young metamorphic terrane with links to Gondwana and Sundaland. Journal of Asian Earth Sciences 115, 133-152. doi:10.1016/j.jseaes.2015.09.025

Verbeek, R.D.M., 1905. Geologische beschrijving van Ambon. Jaarboek van het mijnwezen in Nederlandsch Oost-Indië 29, 308.

Villeneuve, M., Martini, R., Bellon, H., Réhault, J.-P., Cornee, J.-J., Bellier, O., Burhannuddin, S., et al., 2010. Deciphering of six blocks of Gondwanan origin within Eastern Indonesia (South East Asia). Gondwana Research 18, 420-437. doi:10.1016/j.gr.2009.12.011

Vroon, P.Z., Lowry, D., van Bergen, M.J., Boyce, A.J., Mattey, D.P., 2001. Oxygen isotope systematics of the Banda Arc: low $\delta^{18} \mathrm{O}$ despite involvement of subducted continental material in magma genesis. Geochimica et Cosmochimica Acta 65, 589-609. doi:10.1016/So016-7037(00)o0554-8

Vroon, P.Z., van Bergen, M.J., White, W.M., Varekamp, J.C., 1993. Sr-Nd-Pb isotope systematics of the Banda Arc, Indonesia: combined subduction and 
assimilation of continental material. J. Geophys. Res. 98, 22349-22366. doi:10.1029/93JBo1716

Wakita, K., Metcalfe, I., 2005. Ocean plate stratigraphy in East and Southeast Asia. Journal of Asian Earth Sciences 24, 679-702.

Watkinson, I.M., 2011. Ductile flow in the metamorphic rocks of central Sulawesi, in: Hall, R., Cottam, M.A., Wilson, M.E.J. (Eds.), The SE Asian Gateway: History and Tectonics of the Australia-Asia Collision. Geological Society, London, Special Publications 355, 157-176. doi:10.1144/SP355.8

Watkinson, I.M, and Hall, R., 2016. Active faults of Eastern Indonesia, in: Cummins, P., Meilano, I. (Eds.), Geohazards in Indonesia: Earth Science for Disaster Risk Reduction. Geological Society, London, Special Publications 441, doi:10.1144/SP441.8

Webb, M., White, L.T., 2016. Age and nature of Triassic magmatism in the Netoni Intrusive Complex, West Papua, Indonesia. Journal of Asian Earth Sciences 132, 58-74. doi:10.1016/jseaes.2016.09.019

White, L.T., Hall, R., Armstrong, R.A., 2014. The age of undeformed dacite intrusions within the Kolaka Fault zone, SE Sulawesi, Indonesia. Journal of Asian Earth Sciences 94, 105-112. doi:10.1016/j.jseaes.2014.08.014

Whitford, D.J., Compston, W., Nicholls, I.A., Abbott, M.J., 1977. Geochemistry of late Cenozoic lavas from eastern Indonesia: role of subducted sediments in petrogenesis. Geology 5, 571-575.

Whitford, D.J., Jezek, P.A., 1979. Origin of late Cenozoic lavas from the Banda Arc, Indonesia: trace elements and Sr isotope evidence. Contributions to Mineralogy and Petrology 68, 141-150.

Whitford, D.J., Jezek, P.A., 1982. Isotopic constraints on the role of subducted sialic material in Indonesian island-arc magmatism. Geol Soc America Bull 93, 504513 .

Williams, I.S., 1998. U-Th-Pb geochronology by ion microprobe, in: McKibben, M.A., Shanks III, W.C., Ridley, W.I. (Eds.), Applications of Microanalytical Techniques to Understanding Mineralizing Processes. Reviews in Economic Geology, v. 7, pp. 1-35.

Zeck, H.P., 1970. An erupted migmatite from Cerro del Hoyazo, SE Spain. Contrib Mineral Petrol 26, 225-246. 
Zeck, H.P., Williams, I.S., 2002. Inherited and magmatic zircon from Neogene Hoyazo cordierite dacite, SE Spain - Anatectic source rock provenance and magmatic evolution. Journal of Petrology 43, 1089-1104.

Zimmermann, S., Hall, R., 2016. Provenance of Triassic and Jurassic sandstones in the Banda Arc: Petrography, heavy minerals and zircon geochronology. Gondwana Research 37, 1-19. doi:10.1016/j.gr.2016.06.001

\section{FIGURES}

Fig. 1 (a) Tectonic map of Eastern Indonesia and the surrounding region showing the location of Seram and Ambon, located in the northern limb of the Banda Arc. Subduction zones and major faults are modified from Hall (2012). The newly recognized Banda Detachment follows Pownall et al. (2016). The digital elevation model combines ASTER topography (asterweb.jpl.nasa.gov) and GEBCO bathymetry (gebco.net). (b) Geological map of Seram and Ambon (after Pownall et al., 2013), located in part 'a' by the black box, showing sample locations.

Fig. 2 Field photos of the Kobipoto Complex on Seram and Ambon. (a) Detachment fault on the Kaibobo Peninsula, western Seram, juxtaposing peridotites against deformed Taunusa Complex gneisses that comprise the hanging wall. (b) Large boulders of cordierite diatexite (sampling location of SE10-178) in a river leading into Teluk Tihimolon from Gunung Hemahuhui, Kaibobo Peninsula, W Seram. (c) Fresh 'cores' of cordierite diatexite (from which KB11-336 was sampled) located in situ within heavily weathered host diatexites on the central Kaibobo Peninsula, W Seram. (d) Extremely large boulder of cordierite located in the Wai Tuh, Kobipoto Mountains, containing abundant $\mathrm{cm}$-scale sill+crd+spl schliere. (e) Large banded sill + crd + spl schlieren within a cordierite diatexite boulder, Kobipoto Mountains. (f) Large banded sill $+\mathrm{crd}+\mathrm{spl}$ schlieren within a cordierite diatexite boulder, central Latimor, Ambon. (g) Boulder from the Wai Tuh, Kobipoto Mountains, showing similar contact relations to Tanjung Seri: Intrusion of diatexite (' $\mathrm{Y}$ ') into serpentinised peridotite (' $\mathrm{X}$ '). Note also the large scholle of stromatic metatexite ('Z'). (h) Leucogranite-serpentinite contact relations, Tanjung Seri, Ambon: leucogranite intrudes the peridotites (' $X$ '), which have back-injected the leucogranite (' $\mathrm{Y}$ ') during serpentinisation. (i) Complex leucogranite-serpentinite 
contact at Tanjung Seri (Ambon) showing the intrusive nature of both the leucogranite and serpentinite.

Fig. 3 Field photos of ambonites. (a) Columnar-jointed ambonite exposed on SW Hitu, Ambon. (b) At same locality as ' $m$ ', a xenolith of cordierite diatexite (' $\mathrm{X}$ ') is present in the ambonite. (c) Ambonite exposed in a gorge in northern Hitu (sampling location of AB11-384) showing red garnet and blue cordierite phenocrysts.

Fig. 4 The Kobipoto Migmatite Complex. (a) Schematic diagram showing the relationship between the schlieric cordierite diatexite and residuum-rich metatexite, and their possible derivation from the Tehoru Formation. (b) Photo of garnetsillimanite granulite sample KP11-588 (Pownall, 2015). (c) Large scholle within cordierite diatexite, Wai Tuh, Kobipoto Mountains. (d) Stromatic metatexite from the Wai Tuh, Kobipoto Mountains.

Fig. 5 Photomicrographs of representative thin sections of the Kobipoto Complex and associated leucogranites and volcanic rocks. Mineral abbreviations follow Kretz (1983). (a) Cordierite diatextite SE10-178, Kaibobo Peninsula, W Seram: $\sim 1 \mathrm{~cm}$ sillimanite + spinel schliere. (b) Cordierite diatexite KB11-336, Kaibobo Peninsula, W Seram: small bundles of sillimanite + spinel (the residual migmatite component) with partially pinitised cordierites and biotite. (c) Cordierite diatexite KP11-621, Kobipoto Mountains, central Seram: mm-sized garnets and partially-pinitised cordierites. (d) Cordierite + garnet metatexite KP11-619, Kobipoto Mountains, central Seram: large garnet with biotite reaction rim and abundant pinitised cordierite grains. (e,f) Residual granulite KB11-588, Kobipoto Mountains, central Seram: abundant large garnets and sillimanite separated by ordered reaction microstructures comprising cordierite coronae and cordierite + sillimanite + spinel + ilmenite ( \pm corundum \pm sapphirine) symplectites. Part ' $\mathrm{f}$ ' is shown in cross-polarised light. See Pownall (2015) for additional photomicrographs. (g) Leucogranite AB11026, Latimor, Ambon (cross-polarised light): Titanite and chlorite between large plagioclase phenocrysts. Granophyric $\mathrm{K}$-feldspar-quartz intergrowths are not present in this sample. (h) Ambonite AB11-384, Hitu, Ambon: a large garnet xenocryst. (i) Xenolith within ambonites emplaced in northern Hitu (sampled from same locality as AB11-384): note that the same sillimanite + spinel assemblages are 
present here than in residual granulite sample KP11-588, which is also featured by the schlieren present in the cordierite diatexites (e.g. samples SE10-178, KB11-336, KP11-621) and metatexites (e.g. sample KP11-619).

Fig. 6 Trace element 'spider diagram' of Kobipoto Complex migmatites and related rocks, relative to normal mid-ocean ridge basalt (N-MORB; Sun and McDonough, 1989).

Fig. $7 \quad$ Results of conventional geothermometry for Cr-spinel lherzolite sample KP12-123. The coloured lines show the results of the P-insensitive Brey and Köhler (1990) and Taylor (1998) Cpx-Opx Ca-Mg exchange calibrations, and the Nimis and Taylor (2000) entatite-in-Cpx calibration. The P-T path calculated for UHT granulite sample KP11-588 (Pownall, 2015) is shown by the purple arrow for comparison. The purple oval shows the approximate $\mathrm{P}-\mathrm{T}$ condition $\left(128 \mathrm{O}-1300^{\circ} \mathrm{C}\right.$ in the vicinity of $1 \mathrm{GPa}$ ) interpreted for $\mathrm{KP} 12-123$ (see text). The peridotite phase diagram and mol.\% melt isopleths (traced from Thompson and Gibson, 2000) are not constructed specifically for sample KP11-123, but for the extensively-studied 'KLB-1' anhydrous lherzolite from numerous experiments (Takahashi, 1986; Takahashi et al., 1993; Herzberg and Zhang, 1996).

Fig. 8 Representative cathodoluminescence (CL) images of zircons from (a) SE10-178; (b) KB11-336; (c) AB11-026; (d) KP11-588; (e) KP11-619; (f) KP11-621; and (g) AB11-384. All images are presented at the same scale $(100 \mu \mathrm{m}$ scale bar, bottom right). The red analytical spots are accurately sized and located, as judged from ablation pits visible in post-analytical reflected light photomicrographs. Phanerozoic zircon rims and core regions are annotated with ${ }^{206} \mathrm{~Pb} /{ }^{238} \mathrm{U}$ ages; and Proterozoic

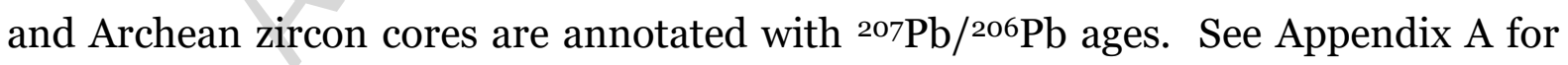
the full dataset and additional CL images.

Fig. 9 'Cartoons' of selected zircon grains that illustrate the relationships between different growth regions: $\mathbf{R}_{\mathbf{m}}$ refers to either magmatic or metamorphic zircon rims; $\mathbf{C}_{\mathbf{m}}$ refers to either magmatic or metamorphic cores; $\mathbf{C}_{\mathbf{d}}$ refers to detrital zircon cores; $\mathbf{R}_{\mathbf{2}}$ refers to a second CL-bright rim between $\mathrm{R}_{\mathrm{m}}$ rims and $\mathrm{C}_{\mathrm{d}}$ cores that 
are present in some grains; and $\mathbf{R}_{\mathbf{o}}$ refers to very thin CL-bright overgrowths (but were too small to analyse). Compare with Figure 8.

Fig. 10 Tera-Wasserburg diagrams for SHRIMP U-Pb analyses of Neogene and Quaternary zircon for samples (a) SE10-178; (b) KB11-336; (c) AB11-026; (d) KP11-588; (e) KP11-619; (f) KP11-621; and (g) AB11-384. Each plot displays the most recent event to be recorded in each sample. Mean ${ }^{206} \mathrm{~Pb} /{ }^{238} \mathrm{U}$ ages are quoted to $95 \%$ confidence, and error ellipses are drawn at $68.3 \%$ confidence. The ages plotted are uncorrected for common $\mathrm{Pb}$. Regression lines are displayed, but due to the tight clustering of the data close to the concordia, intercept ages have too great an error to be of use. A discordant analysis (spot 13.2 for AB11-384, part g) is shown in grey. The regression line for part ( $\mathrm{f}$ ) is anchored to the common ${ }^{207} \mathrm{~Pb} /{ }^{206} \mathrm{~Pb}$ ratio of 0.836 . Part (d) is reproduced, with modification, from Pownall et al. (2014). MSWD-Mean square of weighted deviates. See Appendix A for the full dataset.

Fig. 11 Th versus U plots of zircon analysed by SHRIMP from (a) SE10-178; (b) KB11-336; (c) Ab11-026; (d) KP11-588; (e) KP11-619; (f) KP11-621; (g) AB11-384; (h) All Kobipoto Mountain samples; (i) all Kaibobo Peninsula and Ambon cordierite diatexites. Grey dashed lines contour fixed Th/U ratios. Analyses are coloured according to the type of zircon analysed: black circles for detrital cores (Cd); grey circles for purely magmatic grains $\left(\mathrm{C}_{\mathrm{m}}\right)$; white circles for metamorphic/magmatic overgrowths ( $\mathrm{Rm}$ ); and red diamonds for CL-bright ' $\mathrm{R}_{2}$ ' zones. See Appendix A for the full dataset.

Fig. 12 Concordia diagrams for SHRIMP U-Pb analyses of zircon from (a) KP11-621; (b) AB11-384; (c) KP11-588; (d) SE10-178; (e) KB11-336; (f) AB11-026; and (g) KP11-619. Numbered points on the concordia are ages in Ma. Error ellipses are drawn at $68.3 \%$ confidence. See Appendix A for the full dataset.

Fig. 13 Plot of Late Triassic-Early Jurassic (215-173 Ma) ${ }^{206} \mathrm{~Pb} /{ }^{238 \mathrm{U}}$ ages for $\mathrm{R}_{2}$ zircon from the Kobipoto Mountains granulite-facies migmatites. The brown region shows the narrowest permitted range of $\mathrm{R}_{2}$ ages. The blue region shows the youngest extent (oldest permitted limit) of the detrital zircon $\left(\mathrm{C}_{\mathrm{d}}\right)$ population. Error bars drawn at $95 \%$ confidence. 
Fig. 14 Histogram (top) and relative probability curves (bottom) of SHRIMP $\mathrm{U}-\mathrm{Pb}$ zircon ages for detrital cores $\left(\mathrm{C}_{\mathrm{d}}\right)$ of all samples. Phanerozoic detrital zircons are plotted using their ${ }^{206} \mathrm{~Pb} /{ }^{238} \mathrm{U}$ ages; and Proterozoic and Archean detrital zircons are plotted using their ${ }^{207} \mathrm{~Pb} /{ }^{206} \mathrm{~Pb}$ ages. The scale of both axes change at $500 \mathrm{Ma}$. Note the similarity in the detrital zircon age distribution recorded here for Seram with other islands of the Banda Arc, presented by Zimmermann and Hall (2016).

Fig. 15 Comparison of all ${ }^{206} \mathrm{~Pb} /{ }^{238} \mathrm{U}$ ages. Ages calculated for individual analytical spots are shown with $1-\sigma$ error bars. Horizontal coloured bars relate to the mean weighted ${ }^{206 \mathrm{~Pb}} /{ }^{238} \mathrm{U}$ ages for each of the 7 samples, offset by error bars at $95 \%$ confidence.

Fig. 16 Tectonic reconstructions for SE Asia and Eastern Gondwana. (a) Reconstruction during the Late Triassic (c. $215 \mathrm{Ma}$ ) adapted from Gunawan et al. (2012, 2014) and based also on interpretations from Hill and Hall (2003), Metcalfe (1996, 2011), and Zimmermann and Hall (2016). The Argo and Banda blocks have been interpreted by Hall (2012) to have rifted from the western Australian margin in the Jurassic, leaving attached to Australia the continental promontory of the Sula Spur (SS) of which Seram and Buru are parts. Based on the new U-Pb zircon ages presented by this study (ages of ' $\mathrm{R}_{2}$ ' zircon; Fig. 13), significant metamorphic/magmatic events are identified to have occurred from 215-173 Ma within the Sula Spur due most likely to lithospheric extension the onset of rifting of the Banda blocks from the southern margin of the Sula Spur. The route of sediment supply (brown dotted line) from Western Australia and New Guinea is purely schematic. (b) Late Jurassic reconstruction (155 Ma), adapted from Hall (2012). Note how spreading of the Proto-Banda Sea is driven by the rifting of the Banda and Argo blocks, which commenced before $160 \mathrm{Ma}$. We suggest, based on the zircon ages presented in Figure 13, that the extension that culminated in this rifting event occurred from 215-173 Ma, and therefore that rifting likely occurred slightly sooner, at c. 170 Ma. Ex P-Exmouth Plateau; Sc P-Scott Plateau. (c) Tectonic reconstruction of Eastern Indonesia at $15 \mathrm{Ma}$, adapted from Hall (2012), depicting southeastward rollback of the Banda Arc into the Jurassic Banda Embayment. The yellow star shows the proposed location of western Seram at that time. All parts of 
this figure use the same colour scheme: Oceanic crust is shown in dark blue (older than $120 \mathrm{Ma}$ ) and mid-blue (younger than $120 \mathrm{Ma}$ ); submarine arcs and oceanic plateaus are shown in pale blue; volcanic island arcs, ophiolites, and material accreted along plate margins are shown in green. Note scale and orientation changes between each part of the figure. See Fig. 15 of Pownall et al. (2017) for a series of reconstructions from SE Asia-Australia collision (23 Ma) to exhumation of the Kobipoto Complex diatexites on Ambon (3.4 Ma), and extension of the Weber Deep (Pownall et al., 2016; Hall et al., 2017) during progressive Banda slab rollback.

Fig. 17 Schematic tectonic model for Miocene extension of the northern Banda Arc (modified from Pownall, 2015). (a) Extension at or soon before 16 Ma drove exhumation of hot $\left(1280-1300^{\circ} \mathrm{C}\right)$ lherzolites to shallow ( $\left.\sim \mathrm{GPa}\right)$ depth, driving metamorphism and melting of adjacent continental crust under UHT conditions. (b) Subsequent to the extensional event at $16 \mathrm{Ma}$, hot lherzolites and adjacent diatexites of the Kobipoto Complex were exhumed to shallower levels during further periods of extension (at c. 5.5 Ma in western Seram, and at c. 3.5 Ma on Ambon). This final high- $T$ exhumation overprinted hanging-wall Tehoru Formation rocks with sillimanite-grade shear zone described as the Taunusa Complex. Note that both parts of this figure post-date the Late Triassic-Early Jurassic event, recorded by the $\mathrm{R}_{2}$ zircon, that may have been driven also by extension proceeding rifting within the NW Australian continental margin (Fig. 16b).

Fig. 18 Synthesis of $P-T$ data for Kobipoto Complex granulites and adjacent lherzolites, demonstrating how it is feasible that UHT conditions were attained by hot mantle exhumation. The $P-T$ path of the UHT granulite sample KP11-588 and the garnet-out and biotite-in reaction lines are from Pownall (2015). The $P-T$ path of the lherzolite sample KP12-123 is from Fig. 7. Numbered coloured circles are U$\mathrm{Pb}$ zircon ages in Ma for the Kobipoto Mountains granulites (16 Ma), and Kaibobo Peninsula diatexites, western Seram (5.5 Ma).

\section{TABLES}


Table 1: A summary of previously-published ages, and new results, for igneous rocks and Kobipoto Complex migmatites from Seram and Ambon.

Table 2: Major- and trace-element abundances for samples of Kobipoto Complex migmatite, ambonite, and leucogranite, determined by X-ray Fluorescence (XRF).

Table 3: Major- and trace-element abundances for samples of Kobipoto Complex lherzolites (and serpentinised lherzolites) determined by X-ray Fluorescence (XRF).

Table 4: Representative mineral analyses of lherzolite KP12-123 from the Kobipoto Mountains. 


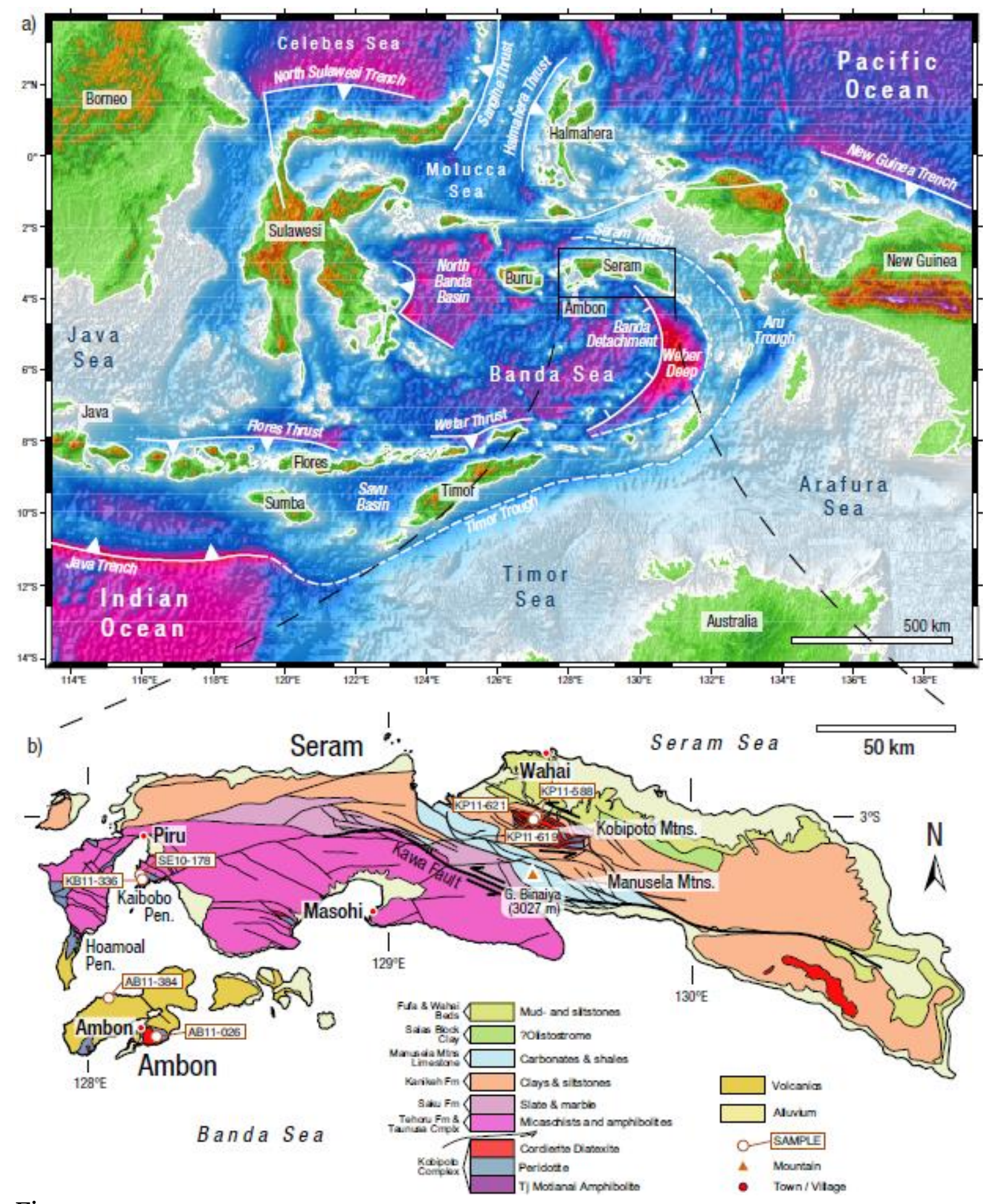

Figure 1 

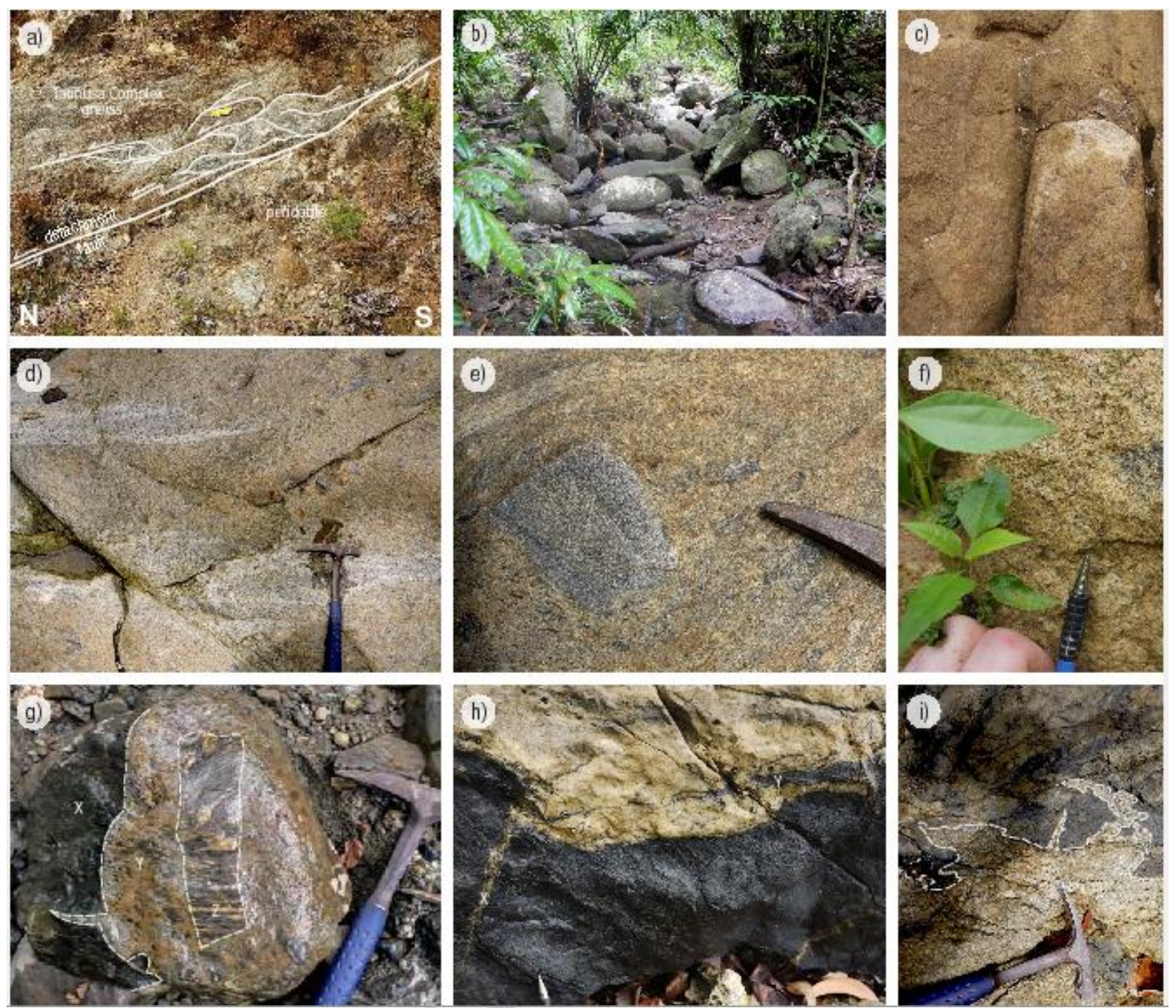

Figure 2 

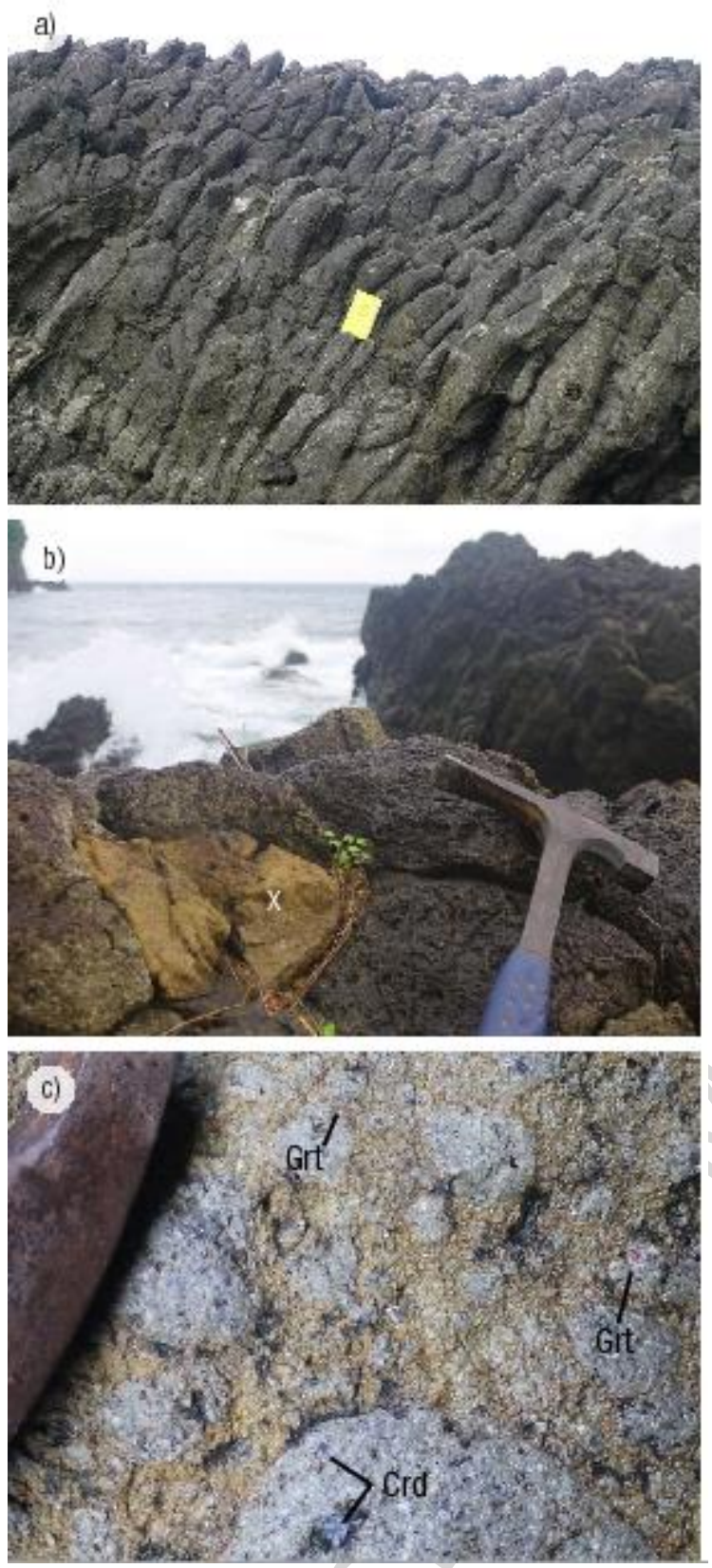

Figure 3

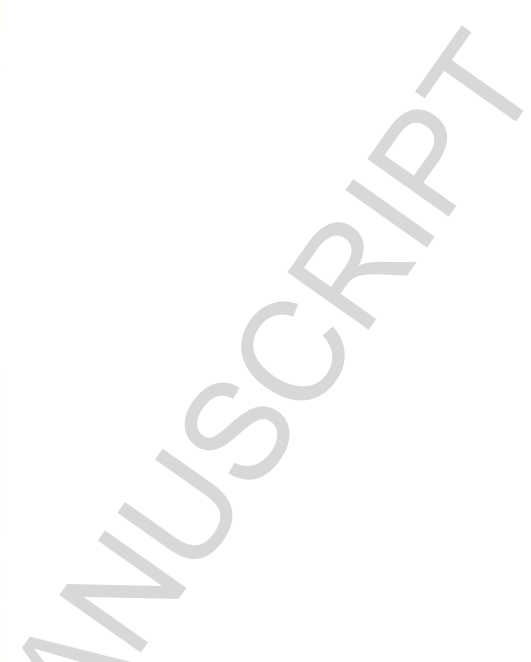




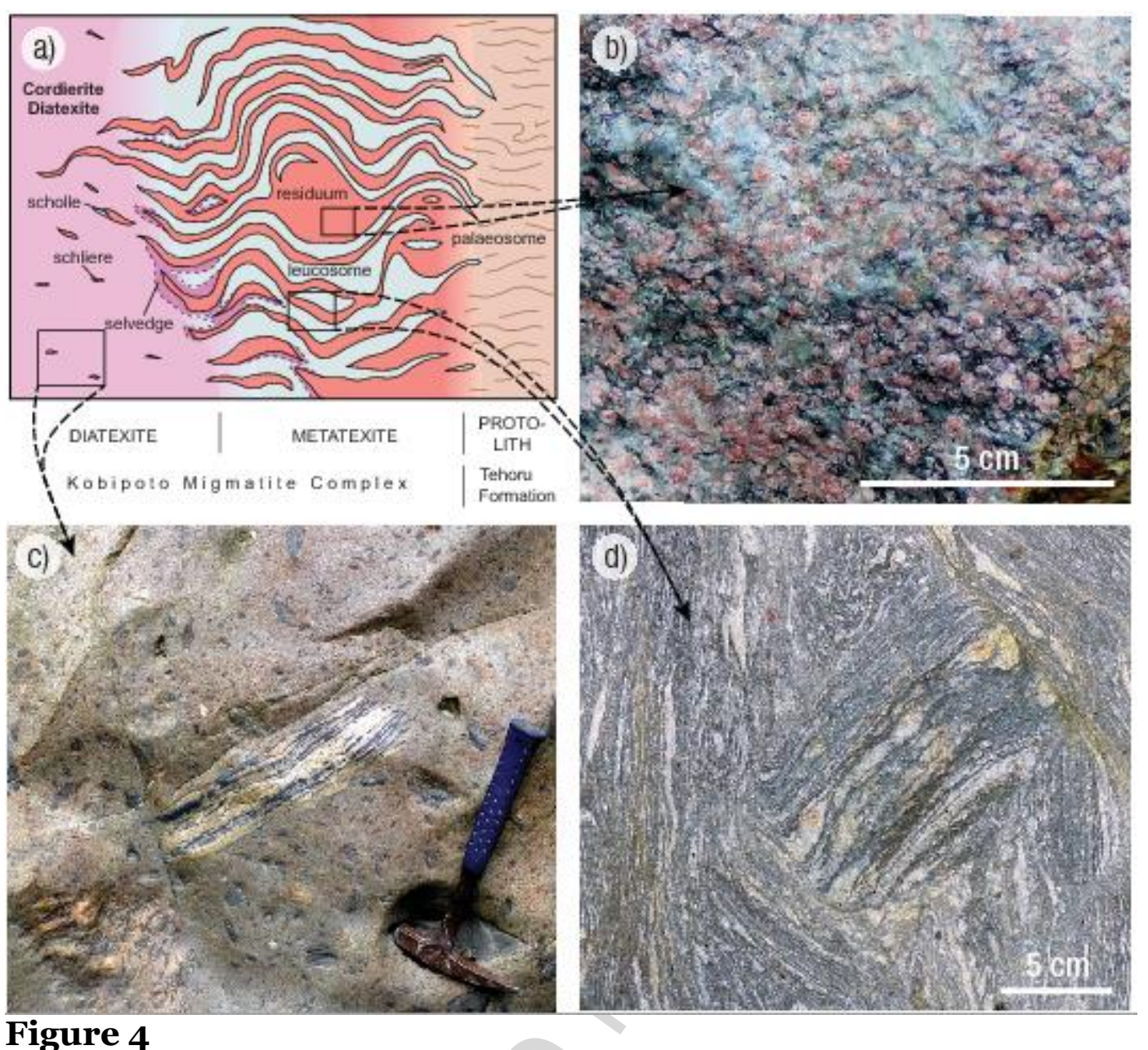

\section{Figure 4}

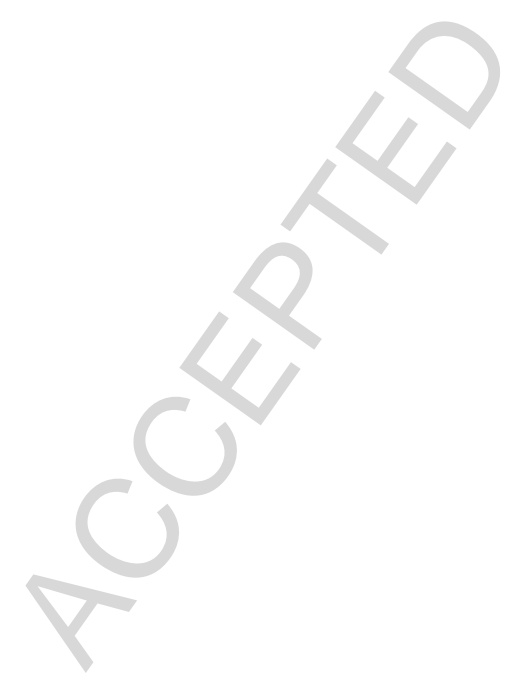



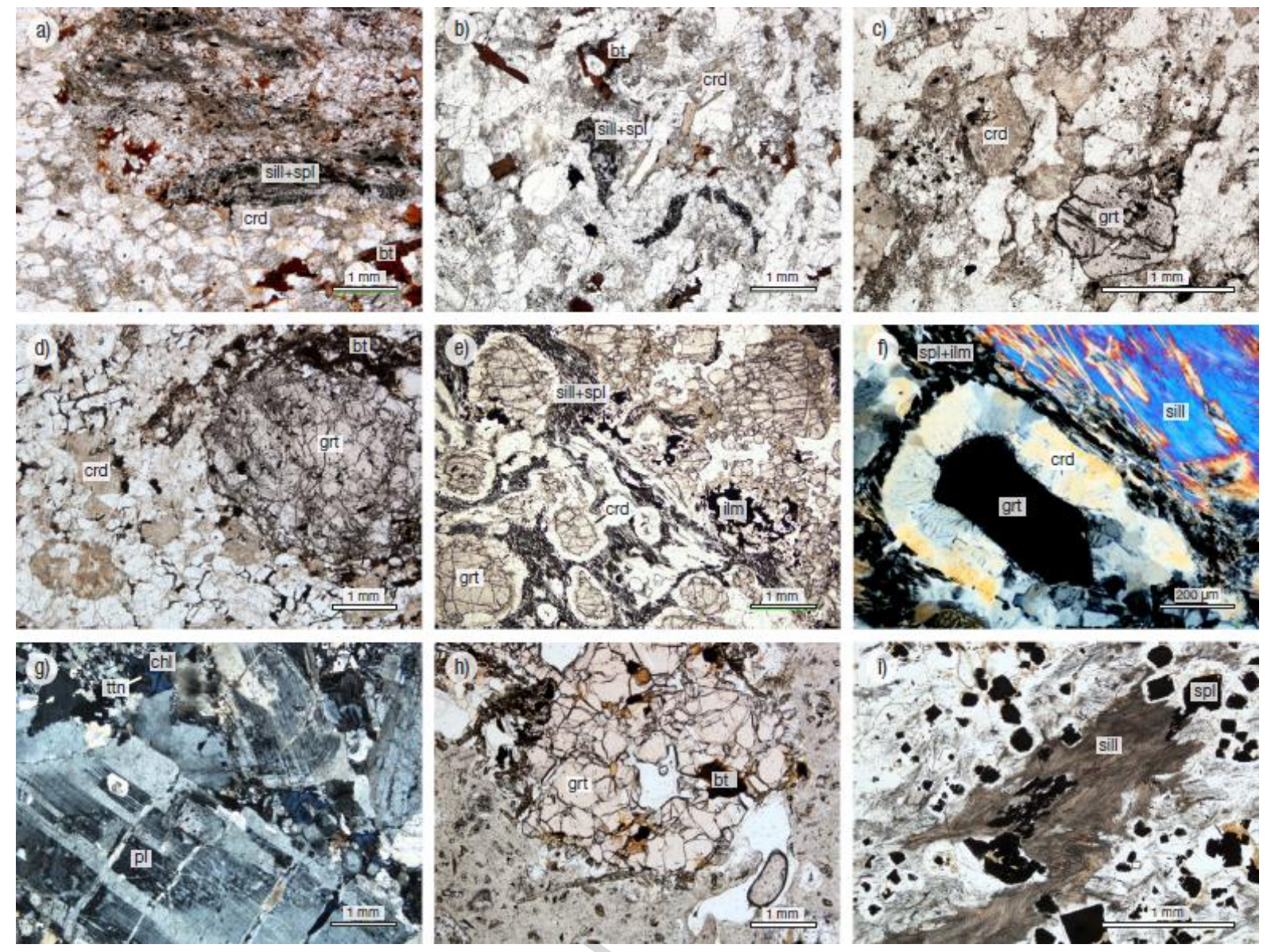

Figure 5 


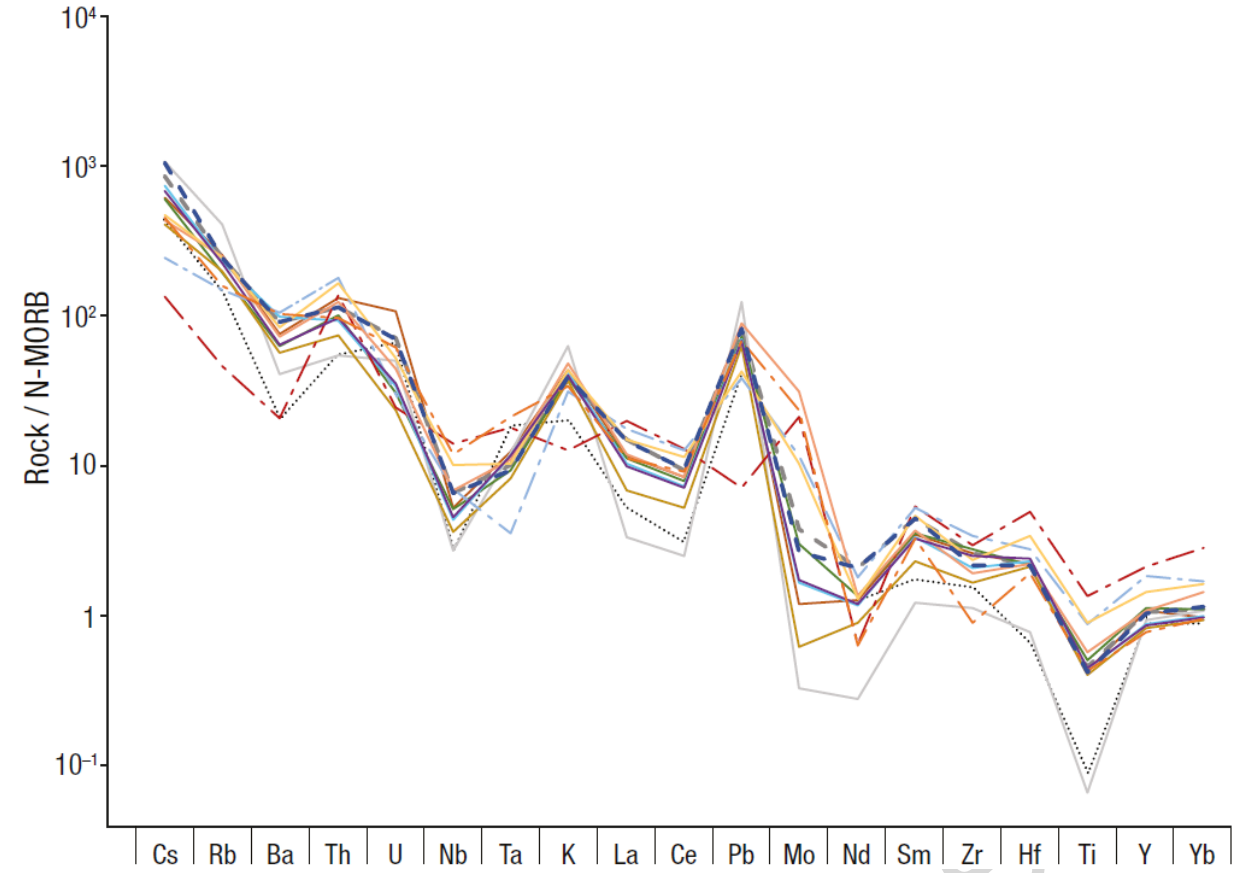

Kobipoto Mtns residual granulites

----- KP11-588

- KP11-619

---- KP12-133

Kobipoto Mtns diatexites

KP11-621

KP11-624

Kaibobo Peninsula diatexites

SE10-178

KB11-218

KB11-336A

KB11-367

Ambon diatexites

AB11-100

AM10-167

Ambon leucogranite

AB....... AB11-026

Ambonites

- - - AB11-384

- - - SE10-8B

Figure 6 


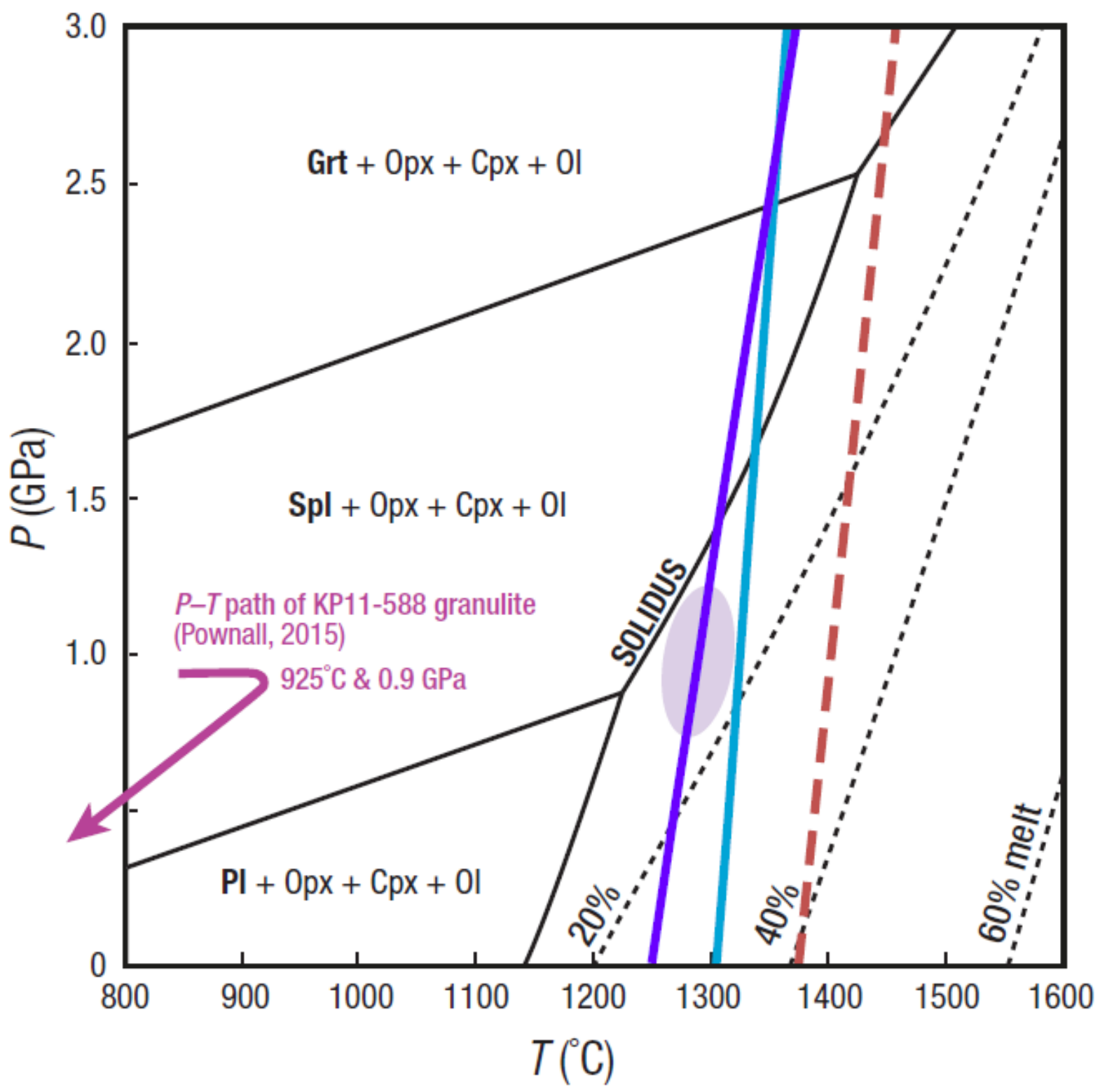

B
Brey and Köhler (1990) $\square$ Taylor (1998) $\_$Cpx-0px Ca-Mg exchange geothermometers

- - Nimis and Taylor (2000) — En-in-Cpx geothermometer

Figure 7 

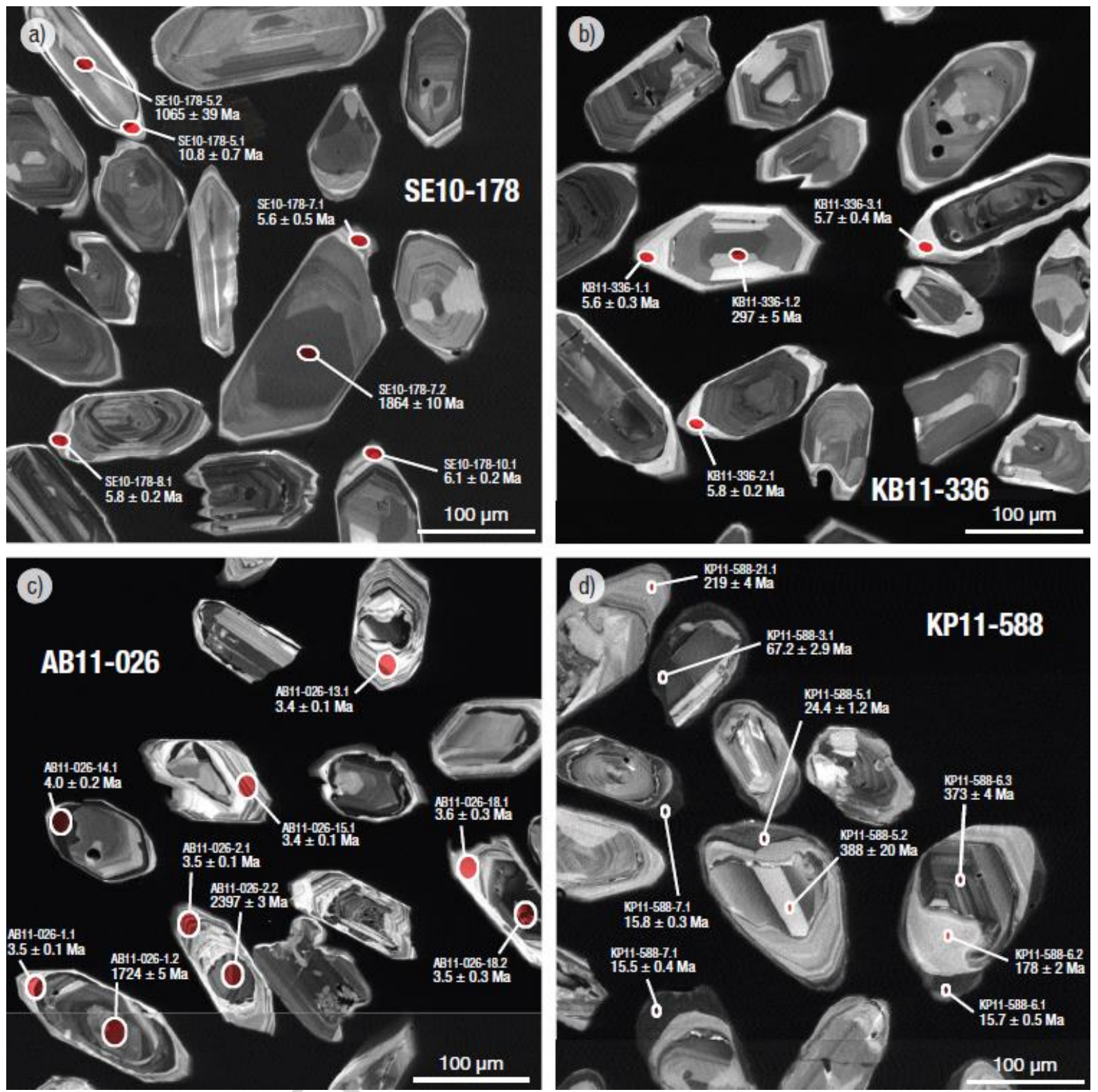

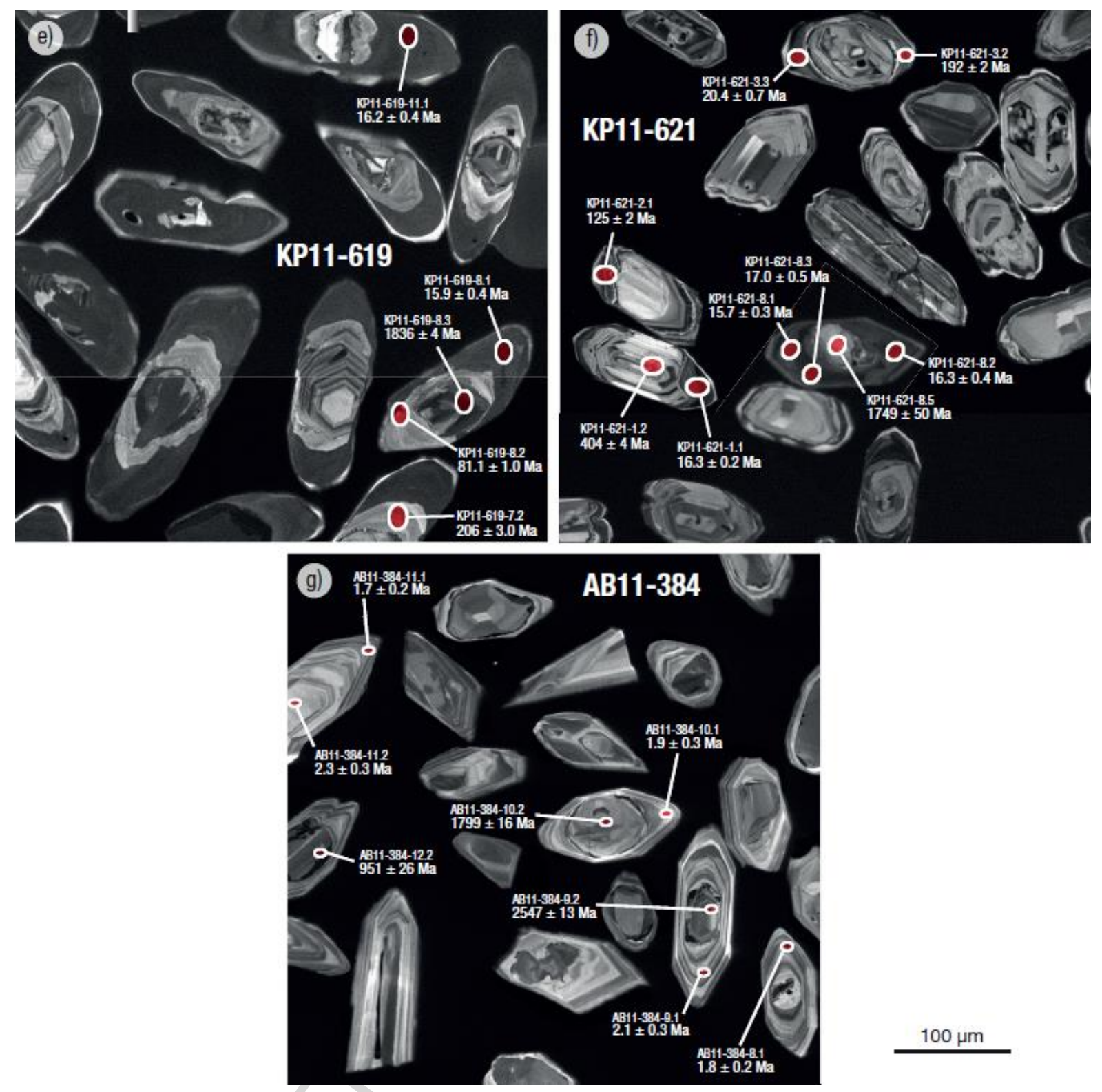

Figure 8 


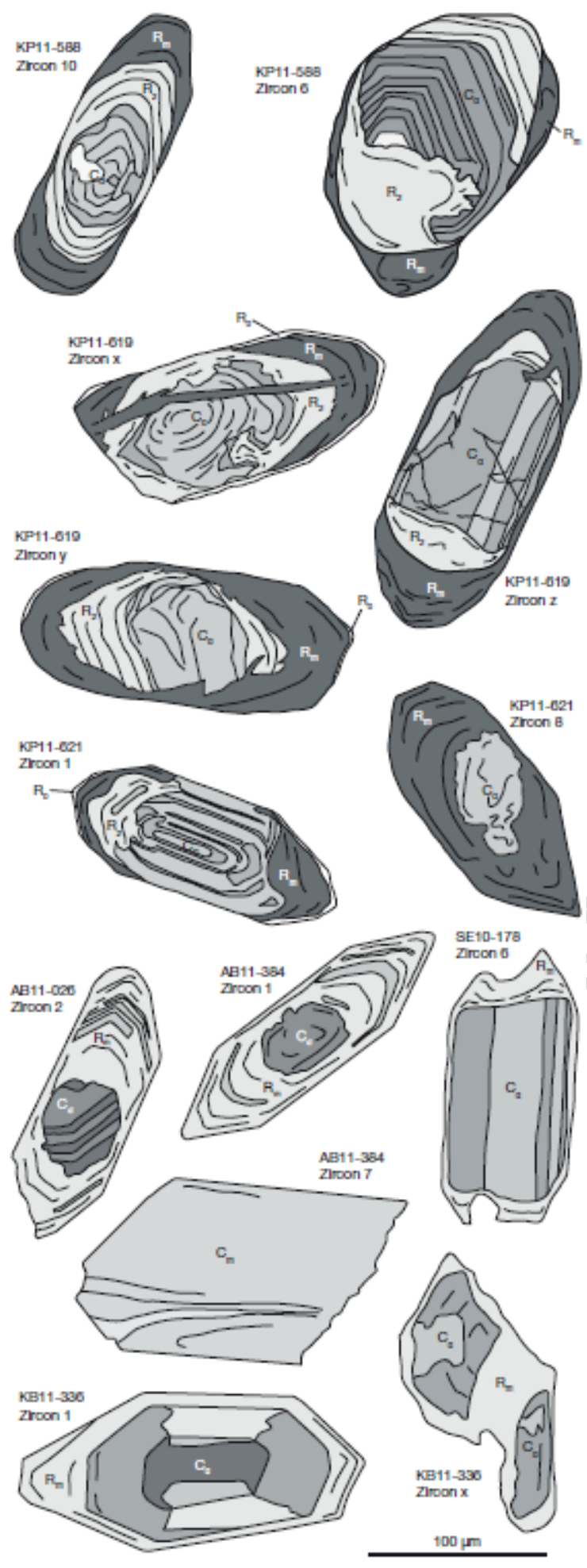

Figure 9 

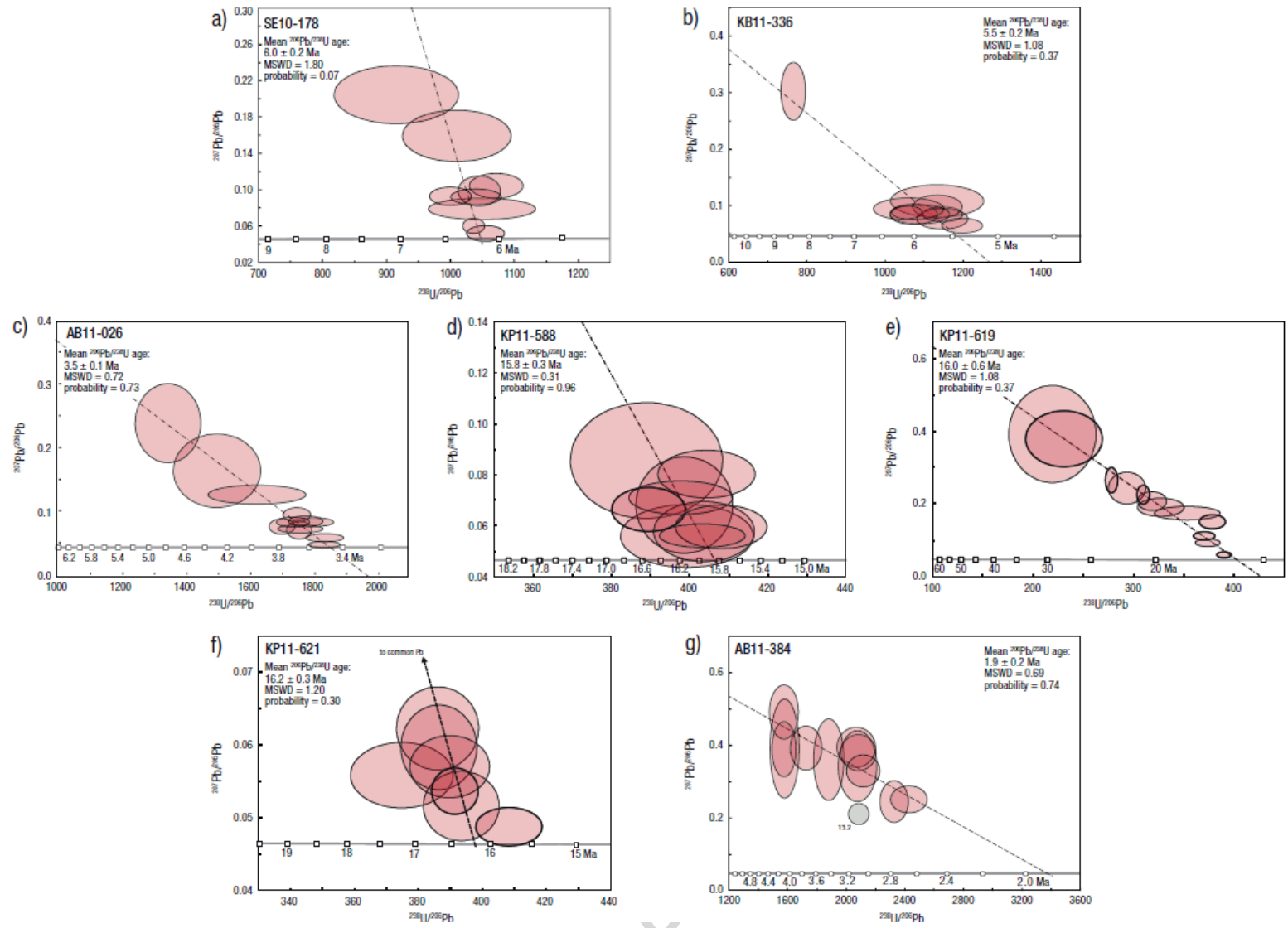

Figure 10 

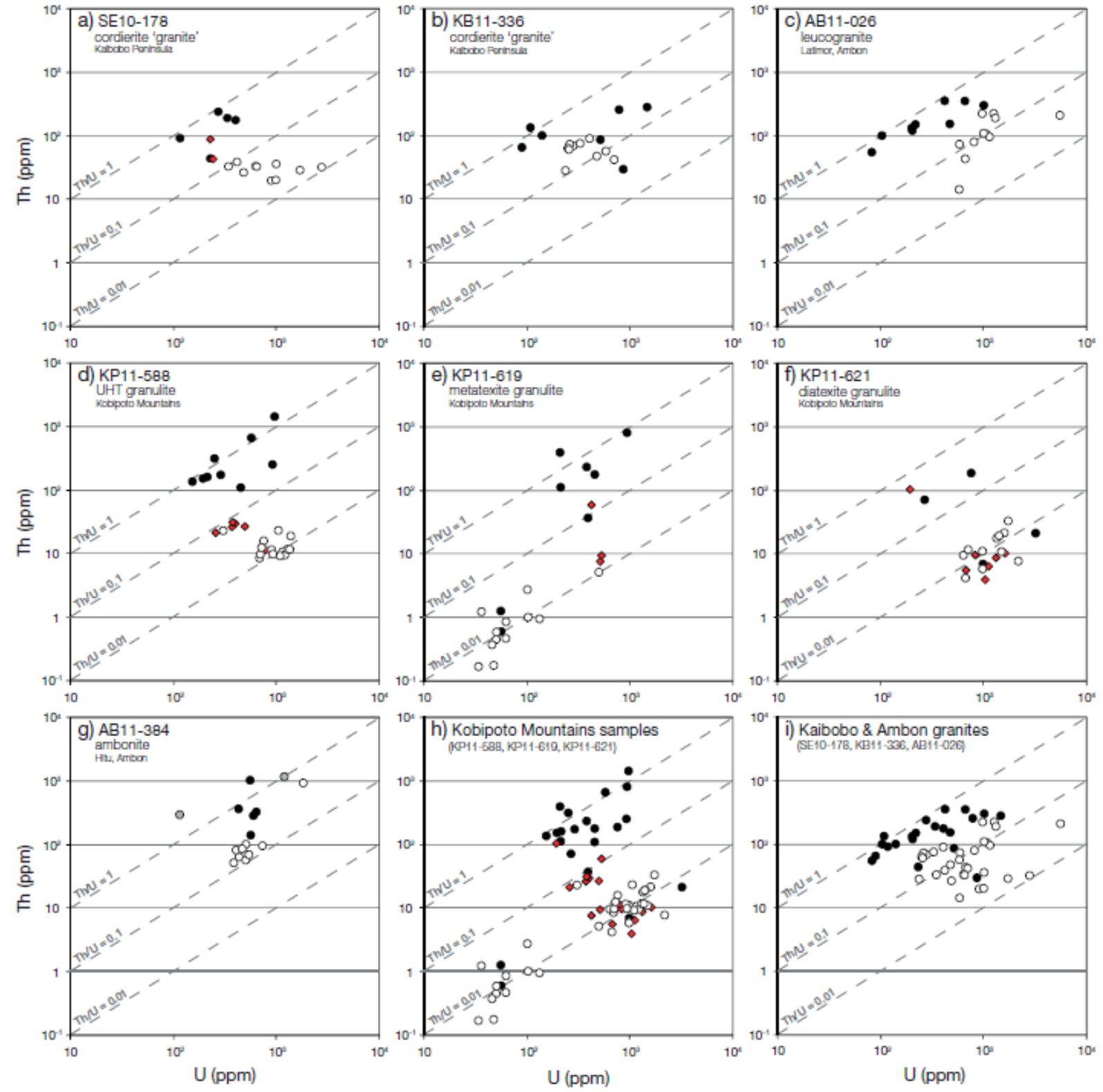

- $\mathrm{C}_{\mathrm{d}}$ core

$\circ \mathrm{C}_{\mathrm{m}}$ grain

o $R_{m}$ rim

- $\mathrm{R}_{2}$ zone

Figure 11 

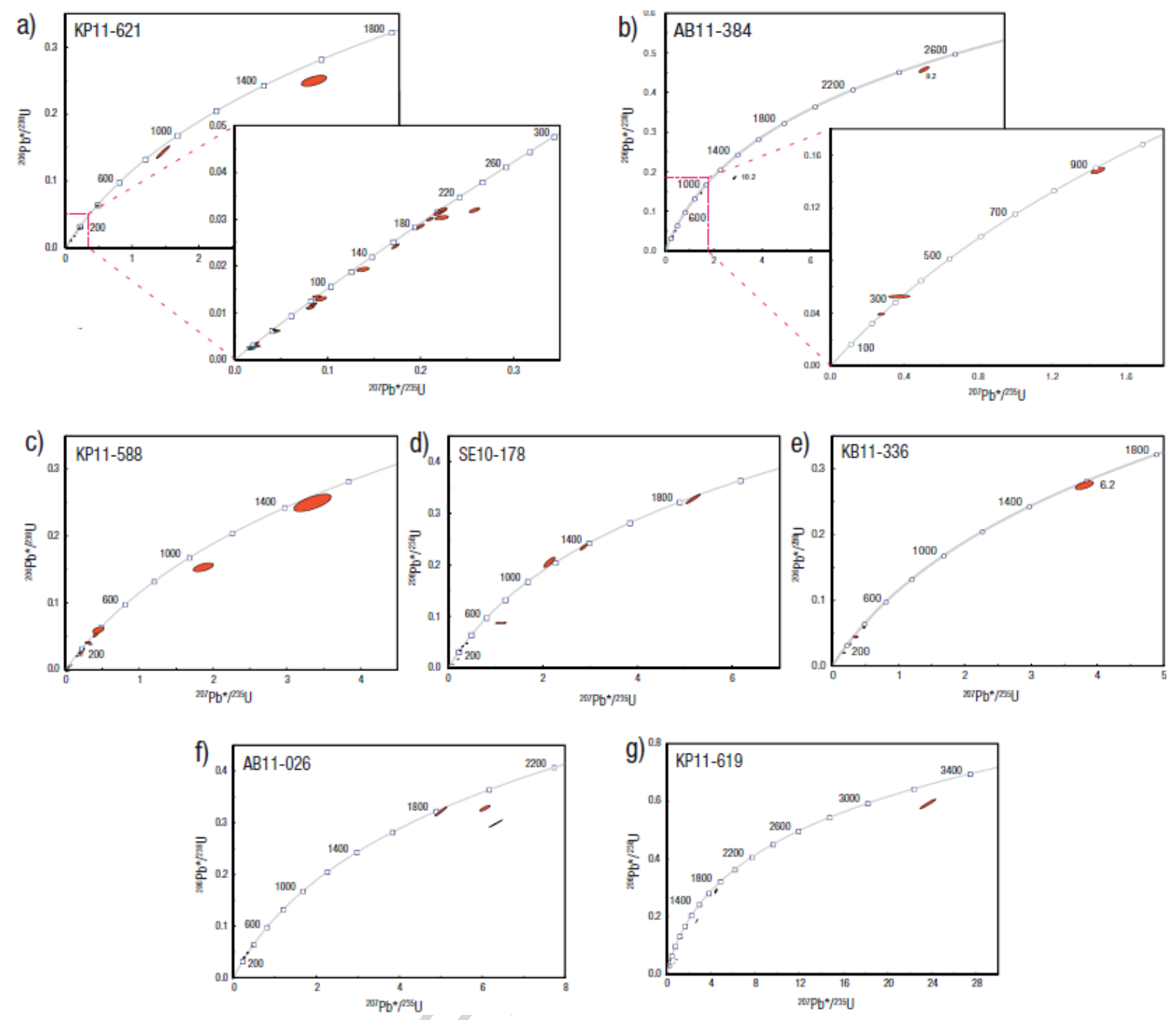

Figure 12 


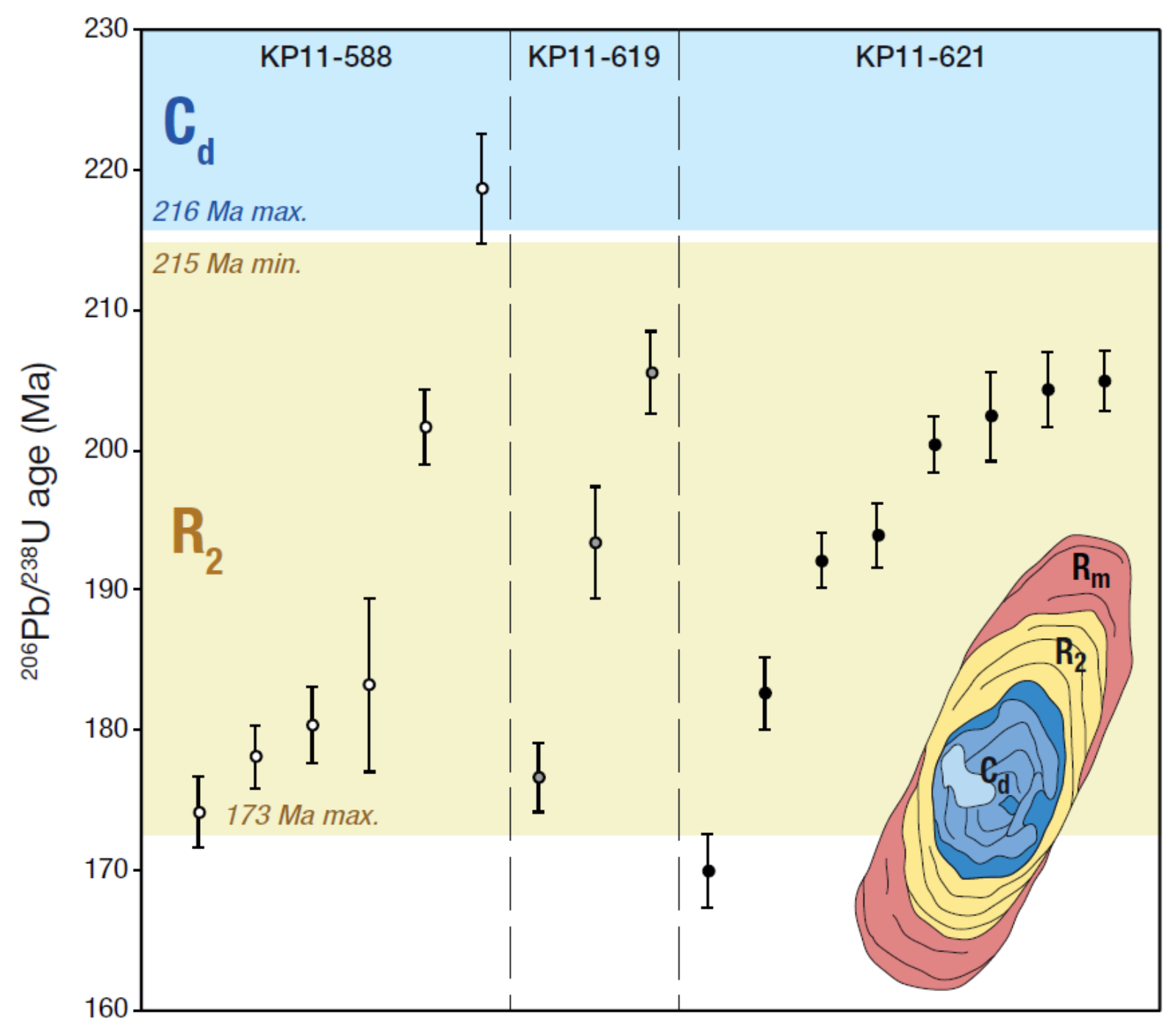

Figure 13 

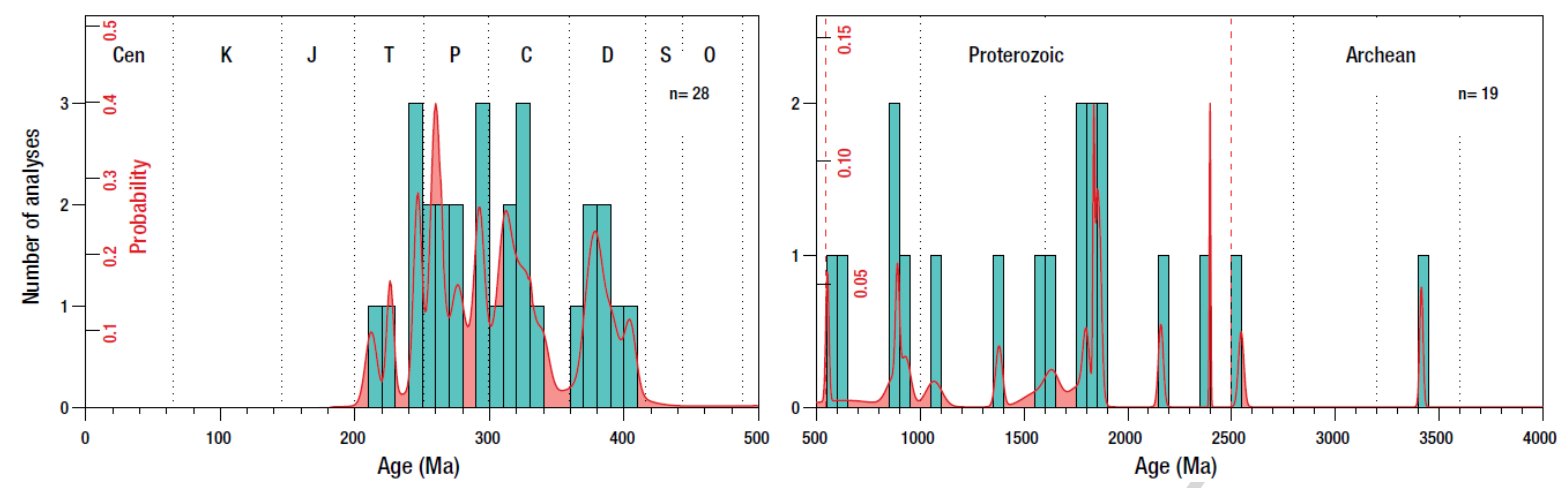

Figure 14 


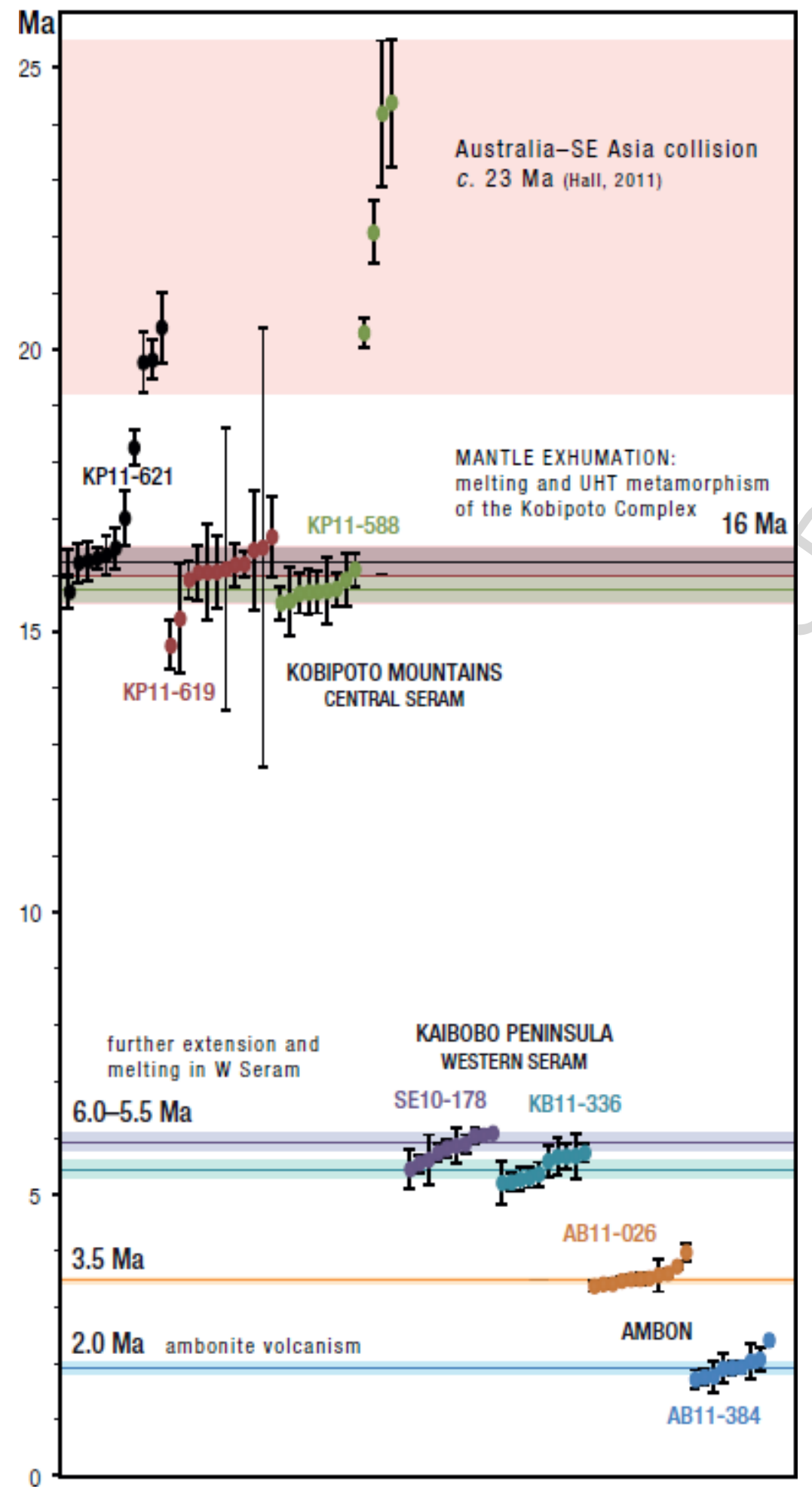

Figure 15 

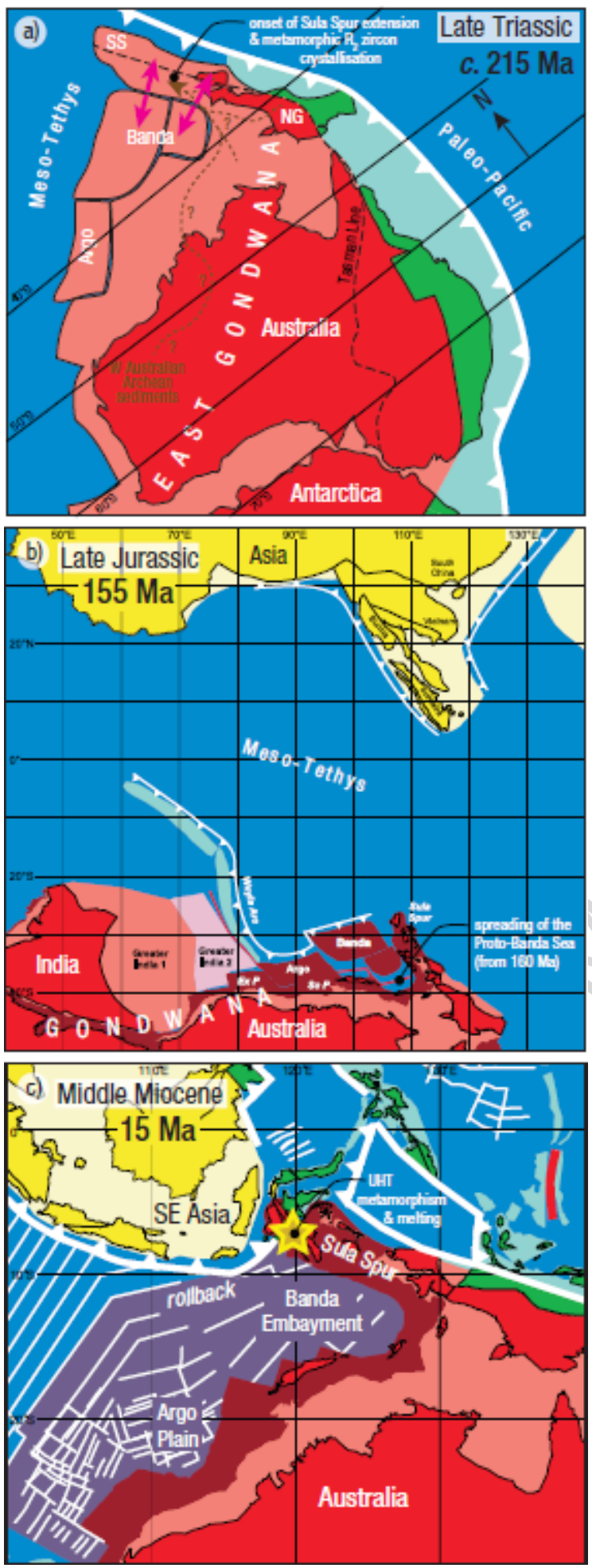

Figure 16 
a) $16 \mathrm{Ma} N \mathrm{NNE}$

S E R A M

SSW

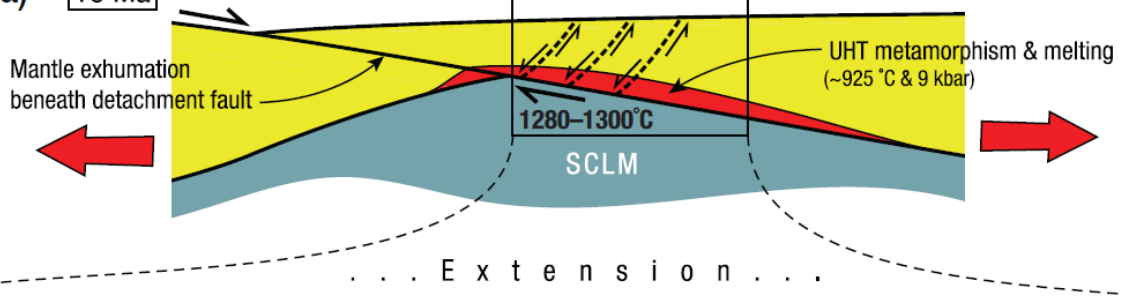

b) +STRKE-SLP Motion Kobipoto Mtns

W Seram

Ambon Ambonite

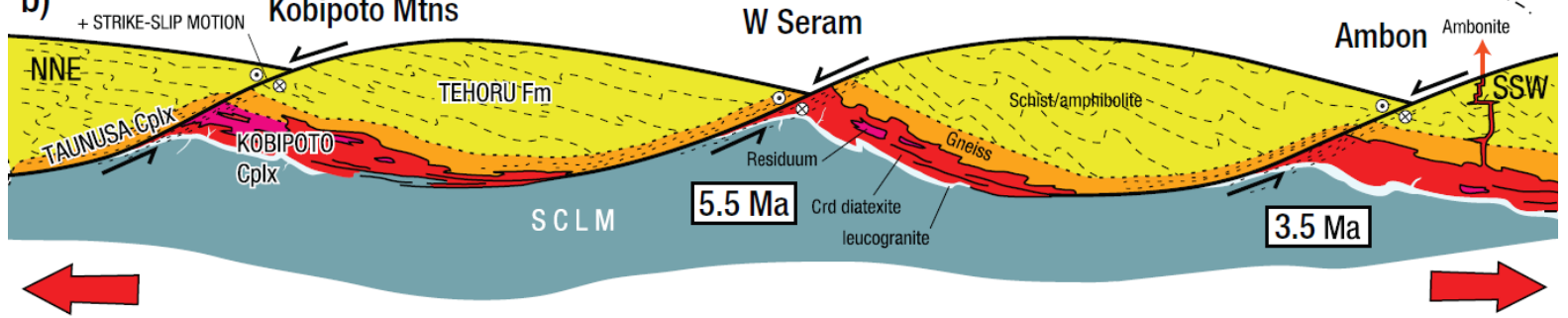

Figure 17 


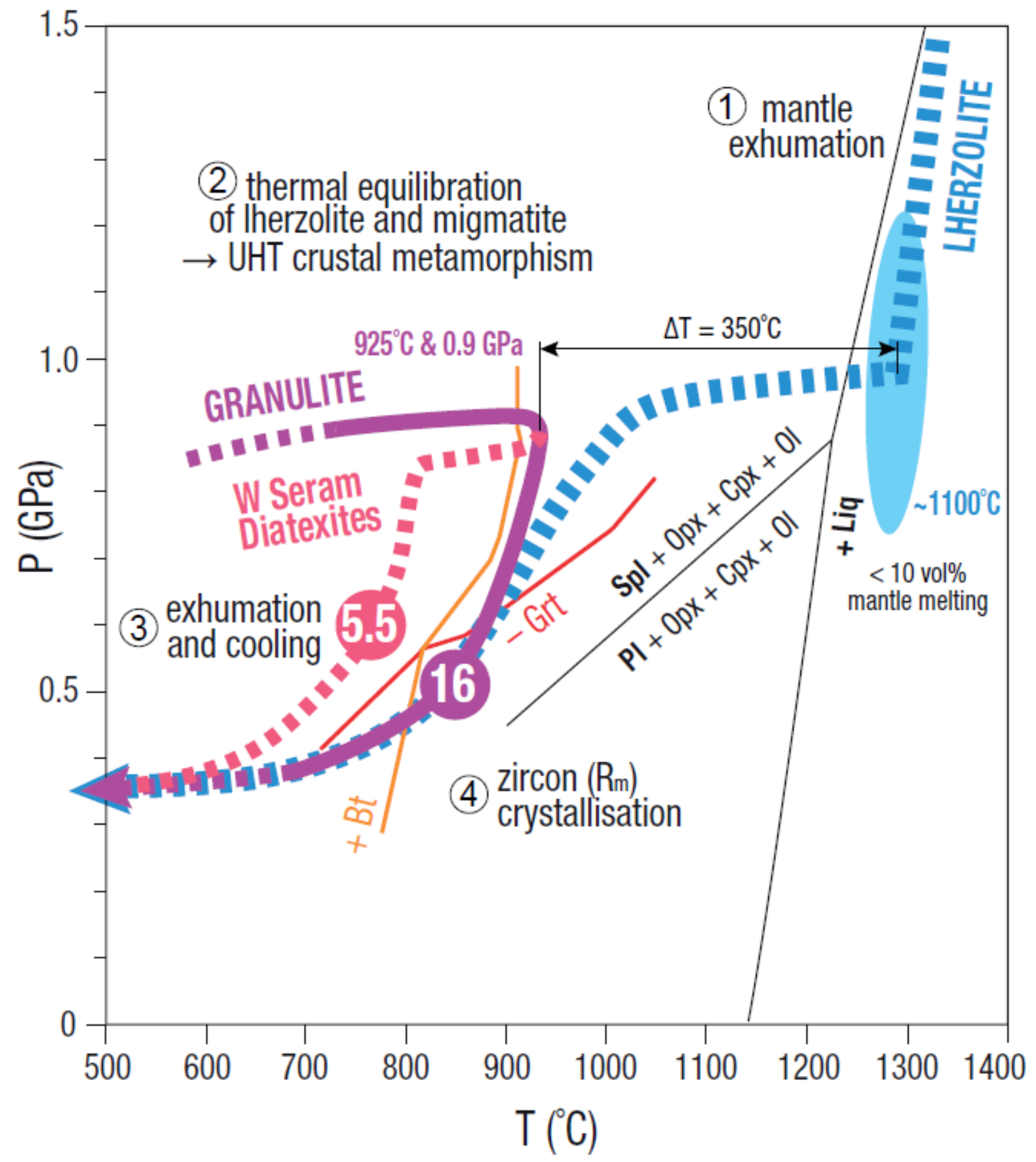

Figure 18 
Table 1

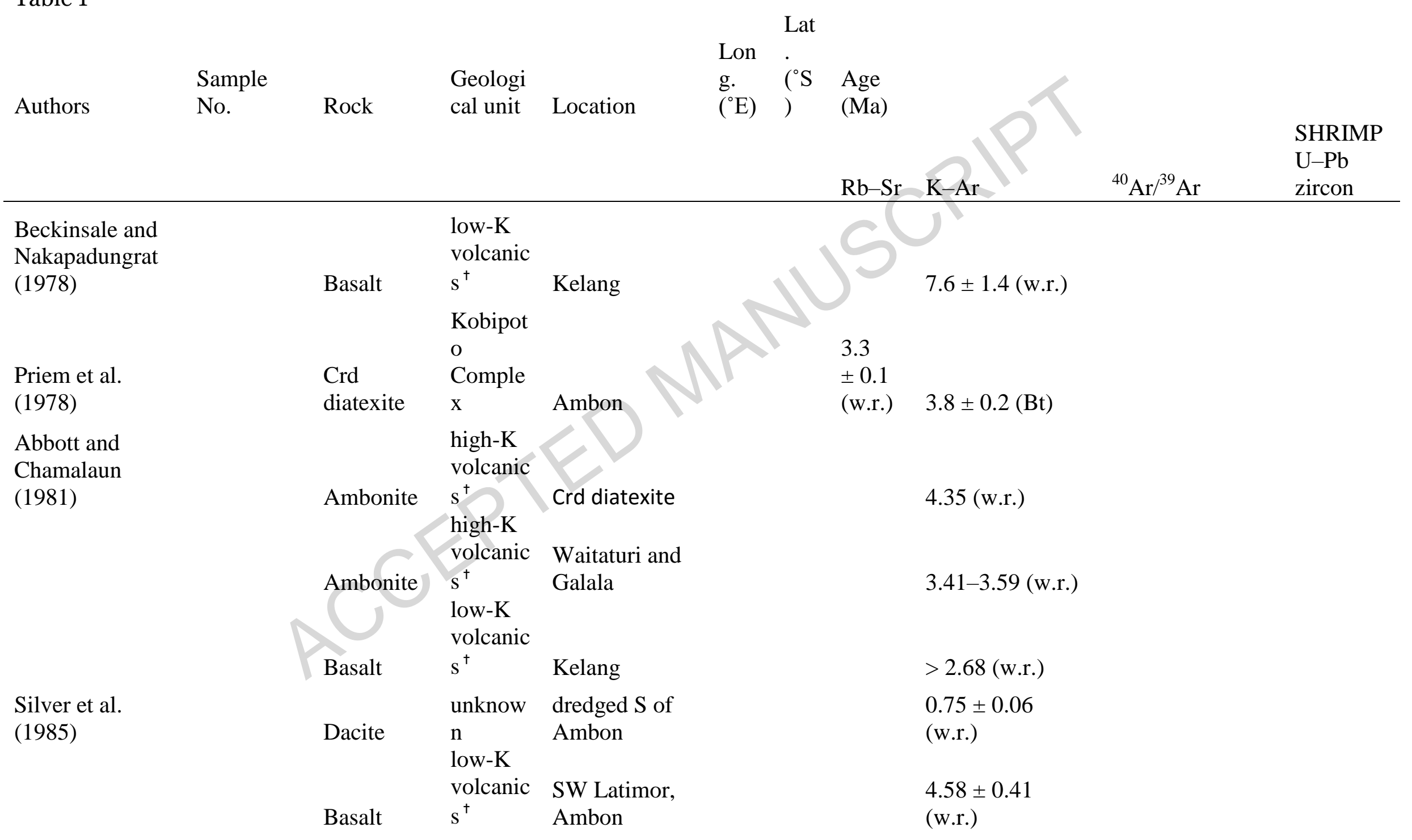




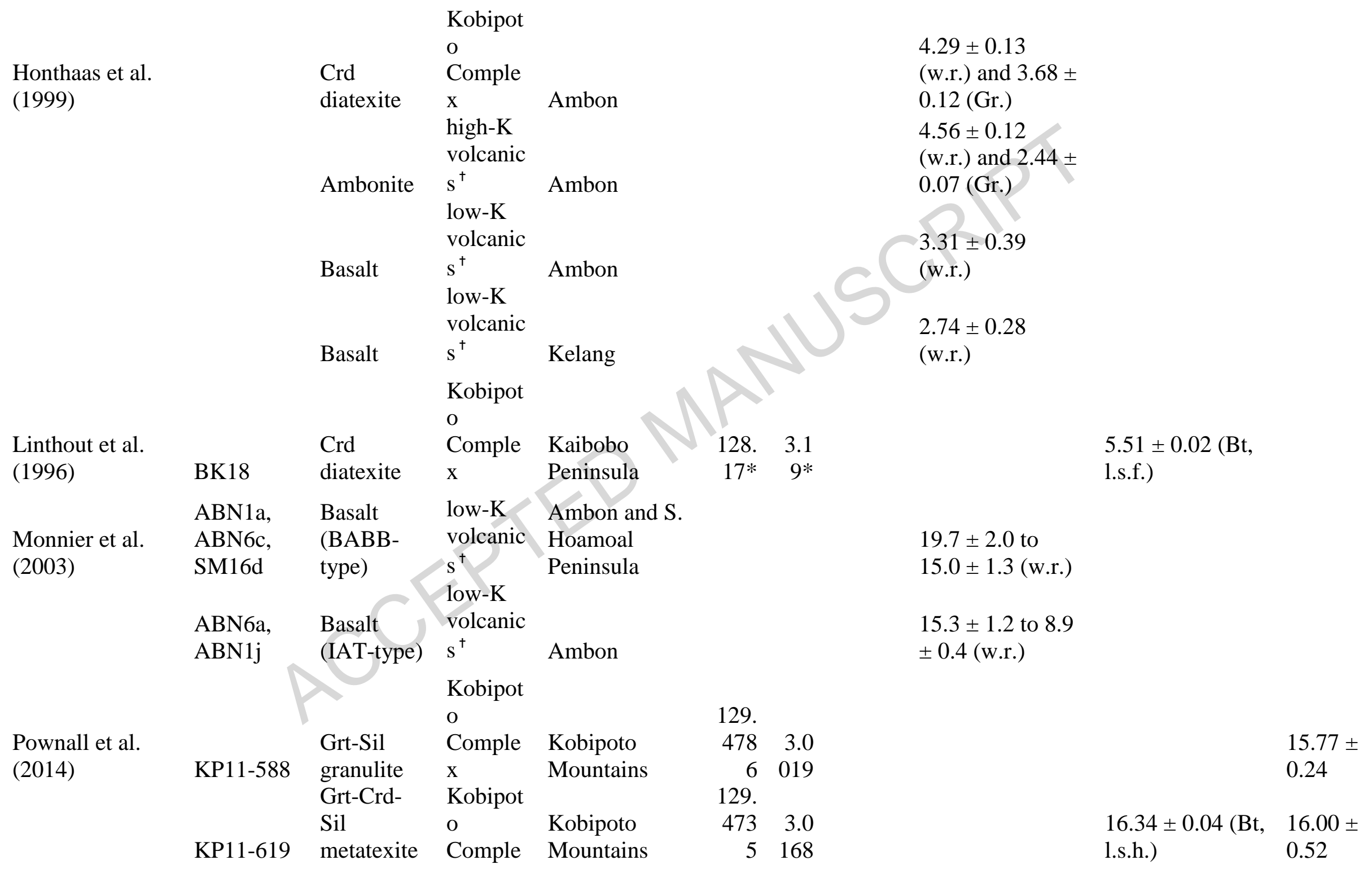




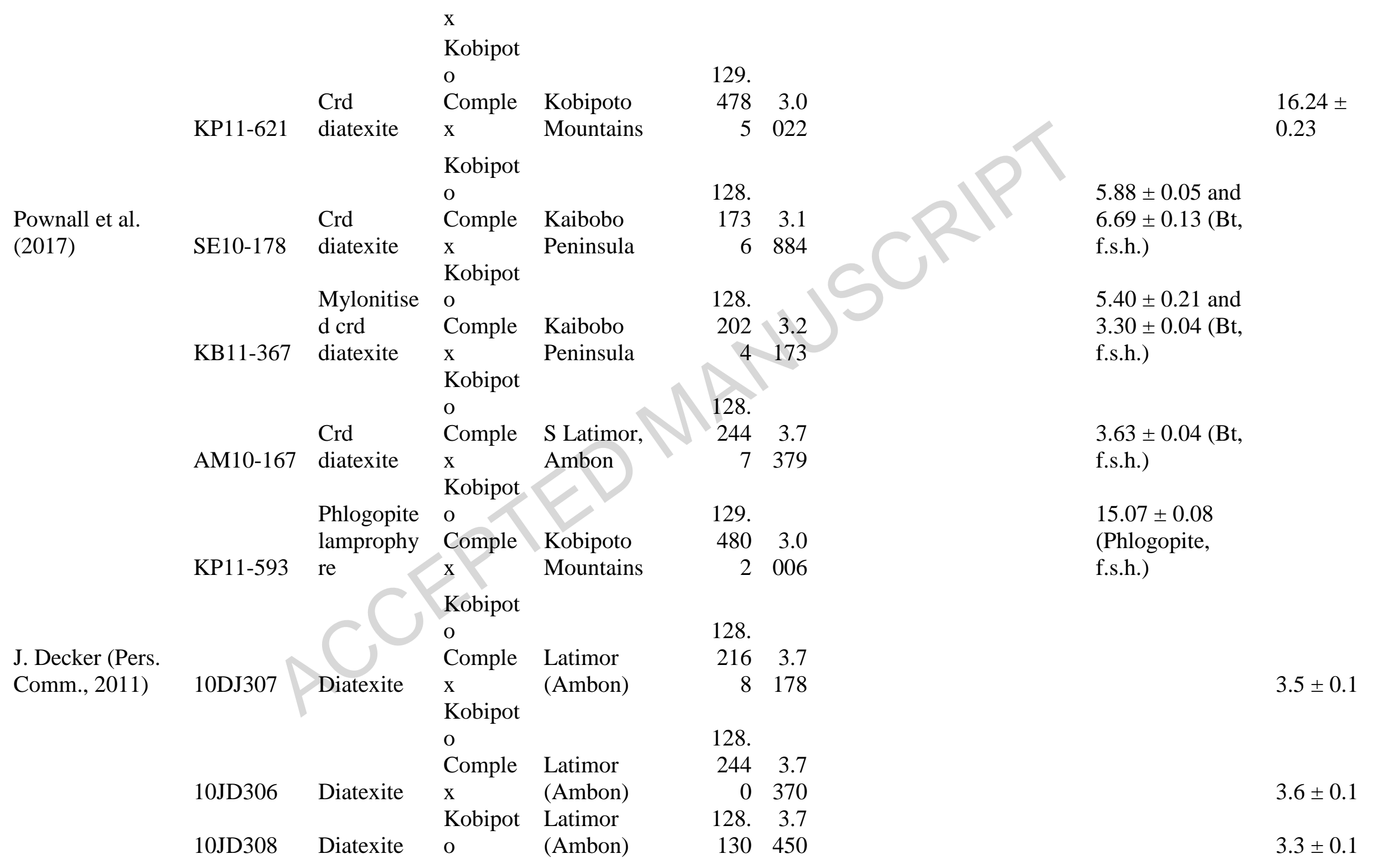




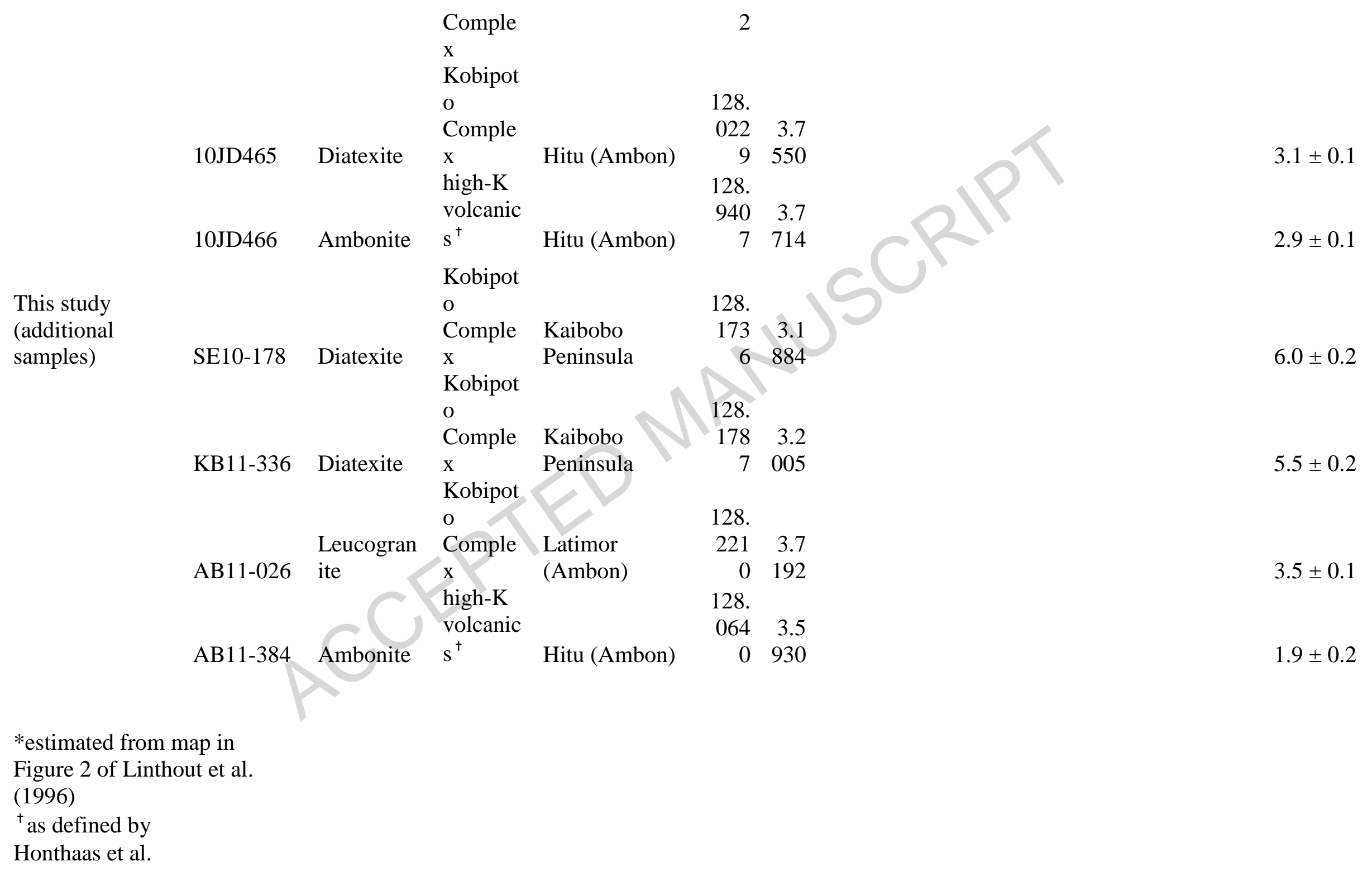


(1999)

w.r.-whole

rock; Gr.-

groundmass

1.s.h.--laser step heating; f.s.h.-_urnace

step heating; 1.s.f.--laser single fusion 
Table 2

\begin{tabular}{|c|c|c|c|c|c|c|c|c|c|c|c|c|c|c|}
\hline & Resid & lual Granı & ulites & & & & & Diatexites & & & & $\begin{array}{l}\text { Leucogr } \\
\text { anite }\end{array}$ & Ambo & nites \\
\hline $\begin{array}{l}\text { Sample } \\
\text { Lat. } \\
\text { Long. }\end{array}$ & $\begin{array}{l}\text { KP11- } \\
588\end{array}$ & $\begin{array}{l}\text { KP11- } \\
619\end{array}$ & $\begin{array}{l}\text { KP12- } \\
133\end{array}$ & $\begin{array}{l}\text { KP11- } \\
621\end{array}$ & $\begin{array}{l}\text { KP11- } \\
624\end{array}$ & $\begin{array}{l}\text { SE10- } \\
178\end{array}$ & $\begin{array}{l}\text { KB11- } \\
218\end{array}$ & $\begin{array}{l}\text { KB11- } \\
336 A\end{array}$ & $\begin{array}{l}\text { KB11- } \\
367\end{array}$ & $\begin{array}{l}\text { AB11- } \\
100\end{array}$ & $\begin{array}{l}\text { AM10- } \\
167\end{array}$ & $\begin{array}{l}\text { AB11- } \\
026\end{array}$ & $\begin{array}{l}\text { AB11- } \\
384\end{array}$ & $\begin{array}{l}\text { SE10 } \\
-8 B\end{array}$ \\
\hline$w t . \%$ & & & & & & & & & & & & & & \\
\hline $\mathrm{SiO}_{2}$ & 49.48 & 56.08 & 69.49 & 65.93 & 57.30 & 73.05 & 71.48 & 73.93 & 75.42 & 69.73 & 75.96 & 77.73 & 67.00 & 66.51 \\
\hline $\mathrm{Al}_{2} \mathrm{O}_{3}$ & 28.07 & 19.86 & 12.77 & 17.65 & 22.07 & 13.75 & 14.78 & 13.87 & 13.27 & 15.67 & 13.70 & 14.41 & 16.03 & 15.26 \\
\hline $\mathrm{Fe}_{2} \mathrm{O}_{3}{ }^{*}$ & 13.25 & 10.22 & 7.08 & 6.19 & 9.63 & 4.02 & 5.05 & 3.81 & 3.44 & 4.23 & 1.21 & 0.32 & 5.00 & 5.06 \\
\hline $\mathrm{MgO}$ & 3.70 & 4.56 & 1.92 & 1.91 & 2.87 & 1.12 & 1.36 & 0.99 & 1.24 & 1.56 & 0.16 & 0.17 & 2.37 & 3.18 \\
\hline $\mathrm{CaO}$ & 1.12 & 3.12 & 0.60 & 1.45 & 1.36 & 1.51 & 2.03 & 1.36 & 1.66 & 1.86 & 0.59 & 0.50 & 3.64 & 3.80 \\
\hline $\mathrm{Na}_{2} \mathrm{O}$ & 0.57 & 1.57 & 1.16 & 1.62 & 1.28 & 2.02 & 1.37 & 1.96 & 2.34 & 2.34 & 3.27 & 4.20 & 2.19 & 2.21 \\
\hline $\mathrm{K}_{2} \mathrm{O}$ & 0.92 & 2.23 & 2.43 & 3.45 & 3.15 & 2.90 & 2.76 & 2.97 & 2.64 & 3.14 & 4.49 & 1.44 & 2.84 & 2.85 \\
\hline $\mathrm{TIO}_{2}$ & 1.73 & 1.12 & 0.55 & 0.73 & 1.15 & 0.57 & 0.65 & 0.57 & 0.52 & 0.55 & 0.09 & 0.12 & 0.59 & 0.54 \\
\hline $\mathrm{MnO}$ & 0.56 & 0.27 & 2.39 & 0.22 & 0.35 & 0.08 & 0.12 & 0.07 & 0.05 & 0.08 & 0.06 & 0.01 & 0.09 & 0.09 \\
\hline $\mathrm{P}_{2} \mathrm{O}_{5}$ & 0.03 & 0.06 & 0.16 & 0.10 & 0.07 & 0.08 & 0.09 & 0.08 & 0.07 & 0.09 & 0.11 & 0.02 & 0.12 & 0.10 \\
\hline $\mathrm{SO}_{3}$ & 0.06 & 0.10 & 0.07 & 0.05 & 0.04 & 0.01 & 0.01 & 0.03 & $\begin{array}{r}0.01 \\
100.6\end{array}$ & 0.01 & 0.03 & 0.01 & 0.01 & 0.01 \\
\hline Total & 99.49 & 99.20 & 98.62 & 99.29 & 99.27 & 99.11 & 99.68 & 99.64 & 5 & 99.26 & 99.66 & 98.92 & 99.88 & 99.61 \\
\hline LOI & 0.99 & 3.59 & 2.31 & 2.90 & 3.99 & 1.13 & 1.86 & 1.76 & 1.81 & 2.07 & 7.56 & 1.71 & 2.44 & 1.44 \\
\hline
\end{tabular}

ppm 


\begin{tabular}{|c|c|c|c|c|c|c|c|c|c|c|c|c|c|c|}
\hline $\mathrm{Ni}$ & 83.4 & 62.2 & 60.1 & 31.8 & 50.5 & 20.6 & 25.5 & 18.8 & 20.5 & 29.4 & 4.3 & 3.6 & 20.5 & 20.1 \\
\hline Co & 31.5 & 31.5 & 22.9 & 19.5 & 28.4 & 9.2 & 11.6 & 11.6 & 20.9 & 3.6 & 5.9 & 4.1 & 21.9 & 22.3 \\
\hline $\mathrm{Cr}$ & 176.0 & 159.0 & 45.4 & 70.9 & 101.7 & 34.8 & 46.6 & 38.2 & 27.2 & 57.2 & 3.4 & 6.2 & 63.5 & 62.3 \\
\hline V & 295.1 & 246.2 & 96.3 & 131.0 & 225.5 & 80.1 & 104.6 & 80.7 & 82.8 & 78.3 & 5.3 & 10.5 & 96.3 & 95.0 \\
\hline Sc & 29.5 & 32.4 & 6.0 & 18.2 & 25.7 & 13.2 & 15.1 & 14.2 & 13.9 & 15.9 & 5.5 & 6.8 & 16.0 & 14.6 \\
\hline $\mathrm{Cu}$ & 116.2 & 112.4 & 120.9 & 60.3 & 112.2 & 21.8 & 27.0 & 23.0 & 19.0 & 13.5 & 2.7 & 7.0 & 24.3 & 23.9 \\
\hline $\mathrm{Zn}$ & $\begin{array}{l}120.0 \\
5313 .\end{array}$ & $\begin{array}{l}109.3 \\
7189 .\end{array}$ & $\begin{array}{r}86.7 \\
16075\end{array}$ & $\begin{array}{r}98.4 \\
4713 .\end{array}$ & $\begin{array}{l}126.1 \\
6083 .\end{array}$ & $\begin{array}{r}57.7 \\
1661 .\end{array}$ & $\begin{array}{r}76.5 \\
1167 .\end{array}$ & 66.1 & 46.6 & 45.5 & 13.9 & 56.1 & 67.4 & 67.7 \\
\hline$S$ & 2 & 7 & .5 & 3 & 9 & 8 & 1 & 1068.1 & 200.3 & 240.2 & 53.5 & 100.9 & 144.8 & 42.9 \\
\hline $\mathrm{F}$ & 126.1 & 643.6 & 295.9 & 673.9 & 525.8 & 483.6 & 619.8 & 593.4 & 564.4 & 552.1 & 357.4 & 190.2 & 454.8 & 45.1 \\
\hline $\mathrm{Cl}$ & 79.2 & 285.3 & 134.1 & 251.0 & 409.2 & 118.9 & 114.2 & 305.7 & 0 & 206.6 & 81.9 & 277.9 & 525.9 & 504.8 \\
\hline $\mathrm{Ga}$ & 30.4 & 23.6 & 16.8 & 21.1 & 28.0 & 15.5 & 17.2 & 15.8 & 14.2 & 18.1 & 14.6 & 12.7 & 18.7 & 18.8 \\
\hline $\mathrm{Pb}$ & 2.1 & 11.4 & 20.3 & 26.8 & 12.8 & 20.3 & 21.6 & 21.0 & 18.6 & 24.8 & 36.9 & 12.5 & 24.5 & 24.7 \\
\hline $\mathrm{Sr}$ & 58.2 & 162.7 & 57.4 & 122.4 & 117.4 & 107.0 & 122.4 & 105.1 & 80.7 & 115.8 & 25.2 & 113.0 & 187.0 & 187.1 \\
\hline $\mathrm{Rb}$ & 25.9 & 83.7 & 88.2 & 139.0 & 135.1 & 125.3 & 107.3 & 128.3 & 110.5 & 140.1 & 228.0 & 80.0 & 136.6 & 136.3 \\
\hline $\mathrm{Ba}$ & 131.4 & 654.2 & 645.8 & 458.6 & 530.4 & 402.4 & 392.7 & 621.0 & 354.9 & 479.2 & 255.6 & 129.6 & 566.0 & 565.2 \\
\hline $\mathrm{Zr}$ & 363.0 & 205.7 & 140.8 & 165.5 & 254.3 & 176.4 & 162.1 & 170.5 & 156.0 & 163.8 & 57.9 & 48.8 & 161.1 & 161.0 \\
\hline $\mathrm{Nb}$ & 32.5 & 16.2 & 27.7 & 16.0 & 23.7 & 10.5 & 11.9 & 10.2 & 8.4 & 12.2 & 6.4 & 6.4 & 15.2 & 15.2 \\
\hline $\mathrm{Ta}$ & 2.4 & 0.5 & 2.8 & 1.5 & 1.3 & 1.5 & 1.2 & 1.5 & 1.1 & 1.6 & 1.6 & 2.4 & 1.3 & 1.2 \\
\hline Mo & 6.6 & 3.6 & 7.2 & 9.6 & 3.2 & 0.5 & 0.9 & 0.5 & 0.2 & 0.4 & 0.1 & -0.1 & 1.2 & 0.8 \\
\hline Th & 16.3 & 21.2 & 11.6 & 14.9 & 19.9 & 11.5 & 12.1 & 11.0 & 8.8 & 15.7 & 6.5 & 6.6 & 13.6 & 13.6 \\
\hline U & 1.1 & 1.4 & 2.9 & 2.1 & 2.4 & 1.7 & 1.4 & 1.6 & 1.1 & 5.0 & 2.3 & 3.1 & 3.3 & 3.3 \\
\hline Y & 59.6 & 52.0 & 21.9 & 30.5 & 40.7 & 24.1 & 31.5 & 24.5 & 23.3 & 30.4 & 26.0 & 25.0 & 29.6 & 29.3 \\
\hline La & 49.9 & 44.2 & 28.3 & 30.0 & 37.4 & 24.7 & 27.9 & 25.8 & 17.1 & 29.3 & 8.3 & 13.1 & 37.1 & 36.8 \\
\hline $\mathrm{Ce}$ & 97.5 & 94.8 & 69.1 & 62.4 & 86.5 & 53.6 & 59.8 & 54.6 & 39.5 & 62.5 & 18.8 & 23.5 & 70.1 & 70.6 \\
\hline $\mathrm{Nd}$ & 39.5 & 38.0 & 23.9 & 27.2 & 33.6 & 23.8 & 26.2 & 24.5 & 16.7 & 25.6 & 8.9 & 12.8 & 32.6 & 32.5 \\
\hline Sm & 7.8 & 8.9 & 2.4 & 5.0 & 6.2 & 6.6 & 7.3 & 5.5 & 4.4 & 6.8 & 3.0 & 4.0 & 6.8 & 5.7 \\
\hline $\mathrm{Yb}$ & 8.6 & 5.2 & 2.9 & 4.4 & 5.0 & 3.0 & 3.4 & 3.0 & 2.8 & 2.9 & 3.3 & 2.7 & 3.4 & 3.5 \\
\hline
\end{tabular}




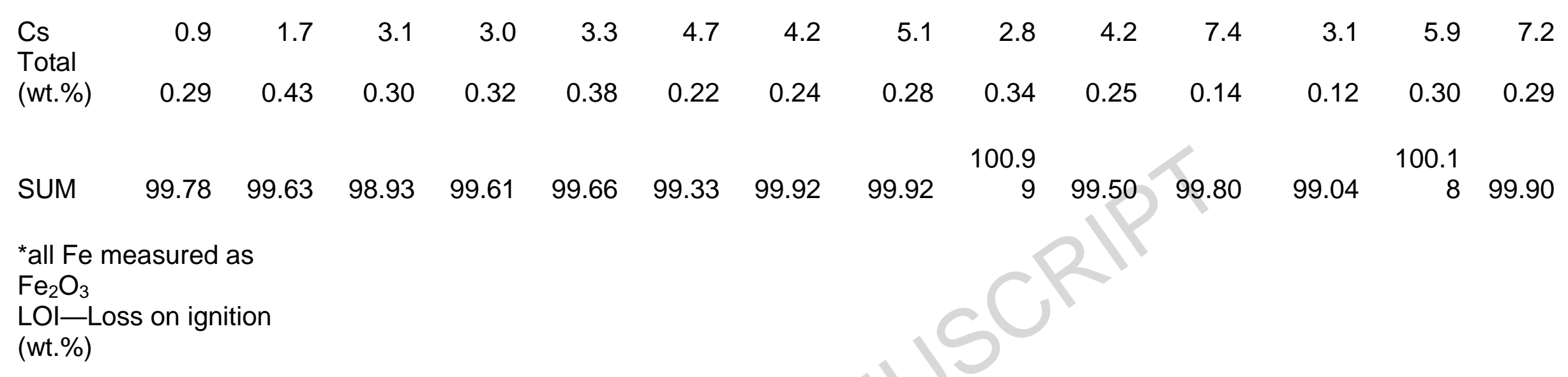


Table 3

\begin{tabular}{|c|c|c|c|c|c|}
\hline \multirow[b]{2}{*}{$\begin{array}{l}\text { Sample } \\
\text { Lat. } \\
\text { Long. }\end{array}$} & \multicolumn{2}{|c|}{ Lherzolites } & \multicolumn{3}{|c|}{ Serpentinites ${ }^{\star \star}$} \\
\hline & KP12-123 & KB11-700 & AB11-018 & KB11-201 & TS11-482 \\
\hline$w t . \%$ & & & & & \\
\hline $\mathrm{SiO}_{2}$ & 46.26 & 44.83 & 45.27 & 46.22 & 43.78 \\
\hline $\mathrm{Al}_{2} \mathrm{O}_{3}$ & 0.96 & 2.22 & 1.10 & 2.50 & 3.17 \\
\hline $\mathrm{Fe}_{2} \mathrm{O}_{3}{ }^{*}$ & 8.77 & 9.19 & 9.75 & 9.28 & 12.43 \\
\hline $\mathrm{MgO}$ & 42.09 & 41.23 & 41.03 & 38.92 & 37.52 \\
\hline $\mathrm{CaO}$ & 0.56 & 1.59 & 1.35 & 1.68 & 1.75 \\
\hline $\mathrm{Na}_{2} \mathrm{O}$ & 0.03 & 0.07 & 0.15 & 8 & 0.10 \\
\hline $\mathrm{K}_{2} \mathrm{O}$ & 0.00 & 0.01 & 0.02 & 0.02 & 0.03 \\
\hline $\begin{array}{l}\mathrm{TlO}_{2} \\
\mathrm{MnO}\end{array}$ & $\begin{array}{l}0.06 \\
0.13\end{array}$ & $\begin{array}{l}0.05 \\
0.13\end{array}$ & $\begin{array}{l}0.04 \\
0.11\end{array}$ & $\begin{array}{l}0.05 \\
0.13\end{array}$ & $\begin{array}{l}0.14 \\
0.09\end{array}$ \\
\hline $\mathrm{P}_{2} \mathrm{O}_{5}$ & 0.00 & 0.00 & 0.01 & 0.01 & 0.01 \\
\hline $\mathrm{SO}_{3}$ & 0.02 & 0.01 & 0.05 & 0.04 & 0.25 \\
\hline Total & 98.90 & 99.33 & 98.85 & 99.02 & 99.28 \\
\hline LOI & 9.32 & 5.49 & 9.99 & 5.42 & 13.22 \\
\hline ppm & & & & & \\
\hline $\mathrm{Ni}$ & 2226.1 & 2338.6 & 2703.4 & 2354.1 & 3080.0 \\
\hline Co & 106.2 & 115.3 & 126.3 & 115.1 & 147.0 \\
\hline
\end{tabular}




$\begin{array}{lrrrrr}\mathrm{Cr} & 2144.7 & 2502.9 & 2145.3 & 2941.2 & 4319.1 \\ \mathrm{~V} & 29.1 & 56.4 & 38.9 & 61.4 & 61.4 \\ \mathrm{Sc} & 7.9 & 12.2 & 8.8 & 13.4 & 11.9 \\ \mathrm{Cu} & 24.1 & 22.0 & 7.3 & 17.1 & 12.6 \\ \mathrm{Zn} & 54.1 & 47.6 & 47.3 & 57.3 & 59.1 \\ \mathrm{~S} & 419.4 & 492.5 & 1182.6 & 1113.5 & 5933.7 \\ \mathrm{~F} & -19.5 & -56.2 & 154.2 & -14.1 & 13.1 \\ \mathrm{Cl} & 758.6 & 675.6 & 9842.2 & 697.5 & 894.5 \\ \mathrm{Ga} & 1.1 & 1.7 & 1.1 & 2.7 & 2.6 \\ \mathrm{~Pb} & 0.0 & 0.7 & 0.7 & 0.7 & 1.3 \\ \mathrm{Sr} & 2.0 & 4.7 & 36.8 & 3.1 & 18.5 \\ \mathrm{Rb} & 0.0 & 0.1 & 0.4 & 1.2 & 1.7 \\ \mathrm{Ba} & 0.6 & 5.8 & 1.5 & 4.3 & 3.9 \\ \mathrm{Zr} & 1.5 & -0.1 & 0.9 & 0.9 & 5.1 \\ \mathrm{Nb} & 0.2 & -0.1 & -0.1 & 0.0 & 0.1 \\ \mathrm{Ta} & 1.2 & 0.3 & 0.8 & 0.8 & -0.1 \\ \mathrm{Mo} & 0.1 & 0.1 & 0.1 & 0.1 & -0.2 \\ \mathrm{Th} & -0.1 & 0.0 & 0.1 & 0.2 & 0.1 \\ \mathrm{U} & 0.1 & -0.3 & 0.1 & -0.3 & -0.3 \\ \mathrm{Y} & 0.8 & 1.4 & 0.3 & 1.5 & 3.2 \\ \mathrm{La} & -0.2 & 0.9 & 0.0 & 0.7 & 1.1 \\ \mathrm{Ce} & 1.5 & -0.9 & -1.6 & -0.6 & 0.3 \\ \mathrm{Nd} & 0.2 & 0.0 & -0.3 & 1.2 & 0.0 \\ \mathrm{Sm} & 0.3 & -0.9 & -0.6 & 0.6 & 0.0 \\ \mathrm{Yb} & 9.6 & 15.8 & 18.0 & 16.0 & 19.9 \\ \mathrm{Cs} & 0.5 & -0.2 & 1.1 & 0.3 & 2.0 \\ \mathrm{Total} & & & & & \\ (\mathrm{wt} . \%) & 0.71 & 0.77 & 1.72 & 0.86 & 1.32 \\ & & & & & \end{array}$




\section{SUM}

99.61

100.10

100.58

99.88

100.60

*all Fe measured as $\mathrm{Fe}_{2} \mathrm{O}_{3}$

**after lherzolite

LOI-Loss on ignition (wt.\%) 


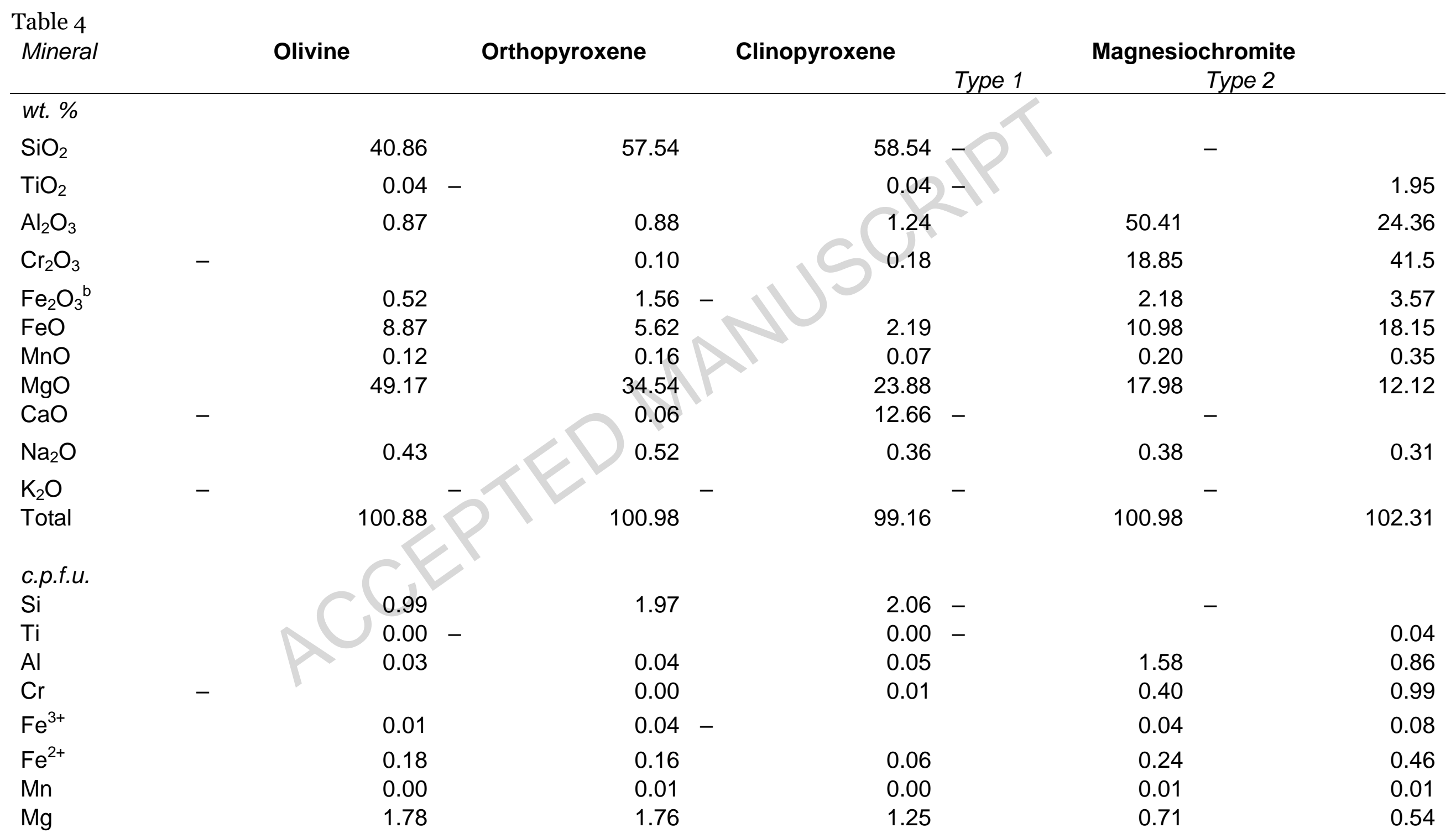




\begin{tabular}{|c|c|c|c|c|c|c|}
\hline $\mathrm{Ca}$ & - & & 0.00 & 0.48 & & \\
\hline $\mathrm{Na}$ & & 0.02 & 0.03 & 0.03 & 0.02 & 0.02 \\
\hline $\mathrm{K}$ & - & & 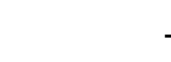 & 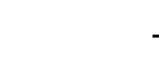 & & \\
\hline Sum & & 3.00 & 4.01 & 3.93 & 3.00 & 3.00 \\
\hline Oxygens & & 4 & 6 & 6 & 4 & 4 \\
\hline$X_{\mathrm{Fe} 3+}$ & & 0.05 & 0.20 & 0.00 & 0.15 & \\
\hline $\begin{array}{l}\text { Mg\# } \\
\text { Cr\# }\end{array}$ & - & 90.38 & $\begin{array}{r}89.76 \\
7.89\end{array}$ & $\begin{array}{r}95.13 \\
8.93\end{array}$ & $\begin{array}{l}71.20 \\
20.04\end{array}$ & $\begin{array}{l}50.28 \\
53.33\end{array}$ \\
\hline
\end{tabular}




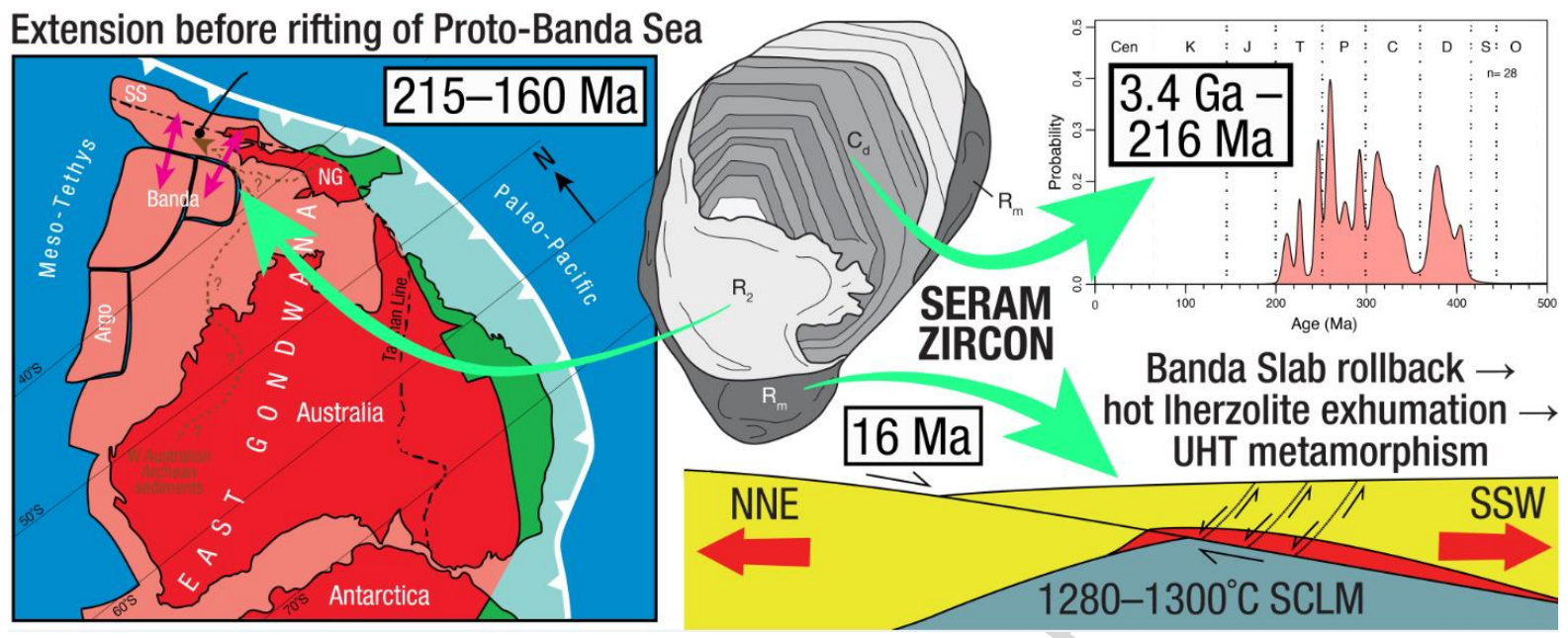

Graphical abstract 


\section{Highlights}

- UHT metamorphism and melting occurred at $16 \mathrm{Ma}$ in response to mantle exhumation

- Lherzolites were juxtaposed against UHT migmatites on Seram while at $1280-1300^{\circ} \mathrm{C}$

- Australia-SE Asia collision is recorded on Seram at 24-20 Ma

- A Late Triassic-Early Jurassic metamorphic/magmatic event occurred also on Seram

- Ambonite volcanism (3-2 Ma) was fed primarily from the Kobipoto migmatite complex 